\title{
ANÁLISE DOS PLANOS DE DESENVOLVIMENTO ELABORADOS NO BRASIL APÓS O II PND
}

\author{
PATRÍCIA DE OLIVEIRA MATOS
}

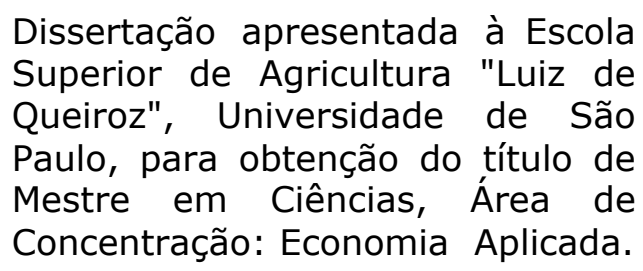

\author{
P I R A C I C A B A \\ Estado de São Paulo - Brasil \\ Outubro - 2002
}




\title{
ANÁLISE DOS PLANOS DE DESENVOLVIMENTO ELABORADOS NO BRASIL APÓS O II PND
}

\author{
PATRÍCIA DE OLIVEIRA MATOS
}

Bacharel em Ciências Econômicas

Orientador: Prof.Dr. PEDRO CARVALHO DE MELLO

Dissertação apresentada à Escola Superior de Agricultura "Luiz de Queiroz", Universidade de São Paulo, para obtenção do título de Mestre em Ciências, Área de Concentração: Economia Aplicada.

\author{
P I R A C I C A B A \\ Estado de São Paulo - Brasil \\ Outubro - 2002
}




\section{Dados Internacionais de Catalogação na Publicação (CIP)} DIVISÃO DE BIBLIOTECA E DOCUMENTAÇÃO - ESALQ/USP

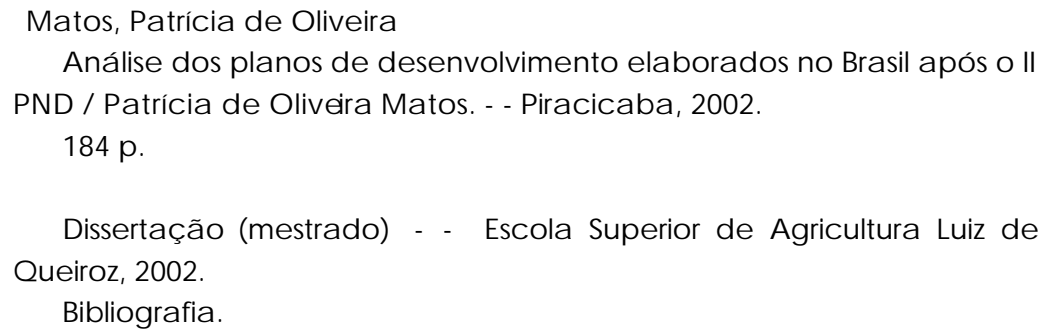

1. Aná lise ec onômica 2. Bra sil 3. Ind ic ador sóc io-ec onômico 4.

Planejamento econômico 5. Plano Nacional de Desenvolvimento I. Título

CDD 338.9

"Permitida a cópia total ou parcial deste documento, desde que citada a fonte - $O$ autor" 
Aos meus pais e irmãos. 


\section{AGRADECIMENTOS}

Ao orientador Pedro Carvalho de Mello pelo incentivo ao estudo da economia brasileira e do tema planejamento econômico.

Aos funcionários do Departamento de Economia da ESALQ, principalmente à Maiélli, pelos esclarecimentos, paciência e carinho dedicados aos estudantes.

Aos professores Alexandre Mendonça de Barros, Heloísa Lee Burninsk e Márcia Azanha por instigarem questões que em muito contribuíram para o aperfeiçoamento da pesquisa.

Ao professor Paulo Cidade de Araújo pelo aprendizado sobre o desenvolvimento econômico e pelas leituras do pensamento cepalino.

Aos colegas de curso: Cristiane, Cíntia, Valeriana, Goncílio, Jaenes e Cândida pelas pousadas, caronas e informações, mas sobretudo pelo riso e amizade sempre presentes.

À Academia da Força Aérea (AFA) pelas dispensas concedidas que possibilitaram a realização do Mestrado.

Aos coordenadores Júlio Cabianca, Salomão e Rosângela, pelo apoio em diversas ocasiões. 
Aos colegas e amigos da AFA, principalmente das áreas III e IV e da SIAVI, por tornarem mais agradável o ambiente da academia.

Ao Moisés, que mesmo distante, manteve a amizade e as discussões "filosóficas" que sempre contribuíram para o meu crescimento pessoal e profissional.

À Cláudia, pelo companheirismo e apoio (mesmo durante as crises).

Ao Veiga, fonte de inspiração e de alegria, pela presença.

À minha "grande família" por tudo. 


\section{SUMÁRIO}

Página

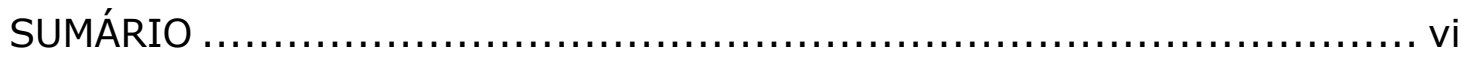

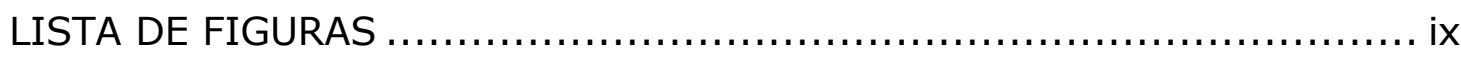

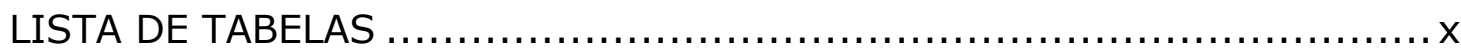

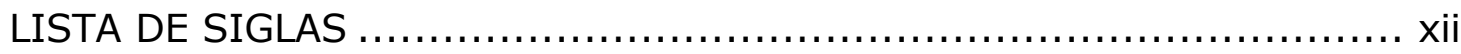

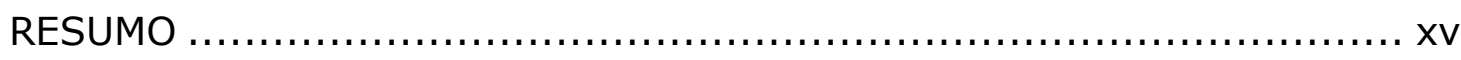

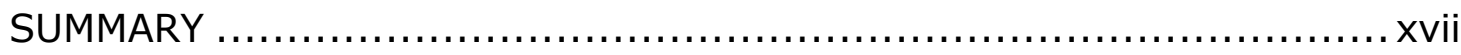

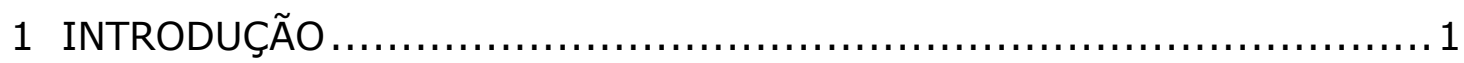

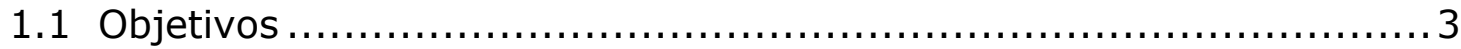

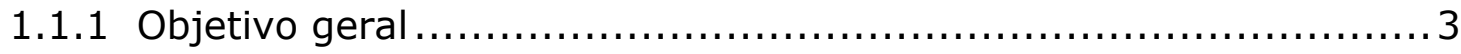

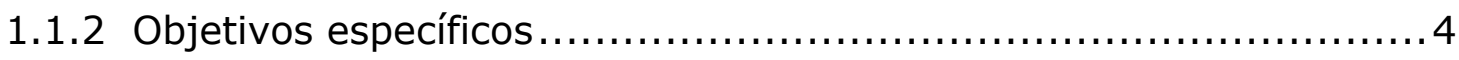

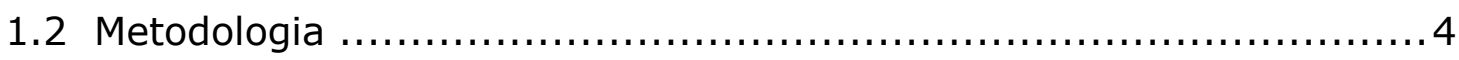

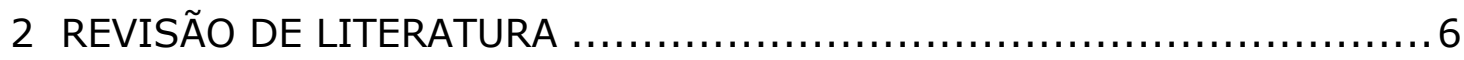

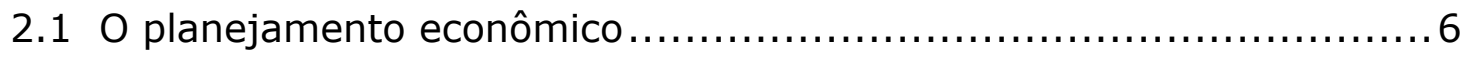

2.1.1 A controvérsia do planejamento econômico $\ldots \ldots \ldots \ldots \ldots \ldots \ldots \ldots \ldots \ldots \ldots$

2.1.2 Os problemas de programação do setor público $\ldots \ldots \ldots \ldots \ldots \ldots \ldots \ldots \ldots \ldots$

2.2 O Sistema de Planejamento Integrado .............................. 19

2.3 A experiência brasileira de planejamento ........................... 24

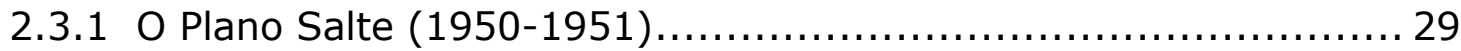

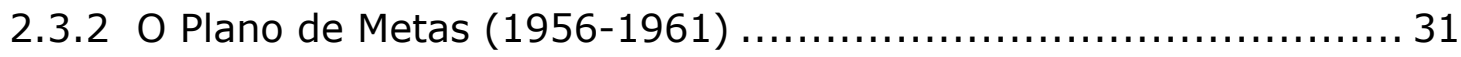

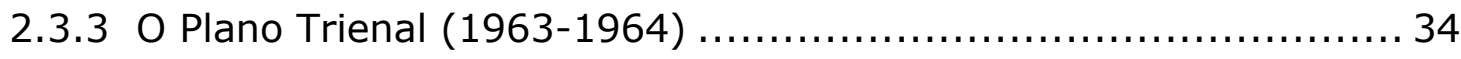

2.3.4 O Plano de Ação Econômica do Governo (1964-1967)............... 37

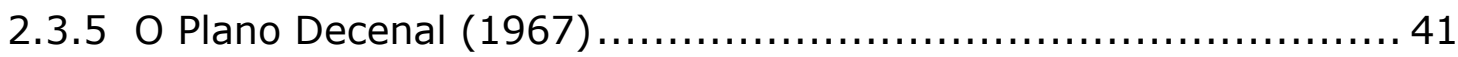


2.3.6 O primeiro Orçamento Plurianual de Investimentos (1968-1970).. 42

2.3.7 O Programa Estratégico de Desenvolvimento (1968-1970) ......... 43

2.3.8 O Plano Metas e Bases Para a Ação do Governo (1970-1973) ...... 45

2.3.9 O primeiro Plano Nacional de Desenvolvimento (1972-1974) ...... 46

2.3.10 O segundo Plano Nacional de Desenvolvimento (1975-1979) ..... 50

2.3.11 O planejamento regional no Brasil ................................. 53

2.4 A crise do planejamento no Brasil ..................................... 56

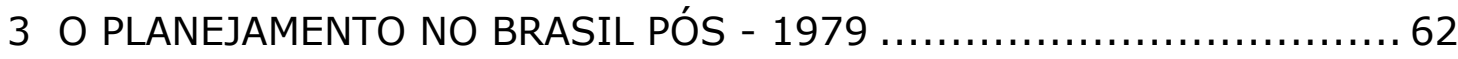

3.1 Os planos de desenvolvimento após o II PND..........................6 68

3.1.1 O terceiro Plano Nacional de Desenvolvimento (1980 - 1985) ......69

3.1.2 O primeiro Plano Nacional de Desenvolvimento da Nova República

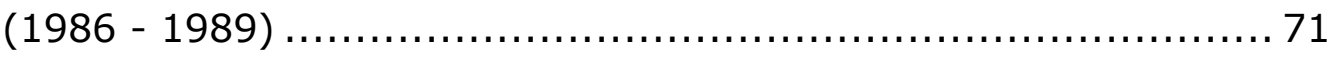

3.1.3 O Plano de Ação Governamental (1987-1991) ..................... 73

$3.2 \mathrm{O}$ novo modelo de planejamento - os planos plurianuais ............... 75

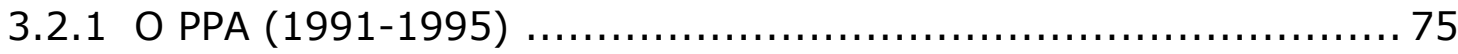

3.2.2 O PPA (1996-1999) - Brasil em Ação .................................. 79

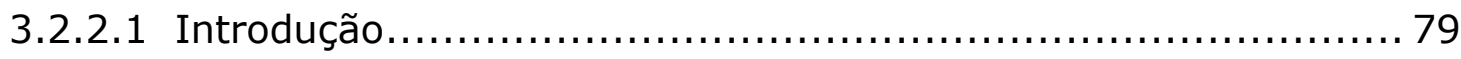

3.2.2.2 Contexto macroeconômico ........................................ 81

3.2.2.3 Investimentos e ação governamental ............................. 84

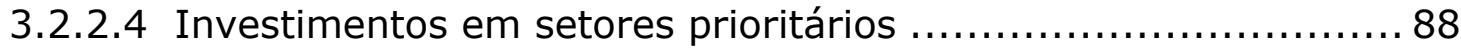

3.2.2.5 PPA-96 - Avaliação.................................................. 94

3.2.3 O PPA (2000-2003) - Avança Brasil ................................... 99

3.2.3.1 Introdução........................................................ 99

3.2.3.2 Contexto macroeconômico ....................................... 100

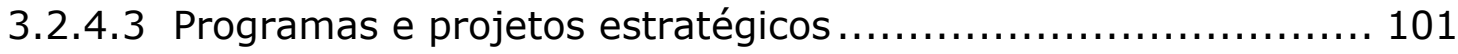

3.2.3.4 O Programa Gestão Pública Empreendedora ...................... 104

3.2.3.5 PPA 2000 - Inovações e críticas................................. 105

3.2.3.6 Avaliação do cenário macroeconômico e dos programas implementados .................................................... 109

4 EVOLUÇÃO DE INDICADORES E A ECONOMIA BRASILEIRA ............. 114 
4.1 Panorama geral da economia brasileira ............................. 115

4.2 Indicadores e planos de desenvolvimento........................... 117

4.2 .1 Indicadores da produção............................................ 117

4.2.1.1 O produto interno bruto e a renda per capita .................... 117

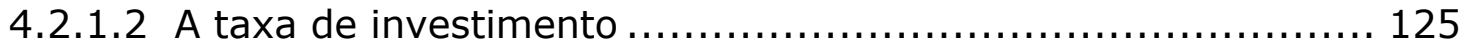

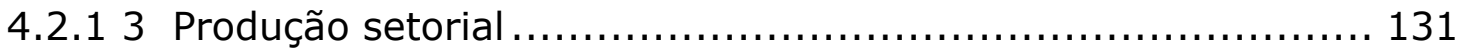

4.2.1.4 O nível de emprego ............................................ 140

4.2.2 Indicadores macroeconômicos ..................................... 146

4.2.2.1 Inflação............................................................ 146

4.2.2.2 Dívida externa..................................................... 150

4.2.2.3 Dívida interna .................................................. 156

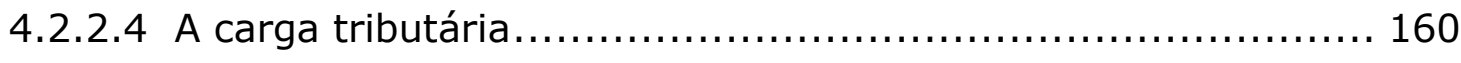

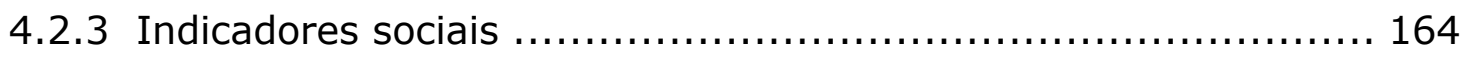

4.2.3.1 Salário mínimo e distribuição de renda .............................. 164

4.2.3.2 O Índice de Desenvolvimento Humano (IDH) .................... 169

4.2 .3 .3 Indicador de pobreza............................................. 172

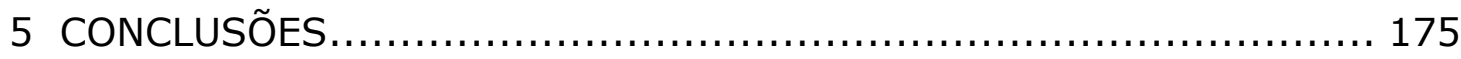

REFERÊNCIAS BIBLIOGRÁFICAS ..................................... 179 


\section{LISTA DE FIGURAS}

Página

1 Taxa de crescimento do PIB 1950-2000 ...............................121

2 Taxa de crescimento da renda per capita 1950 - 2000 ...................121

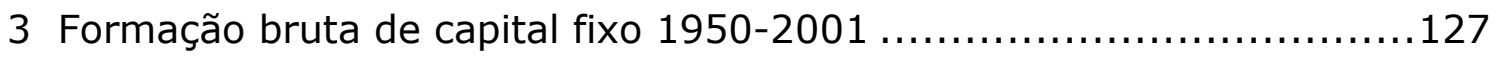

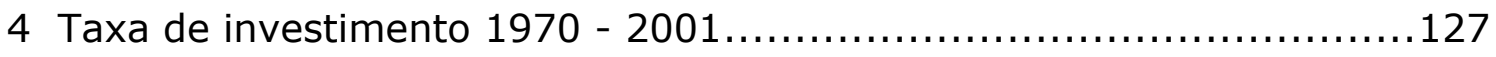

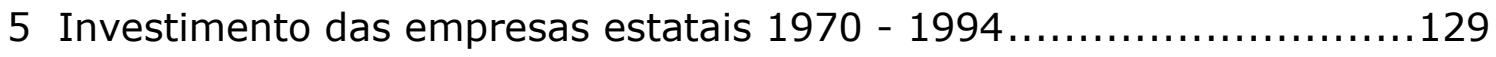

6 Variação da produção setorial 1971-1996 ...............................136

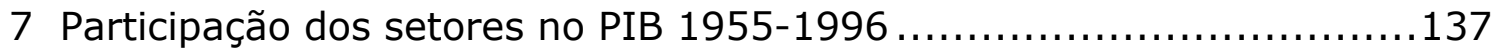

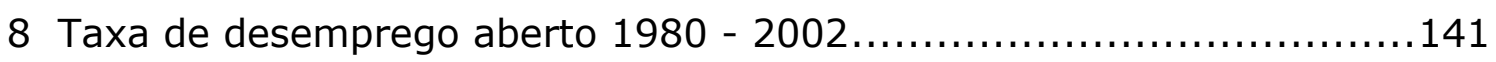

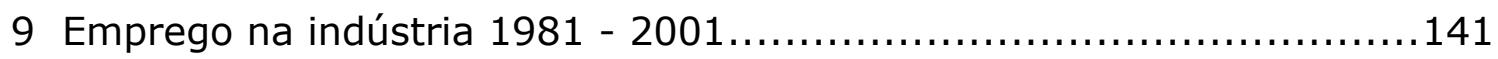

10 Produtividade da mão-de-obra 1991-1999 ............................143

11 Produtividade da indústria de transformação $1982-2001 \ldots \ldots \ldots \ldots \ldots . \ldots 143$

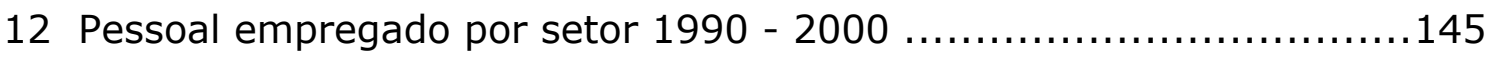

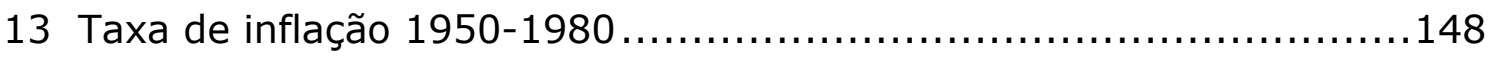

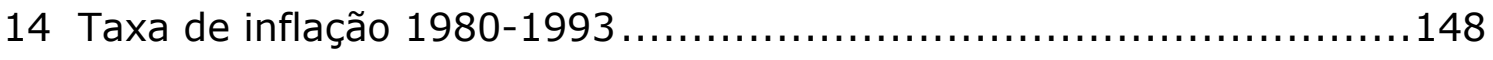

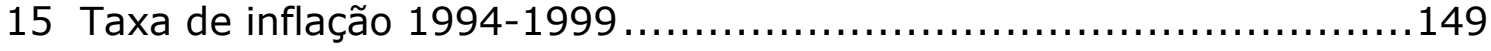

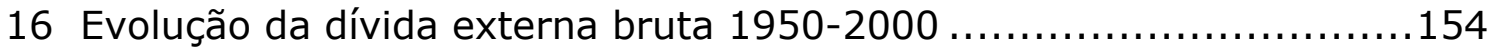

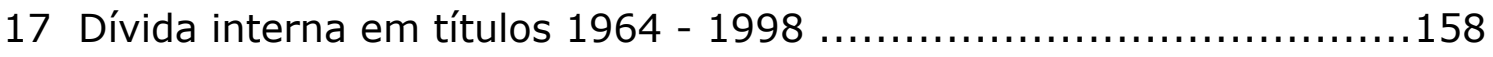

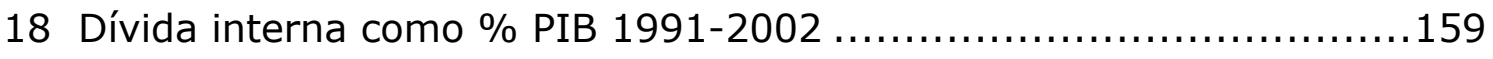

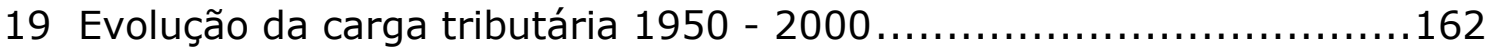

20 Evolução do salário mínimo real 1950 - 2002 ..........................166

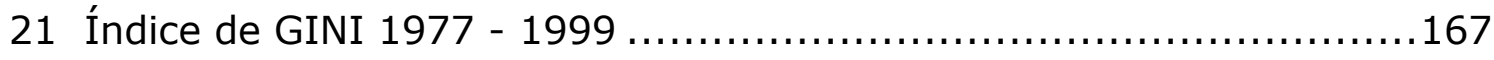

22 Índice de Desenvolvimento Humano 1970 - 1996 .......................171

23 Índice de esperança de vida..........................................171

24 Índice de educação...................................................... 171

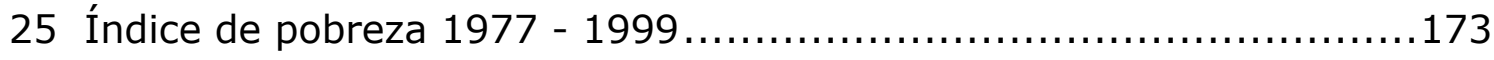




\section{LISTA DE TABELAS}

Página

1 Plano de Metas - previsão e resultados (1957-1961)..................... 34

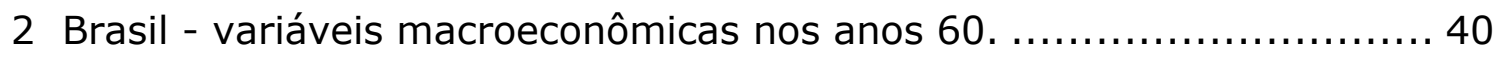

3 Milagre Econômico - resultados macroeconômicos........................ 45

4 Resultados macroeconômicos durante o II PND........................... 53

5 Brasil - dados macroeconômicos (1979-1989). .............................. 61

6 Obras inacabadas. ...................................................... 78

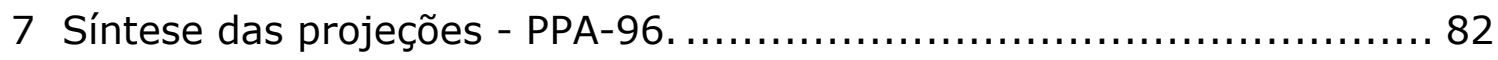

8 Fontes de financiamento do investimento. .............................. 83

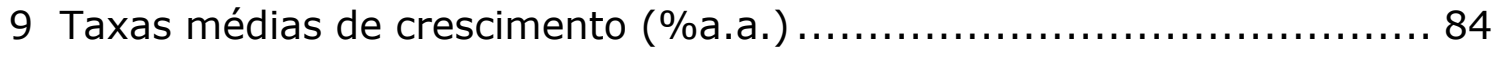

10 Investimentos e custeio. ............................................. 85

11 Fontes de Financiamento (R\$ Milhões) ................................ 86

12 1999_Cenário único e estimativas recentes. ............................ 95

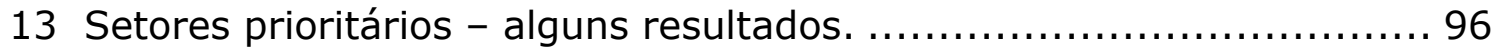

14 Execução orçamentário financeira por subprogramas $\ldots \ldots \ldots \ldots \ldots \ldots \ldots . \ldots 7$

15 Programas estratégicos - PPA-2000................................... 102

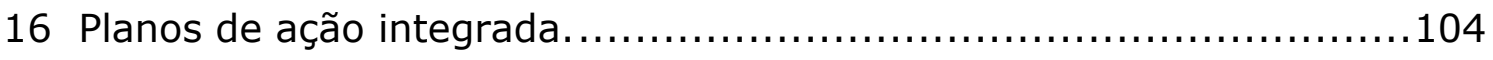

17 Cenário macroeconômico PPA-2000: projetado e realizado...............112

18 Resultados e realização física dos programas do PPA-2000.............113

19 Planos de desenvolvimento e PIB .................................... 122

20 Planos de desenvolvimento e renda per capita ..........................123

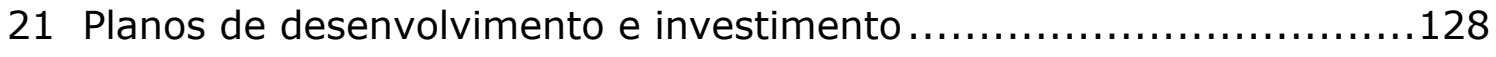

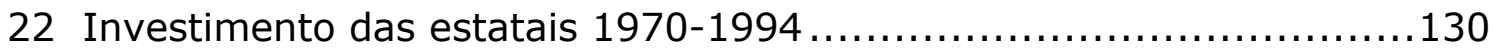

23 Variação da produção por setores ......................................137

24 Participação dos setores no PIB ........................................ 139 
25 Planos de desenvolvimento e nível de emprego

26 Produtividade da indústria de transformação e da mão-de-obra ........144

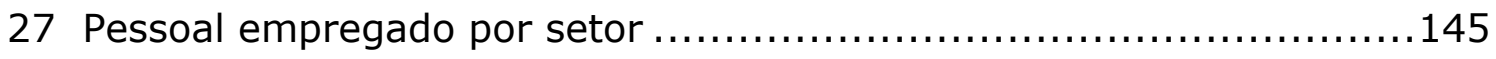

28 Planos de desenvolvimento e inflação ....................................149

29 Planos de desenvolvimento e dívida externa ...........................154

30 Planos de desenvolvimento e dívida interna............................159

31 Planos de desenvolvimento e carga tributária ...........................163

32 Planos de desenvolvimento e a evolução do salário mínimo..............167

33 Planos de desenvolvimento e distribuição de renda $\ldots \ldots \ldots \ldots \ldots \ldots \ldots \ldots \ldots$

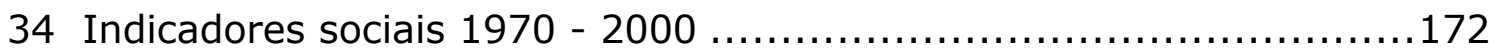

35 Planos de desenvolvimento e índice de pobreza.......................174 


\section{LISTA DE SIGLAS}

BID - Banco Interamericano de Desenvolvimento

BNB - Banco do Nordeste do Brasil

BNDE - Banco Nacional de Desenvolvimento Econômico

BNDES - Banco Nacional de Desenvolvimento Econômico e Social

BNH - Banco Nacional de Habitação

C\&T - Ciência e Tecnologia

CDE - Conselho de Desenvolvimento Econômico

CEPAL - Comissão Econômica Para a América Latina

CODEVASF - Companhia de Desenvolvimento do Vale do São Francisco

COPLAN - Comissão Nacional de Planejamento

ENAP - Escola Nacional de Administração Pública

FBCF - Formação Bruta de Capital Fixo

FGTS - Fundo de Garantia por Tempo de Serviço

FINAM - Fundos de Investimento da Amazônia

FINOR - Fundos de Investimento do Nordeste

FNDE - Fundo Nacional de Desenvolvimento

GTDN - Grupo de Trabalho para o Desenvolvimento do Nordeste

GTI - Grupo de Trabalho Interministerial

IGP-DI - Índice Geral de Preços - Disponibilidade Interna

IPEA - Instituto de Pesquisa Econômica Aplicada

IPMF - Imposto Provisório sobre Movimentação Financeira

LDO - Lei de Diretrizes Orçamentárias

LOA - Lei de Orçamentos Anuais

MBAG - Metas e Bases para a Ação do Governo 
MEFP - Ministério da Economia da Fazenda e do Planejamento

MPO - Ministério do Planejamento Orçamento e Gestão

NFSP - Necessidade de Financiamento do Setor Público

ONU - Organização das Nações Unidas

OPI - Orçamento Plurianual de Investimentos

ORTN - Obrigações Reajustáveis do Tesouro Nacional

PAEG - Plano de Ação Econômica do Governo

PAG - Plano de Ação Governamental

PASEP - Programa de Apoio ao Servidor Público

PCM - Plano de Consistência Macroeconômica

PDR - Plano de Desenvolvimento Regional

PEA - População Economicamente Ativa

PED - Programa Estratégico de Desenvolvimento

PGPE - Programa Gestão Pública Empreendedora

PIB - Produto Interno Bruto

PIN - Programa de Integração Nacional

PIS - Programa de Integração Social

PND - Plano Nacional de Desenvolvimento

I PND - Primeiro Plano Nacional de Desenvolvimento

I PND-NR - Primeiro Plano Nacional de Desenvolvimento da Nova República

II PND - Segundo Plano Nacional de Desenvolvimento

III PND - Terceiro Plano Nacional de Desenvolvimento

PNUD - Programa das Nações Unidas para o Desenvolvimento

POLOAMAZÔNIA - Programa de Desenvolvimento de Áreas Integradas da Amazônia

POLONORDESTE - Programa de Desenvolvimento de Áreas Integradas do Nordeste

PPA - Plano Plurianual de Investimentos

PROAGRO - Programa de Garantia da Atividade Agropecuária

PRODETUR - Programa de Desenvolvimento da Infra-Estrutura Turística do Nordeste 
PRONAF - Programa Nacional de Agricultura Familiar

PROTERRA - Programa de Redistribuição de Terras ao Nordeste SEPLAN - Secretaria de Planejamento

SEPLAN-PR - Secretaria de Planejamento e Coordenação da Presidência da República

SUDAM - Superintendência para o Desenvolvimento da Amazônia SUDECO - Superintendência para o Desenvolvimento do Centro-Oeste SUDENE - Superintendência para o Desenvolvimento do Nordeste SUDESUL - Superintendência para o Desenvolvimento da Fronteira Sudoeste

SUVALE - Superintendência do Desenvolvimento do Vale do São Francisco 


\title{
ANÁLISE dOS PLANOS DE DESENVOLVIMENTO ELABORADOS NO BRASIL APÓS O II PND
}

\author{
Autor: PATRÍCIA DE OLIVEIRA MATOS \\ Orientador: Prof.Dr. PEDRO CARVALHO DE MELLO
}

\section{RESUMO}

O presente trabalho busca analisar a trajetória do planejamento econômico no Brasil, enfatizando os planos de desenvolvimento elaborados após o II PND. Para isto divide-se em quatro partes: primeiramente, observa-se a evolução do planejamento no país até 1979, com a descrição dos planos até o II PND e da crise do planejamento a partir dos anos 80; na segunda e terceira parte, procura-se identificar, descrever e analisar os planos de desenvolvimento do país após o II PND; e, por último, analisa-se a evolução de indicadores econômicos e sociais durante as fases de implementação dos planos de desenvolvimento. Na primeira fase da pesquisa constata-se o aprofundamento do processo de planejamento no Brasil desde o Plano Salte até o II PND. Como resultado deste processo, o país pôde estruturar a sua cadeia produtiva e avançar para indústrias de alta tecnologia. No entanto, a partir do final da década de 70 , esta prática governamental se esgotou diante da crise fiscal do Estado e da descrença na capacidade de planejamento do setor público, dado o relativo insucesso do 
II PND. Na segunda e terceira parte do trabalho, foram identificados os seguintes planos de desenvolvimento: o III PND, o I PND-NR, O PAG, o PPA91, o PPA-96 e o PPA-2000. Observa-se que, no período que se iniciou com - III PND, e que perdurou durante praticamente toda a década de 90, prevaleceu a falência do planejamento no Brasil e um profundo descrédito quanto ao seu potencial. Com a Constituição de 1988, ficou estabelecido o modelo de planejamento baseado nos planos plurianuais. No entanto, o primeiro PPA, O PPA-91, não pode ser considerado como instrumento para estimular o desenvolvimento, uma vez que foi criado apenas para cumprir o preceito constitucional e praticamente não foi implementado. A partir do segundo PPA, O PPA-96, percebe-se uma tentativa para a retomada do planejamento no âmbito da administração pública federal. Do primeiro PPA, de 1991, ao Avança Brasil, de 2000, que usa o modelo de gerenciamento na execução dos programas, nota-se um esforço maior para o aprimoramento na implementação e no alcance de objetivos. Na última parte do trabalho, considera-se a evolução de indicadores sócio-econômicos nas fases de implementação dos planos de desenvolvimento dos últimos 50 anos. Observa-se que a efetivação da política de desenvolvimento não só causa impactos sobre os indicadores selecionados, como também é afetada por eles. 


\title{
AN ANALYSIS OF THE DEVELOPMENT PLANS IN BRAZIL AFTER THE II PND
}

\author{
Author: PATRÍCIA DE OLIVEIRA MATOS \\ Adviser: Prof. Ph.D. PEDRO CARVALHO DE MELLO
}

\section{SUMMARY}

The present study's aim is to analyze the history of Brazil's economical plan, emphasizing the development plans that came about after the II PND. For this purpose, it is divided in four parts: firstly, the plan's evolution in the country up to 1979 should be observed, describing the plans up to the II PND and the crisis that started in the 80s; in the second and third part, the study identifies, describes and analyses the development plans in the country after the II PND; and, finally, it analyzes the evolution of the economical and social indicators during the implement of the development plans. In the first stage of the research it was found that there was an intensification of the planning process in Brazil from plan Salte up to the II PND. As a result of this process, the country was able to establish its industrial production and move forward to high-tech industries. However, from the late $70 \mathrm{~s}$ on, this governmental practice came to an end due to the public debt crisis and distrust on the government's capacity caused by the II PND's failure. In the second and third part of the research the following development plans were identified: the III PND, PND-NR, PAG, PPA-91, PPA- 
96 and PPA-2000. It can be observed that in the period that began with the III PND and lasted throughout the 90s, the breakdown of Brazil's planning and a deep lack of faith in its potential prevailed. In the 1988 Constitution it was established the planning model based on pluri-annual plans. However, the first PPA, PPA-91, can't be considered a tool to encourage development because it was created just for the Constitution and practically wasn't implemented. From the second PPA, PPA-96, it can be noticed that there's an effort to resume the planning in public administration. From the first PPA, in 1991, to Avança Brasil (2000) that used the managing model for programs, the plan becomes more valued and there's a greater effort to set and achieve goals. In the last part of the study it can be observed the evolution of the social and economical indicators in the implementing stages of the development plans in the last 50 years. It can also be observed that not only does the development policy affects the selected indicators but it is also affected by them. 


\section{INTRODUÇÃO}

Há mais de vinte anos, o tema planejamento econômico para o desenvolvimento tem sido relegado no Brasil. A partir da década de 80 e das sucessivas crises associadas a um processo inflacionário crônico e de endividamento externo, o planejamento no Brasil voltou-se prioritariamente para a estabilização monetária. Mas, em contraste ao período atual, o país foi marcado por uma forte presença estatal na elaboração de diversos planos cujo objetivo principal era o crescimento econômico, principalmente nas décadas de 50, 60 e 70.

Estes planos de desenvolvimento foram decisivos para 0 comportamento da economia brasileira ao longo de sua história. O processo de industrialização brasileiro, por exemplo, foi regido por uma estratégia econômica a partir da década de 30: a industrialização via substituição de importações, que provocou profundas mudanças sócio-econômicas no país. Após a Segunda Guerra, os mecanismos de planejamento econômico se sofisticaram, com a criação de organismos específicos para pesquisar a realidade brasileira e determinar técnicas de programação econômica. Podem ser citados alguns marcos deste período como o Plano de Metas, o Plano Trienal e o II Plano Nacional de Desenvolvimento (II PND).

Assim, por mais de trinta anos, a economia brasileira conviveu com estratégias desenvolvimentistas, amplamente divulgadas na literatura econômica. Contudo, a partir do final da década de 70, a política macroeconômica concentrou seus esforços nos objetivos de estabilidade 
econômica, principalmente no controle da inflação, das contas públicas e do setor externo. Desta forma, existem vários estudos que abordam o planejamento desenvolvimentista no Brasil até o final do II Plano Nacional de Desenvolvimento (1979), mas os estudos recentes da economia brasileira retratam apenas os planos de estabilização (Plano Cruzado, Plano Bresser, Plano Verão, Plano Collor I e II e Plano Real) como os delineadores da política macroeconômica do período atual.

Sabe-se porém, que o planejamento para o desenvolvimento se manteve presente durante as décadas de 80 e 90, embora não tivesse a ênfase dos planos desenvolvimentistas das décadas anteriores. A Constituição de 1988 estabelece, no artigo 21, que " compete à união elaborar e executar planos nacionais e regionais de ordenação do território e de desenvolvimento econômico e social". Consta ainda, no artigo 174, que o Estado, como agente normativo e regulador da atividade econômica exercerá, na forma de lei, as funções de fiscalização, incentivo e planejamento, sendo este determinante para o setor público e indicativo para o setor privado. A lei estabelece as diretrizes e bases do planejamento do desenvolvimento nacional equilibrado, o qual incorpora e compatibiliza os planos nacionais e regionais de desenvolvimento.

Assim, todos os governos após o lançamento da Constituição em 1988, tiveram, obrigatoriamente, que criar planos nacionais e regionais de desenvolvimento, estabelecendo o plano plurianual, as diretrizes orçamentárias e os orçamentos anuais. O governo atual, por exemplo, possui estratégias de desenvolvimento no chamado PPA-2000 (Plano Plurianual de Investimentos) ou Avança Brasil. Segundo o Ministério do Planejamento, este é um plano voltado para a consolidação da estabilidade econômica com crescimento sustentado, promoção do desenvolvimento com geração de empregos e oportunidades de renda. Assim como o PPA-2000, diversos planos governamentais de desenvolvimento foram elaborados no país após o II PND. Alguns destes planos não chegaram a ser 
implementados, outros por sua vez, tiveram um impacto reduzido sobre a economia brasileira.

Diante da escassez de estudos, na literatura econômica, que analisam a trajetória do planejamento desenvolvimentista da economia brasileira, durante as décadas de 80 e 90, faz-se necessário um estudo dos planos de desenvolvimento elaborados neste período, observando as peculiaridades de cada plano e as mudanças ocorridas nas prioridades de um plano a outro. Sendo assim, torna-se também necessária a análise dos fenômenos históricos e econômicos associados aos planos e a avaliação do impacto destes sobre os indicadores sócio-econômicos do país.

Desta forma, o presente trabalho busca contribuir para o estudo da economia brasileira recente, analisando, por meio de dados bibliográficos e documentais, os principais aspectos destes planos de desenvolvimento como, por exemplo, a sua abrangência, suas propostas, seu êxito quanto aos objetivos e seus resultados sobre a produção nacional, a taxa de investimento, o nível de emprego, a inflação, as dívidas externa e interna, os salários, a distribuição de renda, o índice de desenvolvimento humano (IDH) e o índice de pobreza.

\subsection{Objetivos}

\subsubsection{Objetivo geral}

Identificar e analisar os planos de desenvolvimento elaborados no país após o II PND e seus impactos sobre a economia brasileira. 


\subsubsection{Objetivos específicos}

Realizar um estudo da economia brasileira recente enfatizando o papel do planejamento para o desenvolvimento durante as décadas de 80 e 90;

Caracterizar cada plano de desenvolvimento segundo período, governo, ministérios, objetivos, tipos de gastos, fontes de financiamento, continuidade e causas do alcance ou fracasso dos objetivos;

Avaliar se os planos de desenvolvimento foram seguidos e, se foram, qual o grau de implementação;

Investigar os impactos dos planos de desenvolvimento elaborados no país sobre indicadores sócio-econômicos.

\subsection{Metodologia}

O presente trabalho busca retratar a trajetória da política de desenvolvimento no Brasil por meio de uma pesquisa bibliográfica e documental.

Para a análise dos planos de desenvolvimento do país até 1979 considera-se a literatura econômica e, para o período mais recente, são considerados os documentos da Presidência da República e do Ministério do Planejamento, Orçamento e Gestão na análise dos planos. Nestes documentos são divulgados os planos plurianuais que mostram as linhas gerais da política de desenvolvimento do país durante determinado período. Desta forma, torna-se possível identificar quais foram os planos de desenvolvimento elaborados e implementados no país após o II PND, seus 
principais objetivos, metas e diretrizes, a política de gastos públicos e a sua relação com a situação econômica e social do país.

Os dados coletados nestes documentos, são contrastados com os resultados apresentados pelos orçamentos anuais do governo federal, para a observação do grau de implementariedade dos planos. Estes resultados são ainda comparados com a evolução de indicadores econômicos e sociais de modo a observar uma possível relação entre as oscilações da política de desenvolvimento do país e os rumos do crescimento econômico nos últimos 20 anos.

Desta forma, a pesquisa consta de quatro etapas:

- 1ํ a pesquisa bibliográfica para a análise da evolução do planejamento no Brasil;

- 2ำ a pesquisa documental para a identificação, descrição e avaliação dos planos econômicos de desenvolvimento elaborados no país após o II PND;

- $\quad 3^{\circ}$ a comparação entre as propostas iniciais dos planos e os resultados destes, apresentados pelo governo federal, para se observar o grau de implementação dos planos;

- 4ํa a análise tabular e gráfica, para o estudo da evolução de indicadores econômicos e sociais, com a finalidade de contrastar estes indicadores às realizações dos planos considerados na pesquisa e observar a relação entre as mudanças na política de desenvolvimento e as transformações da economia brasileira nas últimas décadas. 


\section{REVISÃO DE LITERATURA}

\subsection{O planejamento econômico}

O planejamento econômico tem fundamentado a ação da política macroeconômica na maior parte das economias socialmente organizadas, principalmente a partir da década de 30, com o advento da Grande Depressão e o surgimento da teoria keynesiana. Antes desse período, a teoria econômica considerava os mercados competitivos, de forma que estes sempre alcançariam o ótimo de produção e o equilíbrio.

A antiga União Soviética foi a primeira a utilizar o planejamento de uma forma sistemática; já nos países capitalistas a idéia do planejamento surgiu diante da necessidade de se atingir certos objetivos econômicos e sociais, dadas as imperfeições do sistema de mercado. Se o mercado funcionasse perfeitamente, não haveria razão para a existência da política econômica e, por isso, esta é pouco considerada na teoria econômica clássica ou ortodoxa. Porém, com o fim da ideologia do laissez faire e diante da possibilidade do equilíbrio com desemprego, tornou-se clara a necessidade do planejamento econômico como forma de corrigir as distorções inerentes ao sistema capitalista.

Assim, a partir das propostas de política econômica conjunturais de Keynes, evidenciou-se a necessidade de cada governo desenvolver, por meio dos aparelhos do Estado, uma política econômica coerente para 
viabilizar o desenvolvimento econômico. Esta, contudo, não implicaria em exclusão da iniciativa privada.

A política econômica se divide entre a política conjuntural ou de curto prazo e a política de desenvolvimento. Esta última incorpora o plano de desenvolvimento, que por sua vez, subdivide-se em programas de desenvolvimento. Assim, torna-se necessário o conhecimento de cada uma destas etapas da política econômica que geram o planejamento do desenvolvimento, bem como suas justificativas e seus objetivos. Neste tópico da revisão literária procura-se entender estes conceitos relativos ao planejamento, observando a opinião de diversos autores sobre o tema.

Segundo Tinbergen (1969), a política de desenvolvimento deve ter como objetivos principais criar as condições gerais favoráveis ao desenvolvimento, efetuar investimentos, principalmente em infra-estrutura e tomar as providências necessárias para facilitar e estimular o investimento e a atividade privada. Estes objetivos geram a programação ou planejamento do desenvolvimento, a cargo do Estado, que compreende determinados projetos públicos e privados. Neste processo, os responsáveis pelo planejamento devem ter, como referencial básico, o fato de que a utilização dos recursos escassos deverá ser feita da maneira mais racional e eficiente possível.

Para Tinbergen (1969), nos primeiros estágios do desenvolvimento, deve-se dar mais ênfase aos investimentos básicos destinados a eliminar os pontos de estrangulamento da economia. Nos posteriores, com a economia mais desenvolvida, deve-se dar maior importância aos estímulos a serem prestados à iniciativa privada. Já Waterson (1970), considera que o crescimento econômico acelerado e a mudança estrutural são os dois principais objetivos, explícitos ou implícitos, do planejamento do desenvolvimento.

Para Holanda (1983), a necessidade do planejamento está relacionada às crescentes expectativas da sociedade por melhores padrões de vida e à conscientização de que o sistema de preços é incapaz de 
produzir, principalmente em países subdesenvolvidos, as transformações estruturais necessárias para que a economia ingresse em um estágio superior de crescimento sustentado. São apontadas as seguintes deficiências do sistema de preços: imperfeições de mercado, sob a forma de monopólios e oligopólios; divergências entre custos sociais e custos privados; a crescente complexidade dos processos tecnológicos; problemas estruturais que geram desigualdades na distribuição de renda, entre pessoas e regiões, e são responsáveis por uma insuficiente taxa de formação de poupança e a debilidade do setor empresarial privado. Além destas deficiências, Holanda (1983) argumenta que, para países subdesenvolvidos, o planejamento econômico também é justificado pela existência de condições históricas e institucionais bastante diferentes daquelas que propiciaram o desenvolvimento de países da Europa Ocidental e da América do Norte.

Assim como Holanda (1983), Jaguaribe (1961) considera que a fundamentação da programação baseia-se na convicção de que o desenvolvimento espontâneo é um caso estatisticamente raro ou historicamente irrepetível.

Sobre a política econômica, Bresser Pereira (1998, p.147) fez a seguinte consideração:

"há dois tipos de política econômica: a política estrutural ou de médio prazo, na qual se enquadra o planejamento econômico e a política de rendas, e a política de curto prazo ou conjuntural. A primeira preocupa-se com o desenvolvimento econômico, a taxa de acumulação, os desequilíbrios regionais e a distribuição de renda. A segunda preocupa-se com fenômenos mais imediatos de equilíbrio macroeconômico (interações entre a demanda e a oferta agregadas) e de equilíbrio financeiro (inflação, taxa de juros e equilíbrio externo)".

Bresser Pereira (1998) também considera que, em uma economia capitalista, a política econômica é o processo através do qual o Estado 
intervém no mercado, corrigindo-o e orientado-o para determinados objetivos. O planejamento econômico é, neste sentido, o meio segundo o qual o governo pode alcançar estes objetivos.

Assim, o planejamento econômico pode ser entendido como um modelo teórico para a ação, como uma forma de organizar racionalmente o sistema econômico a partir de certas hipóteses sobre a realidade. Neste, há sempre uma busca por se atingir determinados objetivos como, por exemplo, evitar as crises cíclicas e o desemprego, estimular o desenvolvimento, mobilizar recursos em períodos de guerra, etc.

Considera-se que o planejamento não é apenas um trabalho periódico, ou um plano para um determinado número de anos, mas um processo contínuo, que requer adaptações e correções freqüentes para considerar todas as modificações com relação às condições iniciais, como também para ir incorporando as experiências que o próprio processo de planejamento vai oferecendo.

Nas economias capitalistas o planejamento global procura dar uma visão ampla do desenvolvimento da economia, fixando objetivos a atingir e procurando assegurar a consistência entre a oferta e a demanda de bens em todos os setores (Lafer, 1970). Desta forma, o planejamento passa por três fases: a decisão de planejar e a formulação do plano em si (com a definição dos objetivos), que são decisões políticas, o detalhamento e a implementação do plano, que podem ser examinadas do ponto de vista técnico.

Segundo Lafer (1970, p.23),

"a decisão de planejar é essencialmente uma decisão política, pois é uma tentativa de alocar explicitamente recursos e, implicitamente, valores, através do processo de planejamento e não através dos demais e tradicionais mecanismos de sistema político. A implementação do plano é, também, essencialmente, um fenômeno político pois é uma forma de se aferir o quanto da tentativa de alocar 
recursos e valores se efetivou ou, em outras palavras, qual é a relação num dado sistema entre política e administração. O plano em si é, de todas as fases mencionadas do processo de planejamento, a que melhor pode ser examinada de um ponto de vista estritamente técnico, pois, mormente se existir um documento escrito, o plano pode ser analisado à luz de critérios econômicos, através dos quais se testa a sua consistência interna e a compatibilidade de seus objetivos."

Segundo Jaguaribe (1961), a programação econômica é a técnica de provocar a ocorrência de uma intervenção deliberada no processo econômico, fundada no conhecimento racional deste e orientada de conformidade com um plano. Este plano passaria por duas etapas: preparação e execução. A preparação constitui a análise ou diagnóstico da situação, a escolha dos objetivos e a determinação dos meios para atingir tais objetivos. A execução incorpora a implementação dos novos mecanismos legais e administrativos e a operação desses mecanismos. A eficácia do plano, por sua vez, dependeria de sua validade como plano e de sua vigência, como norma, ou seja, da efetiva observância do plano pelos agentes que deveriam cumpri-lo.

Para Robinson (1974), os planos nacionais abrangem um campo amplo e objetivam o cálculo de todas as atividades importantes da economia. E, além de considerar os problemas da produção e o uso de recursos, examinam a posição comercial do país em relação ao resto do mundo, o equilíbrio entre seus planos de investimento e a oferta de novos fundos sob a forma de poupança, etc.

Os planos nacionais interessam-se pelos futuros lançamentos em todas as contas da matriz de contabilidade social e podem ser considerados como um processo de pesquisa sobre o conjunto de possibilidades abertas à economia, e de seleção daquela possibilidade que parece ser a melhor.

Estudos realizados pela Comissão Econômica para a América Latina (CEPAL, 1961) destacavam que a finalidade de um programa de 
desenvolvimento é a de proporcionar uma base analítica adequada para diferentes tipos de política. Estas bases, sobre as quais se assenta a intervenção governamental, no processo de crescimento econômico, são as seguintes:

- deficiências do mecanismo de mercado para o alcance de um aproveitamento ótimo de recursos;

- a variedade dos instrumentos de política econômica utilizados pelos governos e seu fundamento lógico;

- as técnicas analíticas de que se dispõe para formular programas de desenvolvimento.

Estes estudos afirmavam ainda que a determinação de uma política deve fundamentar-se em critérios objetivos e que as hipóteses da Concorrência Perfeita são limitadas nos países pouco desenvolvidos. Assim, a política de desenvolvimento deve tentar alcançar vários objetivos a longo prazo, entre os quais o mais importante é o crescimento do investimento total. Estes objetivos da política econômica são normalmente múltiplos e podem ser quantitativos ou qualitativos, sendo expressos em um programa de desenvolvimento.

O programa de desenvolvimento é uma análise econômica que fornece as bases para formular e executar a política correspondente. Desta forma, não há uma distinção nítida entre a formulação de um programa e de uma política. Segundo Chenery (1961), a formulação de um programa deve atender às seguintes condições: coerência, eficiência e viabilidade. Deve também passar por três fases: o diagnóstico, a programação e a execução.

No caso do desenvolvimento de um país ou região, o diagnóstico deve determinar quais são os principais fatores que influenciam a magnitude do crescimento e que criam obstáculos à estabilidade econômica. Isto implica em medir se a taxa de crescimento que o país está experimentando é compatível com a estabilidade econômica, assim como é necessário conhecer as características estruturais desta economia. A partir deste conhecimento é realizada a programação cujo programa deve possuir a 
"terapêutica para remediar os males descobertos pelo diagnóstico". Em outras palavras, deverá fixar metas expressas em termos quantitativos e determinar os meios necessários para alcançá-los. Essas metas podem referir-se a produção de bens e serviços, à utilização destes bens e à distribuição destes em bens de consumo, investimento ou exportáveis e entre os membros da sociedade.

Segundo Ahumada (1960), uma das condições para a eficácia do planejamento consiste em permitir a comprovação da compatibilidade entre os fins e metas e assegurar que estas são realistas, tanto do ponto de vista técnico, como do ponto de vista político, comparando recursos existentes com as propostas.

Quantificadas as metas e fixados os meios, comprovados o seu realismo, começa a etapa de execução do plano que consiste na edição, aprovação e execução das medidas de política econômica e na construção das obras que correspondem ao setor público. Assim, é necessário ao governo que existam instrumentos administrativos que permitam revisar continuamente o plano para adaptá-lo às condições estabelecidas e comprovar se sua execução está seguindo o itinerário proposto (Ahumada, 1960).

Estudos da CEPAL (1961) consideravam ainda que o rigor científico e sua neutralidade seriam fatores importantes para conseguir de forma progressiva o nível desejado de racionalidade no planejamento, sem a qual seria difícil alcançar a eficácia sobre a decisão de influenciar consciente e deliberadamente as forças de mercado da economia. Neste sentido, a adoção do planejamento significa reconhecer que o livre jogo das forças de mercado não resolvem eficazmente os problemas do desenvolvimento.

No Brasil, o planejamento econômico está presente desde o início do processo de industrialização até os dias de hoje, ora incorporando como objetivo principal o crescimento econômico ora focalizando a estabilidade monetária. Segundo Ianni (1971), o primeiro grande objetivo do planejamento econômico no Brasil é aumentar o grau de eficácia e 
racionalidade da política econômica, em bases qualitativas e quantitativas. $\mathrm{O}$ segundo grande objetivo é dar às forças representativas do país a consciência dos objetivos nacionais a serem alcançados.

Entretanto, o planejamento econômico, quando foi proposto como solução para os problemas do país gerou opiniões controversas. Encontrou resistências, uma vez que este chegou a ser considerado como uma ameaça de socialismo, pelos antigos defensores do laissez faire que o utilizavam para contestar as tentativas de planejamento. Já os economistas estruturalistas, empenhados na defesa da industrialização, viam o planejamento como um instrumento essencial para o desenvolvimento econômico e para dar coerência à ação do Estado.

Para Bresser Pereira (1998), na realidade, o planejamento revelouse um instrumento útil, embora limitado para promover o desenvolvimento econômico. Foi um fator de aceleração das taxas de crescimento da economia e de industrialização, embora não conseguisse superar o caráter cíclico da economia.

Segundo Robock (1977), como uma das fontes de crescimento, o planejamento no Brasil ofereceu uma contribuição permanente por meio da melhoria e do aclaramento do processo decisório, tanto no plano privado como no governamental. Para ele, o planejamento manteve uma posição de influência e de eficácia política em quase todo o período subseqüente à Segunda Guerra.

O mérito da evolução brasileira do planejamento econômico foi o reconhecimento real, embora não explícito, de que o país não estava preparado em termos de recursos técnicos, pessoal e institucionais para "correr antes de saber andar" (Robock, 1977). 


\subsubsection{A controvérsia do planejamento econômico}

Um clássico exemplo da controvérsia sobre o planejamento econômico é o debate que surgiu no país entre Roberto Simonsen, defensor do planejamento, e Eugênio Gudin, seguidor da ideologia liberal, a partir do final do Estado Novo.

Em um parecer apresentado ao Conselho Nacional de Política Industrial e Comercial, Simonsen colocava sua opinião a respeito da planificação no Brasil. Para ele, impunha-se a planificação da economia brasileira como forma de proporcionar os meios adequados para satisfazer as necessidades essenciais da população e prover o país de uma estruturação econômica e social, forte e estável, fornecendo à nação os recursos indispensáveis à sua segurança e à sua colocação em lugar condigno, na esfera internacional. Para isto contaria com a ciência e a técnica, que forneceriam seguros elementos para o delineamento dessa planificação (IPEA, 1977).

Simonsen considerava que um programa visando a elevação da renda a um nível suficiente para atender aos imperativos nacionais, teria que ser constituído pela industrialização, unida ao aperfeiçoamento da atividade agrícola. E esta industrialização dependeria do aperfeiçoamento do sistema de transportes, de distribuição e comércio. Desta forma, a planificação deveria abranger por igual, os problemas industriais, agrícolas e comerciais, assim como os sociais, econômicos e de ordem geral (IPEA, 1977).

O autor concluiu o parecer mostrando que, entre outros aspectos, era aconselhável a planificação de uma nova estruturação econômica, de forma que fossem criadas, dentro de determinado período, a produtividade a as riquezas necessárias para o alcance de uma suficiente renda nacional.

A reação contra as propostas de Simonsen, foi realizada por Gudin em um novo relatório. Neste, Gudin afirmava que a planificação exigia um 
detalhamento da vida econômica do país e uma ininterrupta vigilância do Estado sobre as atividades industriais, ao contrário da doutrina do laissez faire, cujo impacto rapidamente ruiu o sistema mercantilista, baseando-se no princípio de que a riqueza da nação é a integral riqueza de seus cidadãos. Portanto, o meio mais rápido e seguro de enriquecer a nação seria o de deixar aos indivíduos a plena liberdade de ação econômica. Para Gudin, a doutrina do laissez faire era a negação do plano (IPEA, 1977).

Segundo Gudin, o ideal é que o mercado seja livre, que haja mobilidade de fatores de produção e que a produção seja regulada pelo mecanismo de preços, traduzindo a demanda efetiva de mercadorias e serviços.

Gudin considerava que a "mística da planificação" era uma derivação da experiência do "New Deal" americano, das ditaduras italiana e alemã que levaram o mundo à catástrofe, e dos planos qüinqüenais da Rússia, que nenhuma aplicação podiam ter a outros países. Para este autor, a "mística do plano" poderia constituir um precioso instrumento para a vitória de doutrinas políticas ou de interesses econômicos. Para os socialistascomunistas o plano seria uma invasão pelo Estado no campo da economia e da iniciativa privada. A burocracia passaria a ter nas mãos uma soma considerável de poderes na direção da economia e, para os interesses reacionários, o plano seria um instrumento excelente de eliminação da concorrência e de consolidação, sob a égide governamental, das situações adquiridas (IPEA, 1977).

Simonsen reage às críticas de Gudin, lançando um novo parecer no qual defende que o planejamento representa uma coordenação de esforços para um determinado fim. Para ele, se a renda nacional era baixa, se os níveis de vida eram miseráveis, se existiam recursos naturais e espaços de terra não aproveitados, se a técnica e a ciência ofereciam os instrumentos essenciais para, dentro de um planejamento racional, corrigir esse estado de atraso, por que não adotá-lo? 
Segundo Simonsen, não havia uma mística do plano, mas um poderoso instrumento de ação econômica e social, capaz de agir, eficientemente, em relação aos gravíssimos problemas do país. Assim, considerava o planejamento como um esforço constante para dirigir a energia humana, objetivando uma finalidade racionalmente predeterminada. "É uma técnica, um processo, uma metodologia e não um sistema de governo". Finalizando, Simonsen resume bem a justificativa para o planejamento econômico:

"Acreditava-se no século XIX que a riqueza da comunidade era igual à soma total do bem estar material dos indivíduos e que assim, cada um, desejando melhorar sua própria condição econômica, contribuía, automaticamente, para a riqueza da comunidade em geral. Desnecessário era portanto, o controle governamental no regime dos negócios. Mas a devastação das riquezas naturais, a ausência de defesa em relação aos múltiplos fenômenos meteorológicos, as sucessivas crises econômicas, a existência da miséria em meio à abundância, a crescente concentração de riquezas em mãos de um pequeno número, a exploração do homem pelo homem, toda uma série de imensos problemas criados pelas grandes aglomerações urbanas, a profunda diferenciação na evolução entre as nações ricas e as nações pobres, a impossibilidade do sistema de preços refletir, num dado momento, as condições prováveis dos mercados futuros, tornaram evidente a insuficiência do primitivo automatismo social e econômico, admitido pelos economistas clássicos" (IPEA, 1977, p.181). 


\subsubsection{Os problemas de programação do setor público}

Vistos os argumentos em prol da necessidade de programação do setor governamental, diversos problemas se apresentam na atividade de planejar a economia. De um modo geral, estes problemas relacionam-se à imprecisão do planejamento quando ocorrem múltiplos objetivos não relacionados às ações do projeto, quando a responsabilidade pela gerência do projeto não é clara e referem-se também à definição dos critérios próprios de implementação e avaliação dos planos. Segundo Pinto (1960), outro problema enfrentado pelo planejamento é o financiamento do desenvolvimento. Para ele este se constitui no problema principal da estratégia de programação do crescimento de um país.

Sabe-se que o planejamento visa permitir a melhor coordenação entre as várias medidas de política econômica, no que se refere aos instrumentos utilizados e à compatibilidade de metas. Assim, o planejamento econômico tem como um de seus papéis direcionar a acumulação para determinados setores considerados prioritários, após realizar o diagnóstico e verificar qual setor precisa ser especialmente desenvolvido.

Segundo Bresser Pereira (1998), para orientar os investimentos, o Estado dispõe de dois instrumentos:

- direcionar para determinado setor produtivo, os investimentos de suas próprias empresas ou das empresas que cria para isso;

- direcionar a acumulação para determinados setores tornando as suas perspectivas de lucro extraordinariamente atrativas por meio de subsídios fiscais e creditícios.

Neste sentido, esse tipo de planejamento pode trazer enormes distorções para a economia como a concentração de renda, o desequilíbrio orçamentário e a inflação. 
"O planejamento, como a inflação, transformou-se realmente em um mecanismo de transferência de rendas dos trabalhadores para os capitalistas, dos setores menos prioritários para os mais prioritários, sendo que a definição do que seja um setor prioritário nem sempre obedece a critérios econômicos objetivos, mas a critérios políticos... além disso, para se beneficiar dos subsídios, a empresa precisa ter uma certa dimensão, certa capacidade de negociação com as entidades oficiais que os concedem" (Bresser Pereira, 1998, p.150).

Além destes graves problemas enfrentados pelo planejamento econômico, Silva (1974) mostra que definidos os objetivos e as metas do planejamento econômico nacional, bem como o grau esperado de participação do setor público nos diferentes setores, face às metas estabelecidas, os problemas de programação envolvem ainda a análise das alternativas e a escolha da forma mais eficiente, tanto no que se refere à arrecadação dos recursos necessários, quanto à política de despesas.

Assim, os principais problemas existentes na programação das despesas seriam:

- de natureza técnica: como as dificuldades encontradas no estabelecimento de métodos operacionais para a integração das decisões orçamentárias com o planejamento nacional, mediante quantificação de resultados e custos em cada programa, e das repercussões desses resultados do ponto de vista da concretização dos objetivos nacionais;

- e de natureza político-institucional, que se referem ao fato de as decisões orçamentárias não incluírem apenas problemas de racionalidade econômica na aplicação dos recursos, mas fatores políticos e institucionais que interferem nessas decisões. 


\subsection{O Sistema de Planejamento Integrado}

A palavra planejamento no Brasil tem sido usada de maneira pouco precisa para significar uma simples declaração de princípios, um programa de desenvolvimento ou um plano de desenvolvimento. A declaração de princípios é apenas uma proposta vaga de metas e estratégias de desenvolvimento econômico. Já um programa aborda prioridades setoriais ou regionais e reformula incentivos ou desestímulos relativos às prioridades selecionadas. Um plano de desenvolvimento elabora esses elementos, especificando um cronograma para a efetivação, atribuindo responsabilidade a um agente determinado e alocando recursos financeiros e materiais.

Até a promulgação da nova constituição, competia ao Poder Executivo elaborar um Plano Nacional de Desenvolvimento (PND), um orçamento plurianual de investimentos e três orçamentos anuais - o Orçamento da União, o Orçamento Monetário e o Orçamento das Empresas Estatais. Atualmente, o governo utiliza técnicas de planejamento e programação de ações que são condensadas no chamado Sistema de Planejamento Integrado. Este sistema busca analisar a situação atual para identificar as ações ou alterações a serem desenvolvidas para atingir a situação desejada.

A adoção desse sistema deveu-se a estudos técnicos e científicos, levados a efeito pela Organização das Nações Unidas (ONU), com o objetivo de determinar as ações a serem realizadas pelo poder público, escolhendo as alternativas prioritárias e compatibilizando-as com os meios disponíveis para colocá-las em execução.

O Sistema de Planejamento Integrado busca, por meio da escolha de alternativas prioritárias, o melhor emprego dos meios disponíveis para minimizar os problemas econômicos e sociais existentes. No Brasil, este sistema também é conhecido como Processo de Planejamento-Orçamento, 
consubstanciando-se nos seguintes instrumentos, atendendo ao mandato constitucional (Art.165), da Constituição:

- Plano Plurianual (PPA);

- Lei de Diretrizes Orçamentárias (LDO);

- Lei de Orçamentos Anuais (LOA).

O plano plurianual é um plano de médio prazo, através do qual procura-se ordenar as ações do governo que levem ao atingimento dos objetivos e metas fixados para um período de 4 anos, ao nível do governo federal, e de 4 anos ao nível dos governos estaduais e municipais.

Segundo o Art. 165 da Constituição, a lei que instituir o plano plurianual estabelecerá, de forma regionalizada, as diretrizes, objetivos e metas da administração pública para as despesas de capital e outras decorrentes e para as relativas aos programas de duração continuada.

Já a Lei de Diretrizes Orçamentárias tem a finalidade de nortear a elaboração dos orçamentos anuais (orçamento fiscal, o orçamento de investimento das empresas estatais e o orçamento da seguridade social), de forma a adequá-los às diretrizes, objetivos e metas da administração pública, estabelecidas no plano plurianual. A Lei de Diretrizes Orçamentárias deve compreender as metas e prioridades da administração pública, incluindo as despesas de capital para o exercício financeiro subsequente, orientar a elaboração da lei orçamentária anual, dispor sobre as alterações na legislação tributária e estabelecer a política de aplicação das agências financeiras oficiais de fomento.

O Orçamento Anual é elaborado para viabilizar a concretização das situações planejadas no plano plurianual e, obviamente, transformá-las em realidade, obedecida a Lei de Diretrizes Orçamentárias. Assim, no Orçamento Anual são programadas as ações a serem executadas, visando alcançar os objetivos determinados.

Segundo Giacomoni (1996) se a fase é expansionista, cresce a importância da função de planejamento do orçamento, já na fase contracionista, fica reforçada a sua função de controle. Para o autor, o 
Orçamento Anual é o instrumento de operacionalização de curto prazo da programação constante dos planos setoriais e regionais de médio-prazo, os quais, por sua vez, cumprem o marco fixado pelos planos globais de longo prazo onde estão definidos os grandes objetivos e metas, os projetos estratégicos e as políticas básicas.

Assim, a principal matéria-prima utilizada para a elaboração da proposta do orçamento é buscada pelos elementos integrantes do Sistema de Planejamento.

A Lei Orçamentária Anual compreende:

- o orçamento fiscal;

- o orçamento dos investimentos das estatais;

- o orçamento da seguridade social.

Segundo Kohama (1998), o conceito atual de orçamento é o de que este é o processo pelo qual se elabora, expressa e avalia o nível de cumprimento da quase totalidade do programa de governo, para cada período orçamentário. É um instrumento de governo, de administração e de efetivação e execução dos planos gerais de desenvolvimento sócioeconômico.

Para Silva (1995), o orçamento-programa contribui para o planejamento governamental pois é capaz de expressar melhor as responsabilidades do governo para com a sociedade, visto que o orçamento deve indicar com clareza os objetivos perseguidos pela nação.

Assim, considera-se o planejamento como um processo racional para definir objetivos e determinar os meios para alcançá-los, obedecendo às seguintes características:

- diagnóstico da situação existente;

- identificação das necessidades de bens e serviços;

- definição clara dos objetivos para a ação;

- discriminação e quantificação de metas e seus custos;

- avaliação dos resultados obtidos;

- trabalho integrado. 
O Planejamento deve atender aos seguintes princípios: racionalidade, previsão, universalidade, continuidade e aderência. Para isto, o processo de planejamento é desenvolvido nos seguintes níveis que integram e sincronizam os planos:

Diretriz: conjunto de critérios de ação e decisão que deve disciplinar e orientar os diversos aspectos envolvidos no processo de planejamento. Trata-se de um nível mais abstrato em que ocorre a formulação geral do objetivo.

Objetivo: indica os resultados que a administração pública pretende alcançar com a realização das ações governamentais.

Metas: é a especificação e quantificação física dos objetivos estabelecidos.

Programa: corresponde às ações que resultam em serviços prestados à comunidade passíveis de quantificação.

Para Giacomoni (1996), o planejamento, a programação e a orçamentação constituem os processos por meio dos quais os objetivos e os recursos, e as suas inter-relações, são levadas em conta visando à obtenção de um programa de ação, coerente e compreensivo para o governo como um todo.

Assim, este modelo de planejamento busca integrar os diagnósticos e prognósticos, os objetivos, a análise de cursos alternativos, os programas e os projetos com suas metas, os recursos a serem empregados, a indicação de custos, os esquemas de avaliação e controle.

No novo modelo de planejamento, instituído pela Constituição de 1988, as LDO e os Orçamentos Anuais têm que ser compatíveis com o que dispõe o PPA, bem como com todos os planos e programas nacionais, regionais e setoriais previstos na Constituição. Segundo Garcia (2000), nenhum investimento cuja execução ultrapassar um exercício financeiro poderá ser iniciado sem prévia inclusão no PPA ou sem lei que autorize tal inclusão, sob pena de crime de responsabilidade. 
Assim, nesse modelo, nota-se a intenção de se criar um instrumento que explicite os objetivos do governo, dê coerência às ações ao longo do tempo e organize as intervenções parlamentares nos orçamentos, assim como há a preocupação em criarem-se condições para o exercício regular da avaliação e do controle das ações e, em particular, das despesas públicas.

O artigo 74, I e II da Constituição Federal determina que os Poderes Legislativo, Executivo e Judiciário manterão, de forma integrada, sistema de controle interno com a finalidade de avaliar o cumprimento das metas previstas no PPA e a execução dos programas de governo e dos orçamentos da União. Exige também, a comprovação da legalidade e a avaliação dos resultados quanto à eficácia e à eficiência da gestão orçamentária, financeira e patrimonial dos órgãos e entidades da administração federal.

Alguns problemas concernentes ao modelo são apontados como, por exemplo, o fato de que as crises econômicas e a conseqüente escassez de recursos para novos empreendimentos, a falta de recursos técnicos e as dificuldades políticas podem dificultar ou até mesmo impedir a implementação dos planos.

Além disto, os críticos ao modelo apontam também para a descrença quanto às possibilidades do modelo ajudar, especialmente os países subdesenvolvidos a minorarem seus problemas. Segundo Waterson (1970), embora os planos de desenvolvimento tenham proliferado e as técnicas utilizadas sejam melhores, a taxa anual média de crescimento do produto interno real nos países menos desenvolvidos não demonstra qualquer melhoria sensível na América Latina desde os anos 50, chegando mesmo a declinar na Ásia Meridional e Sudeste.

Para Waterson (1970), a instabilidade política e a incerteza econômica seriam incompatíveis com o modelo de planejamento baseado em planos de médio e longo prazo. Além disso, deficiências técnicas, falta de dados e inexistência de sistemas administrativos adequados tornariam os modelos inviáveis. Para ele, estes modelos seriam viáveis apenas no pressuposto de estabilidade política e econômica. Como essa não é a 
realidade dos países em desenvolvimento, estes deveriam abandonar os planos globais de longo e médio prazo e adotar um sistema que dê ênfase ao plano anual, associado a programas setoriais plurianuais.

Outra crítica de Waterson (1970) diz respeito aos resultados do planejamento. Segundo ele, estes não são satisfatórios o que se deve, em parte, à deficiência de método e, em grande parte, ao ambiente desfavorável em que com freqüência o planejamento convencional opera. Mas a razão mais importante apontada é a de que o planejamento convencional não satisfaz às necessidades sociais. Segundo o autor, é nesse último sentido que existem as maiores razões para se afirmar que o planejamento convencional tem fracassado, pois é aí que costuma ser maior a distância entre as aspirações e os resultados obtidos.

\subsection{A experiência brasileira de planejamento}

Até os anos 30, ocorreram poucas tentativas de planejamento no Brasil, principalmente quanto ao desenvolvimento industrial, embora tenha sido empregado algum planejamento nas políticas de defesa do café. Mas, neste período, o planejamento foi marcado pela ocasionalidade e falta de continuidade. A política de livre comércio do século XIX representou um programa consciente para manter a estrutura predominante na época. No final do século XIX e início do século XX, houve tentativas de indivíduos, pertencentes ao governo ou não, de realizar avaliações sistemáticas da

economia brasileira para a recomendação de políticas para o Balanço de Pagamentos e outros problemas brasileiros. Um exemplo deste fato é o Programa de Estabilização de Joaquim Murtinho (1888-1902) (Baer, 1996).

Já a partir da década de 40, várias tentativas de coordenar, controlar e planejar a economia brasileira foram observadas. No entanto, 
são raros os exemplos de atividades governamentais planejadas no país, antes de 1939. Contribuíam para isto as restrições ideológicas impostas pelas correntes liberais e o desconhecimento de técnicas avançadas de política e programação.

Desta forma, observa-se que somente a partir das décadas de 30 e 40, as avaliações da economia brasileira tornaram-se mais freqüentes. O primeiro relatório a surgir nos anos 30 foi o Niemeyer Report de 1931, de Sir Otto Niemeyer, convidado pelo governo brasileiro para estudar meios que fizessem com que país superasse a crise econômica gerada pela depressão. Neste documento, Niemeyer declarava a principal fraqueza da economia brasileira: a exportação de apenas um ou dois bens agrícolas, o que explicava porque a crise mundial atingiu o país mais fortemente do que as nações industrializadas.

Segundo Baer (1996), as críticas à excessiva confiança que o Brasil depositava no café eram consideradas quase um "sacrilégio" na época e, assim, o relatório acabou despertando pouco interesse. Niemeyer defendeu a diversificação da estrutura econômica brasileira, referindo-se à diversificação agrícola, que elevaria a renda do setor e, combinada com as reservas cambiais, acabaria por gerar os recursos necessários para o investimento na indústria.

O Niemeyer Report também criticava as finanças públicas no Brasil e os métodos utilizados para restruturá-las. Apesar de pouco influenciar a política econômica da época, o relatório representou o primeiro empenho por parte das autoridades do país em ter a economia examinada como um todo, com a possibilidade de mudar os rumos de seu desenvolvimento.

No início dos anos 40, encontram-se planos mais elaborados, bem como a criação de organismos específicos para formular, executar e controlar os planos do governo. Para isto, seria necessário um maior conhecimento da estrutura da economia brasileira, de forma a recomendar medidas para transformá-la. Então, neste período, o país solicitou aos Estados Unidos o envio de missões para levantamentos preliminares dos 
recursos e das possibilidades do país, como a Missão Cooke Para a Mobilização Econômica e a Missão Abbink que posteriormente deram origem ao Plano Salte.

A Missão Cooke visitou o país entre 1942 e 1943 e foi formada por um grupo de técnicos americanos patrocinados pelos governos brasileiro e americano cujo propósito era o de determinar a maneira pela qual o Brasil poderia colaborar com os esforços de guerra.

A Missão Cooke representou o primeiro trabalho de pesquisa analítica e sistemática realizado em relação à economia brasileira visando a formulação de um programa de ação. Além disto, pela primeira vez o país foi analisado sob o ponto de vista regional, mostrando que características regionais diferentes justificavam programas de desenvolvimento diversos.

O trabalho concluiu que era preciso um esforço para desenvolver o sul, visto que esta era a região que possuía as melhores condições para o rápido crescimento econômico. Supunha-se que a partir de um núcleo de desenvolvimento, este se espalharia para as outras regiões. A Missão indicou também os fatores que constituiriam obstáculos ao desenvolvimento econômico: o sistema de transportes inadequado; o sistema de distribuição de combustível retrógrado; a falta de recursos para investimentos industriais; as restrições ao capital estrangeiro e à imigração; instalações inadequadas para o treinamento técnico e a capacidade subdesenvolvida para a geração de energia.

Desta forma, a Missão Cooke recomendou: a expansão da indústria siderúrgica, que seria a base para o desenvolvimento de indústrias de bens de capital e a expansão das instalações para a produção têxtil, tanto para consumo interno quanto para o mercado exportador. Assim, a industrialização deveria ser deixada a cargo do setor privado e o governo deveria se concentrar no planejamento industrial em geral, desenvolvendo recursos de crédito industrial e proporcionando instrução técnica. 
O principal efeito da Missão Cooke foi o de esclarecer alguns problemas do desenvolvimento do país, exercendo pouca influência direta sobre políticas econômicas imediatas.

Historicamente, consideram-se ainda, como o início do planejamento no Brasil, o Plano Especial de Obras Públicas e Aparelhamento da Defesa Nacional de 1939 e o Plano de Obras e Equipamentos de 1943, que visavam principalmente fixar metas para a área estatal. O primeiro não era propriamente um plano, mas um projeto com uma lista de investimentos. Sua contribuição ao conceito de planejamento reside na duração de cinco anos e na sua característica de orçamento especial. O Plano de Obras e Equipamentos era também qüinqüenal e dava ênfase à programação de obras públicas de infra-estrutura e à criação de indústrias básicas. Entretanto sua duração efetiva foi de apenas dois anos, sendo extinto em 1946 como decorrência do fim do governo de Getúlio Vargas.

Todo este período posterior aos anos 20 é também marcado, em termos de programação econômica, pelo modelo de desenvolvimento industrial adotado no Brasil e em outros países da América Latina. Este modelo ficou conhecido como Industrialização por Substituição de Importações e prevaleceu desde a década de 30 até completar-se no final da década de 70, direcionando a ação estatal e norteando os planos de desenvolvimento.

Sabe-se que o modelo primário-exportador característico do país até a década de 30 sofreu modificações decorrentes das crises do comércio exterior de 1914 a 1945. Assim, a partir da década de 30, a economia brasileira procurou voltar-se para "dentro" com uma mudança nas variáveis dinâmicas da economia: do setor agrário exportador (variável exógena) para o investimento destinado ao desenvolvimento da indústria (variável endógena).

A partir daí, teve início o processo de substituição de importações que pode ser entendido como um processo de desenvolvimento "parcial" e "fechado" que, respondendo às restrições do comércio exterior, procurou 
repetir aceleradamente, em condições históricas distintas, a experiência de industrialização dos países desenvolvidos.

Segundo Tavares (1972), a substituição de importações é um processo de desenvolvimento que tem lugar e se orienta sob o impulso de restrições externas e se manifesta, primordialmente, através de uma ampliação e diversificação da capacidade produtiva industrial. Este processo possui limitações internas, que impedem a continuidade do processo de industrialização, tais como a dimensão e estrutura do mercado nacional, a natureza da evolução tecnológica e a desproporção dos recursos produtivos.

Várias críticas foram feitas à este processo de industrialização da América Latina. Uma delas refere-se ao fato de que a industrialização, segundo Tavares (1972), conduziu, em geral, a uma insuficiente absorção da força de trabalho e à uma estrutura de mercado escassamente competitiva com custos de produção elevados, mantendo uma distribuição de renda extremamente desigual.

Outras críticas referem-se à falta de planejamento econômico, que utilizasse, de uma maneira coordenada, todo o instrumental de política econômica à disposição do governo, para evitar as tensões inflacionárias e o aumento dos desequilíbrios setoriais e regionais.

"Do ponto de vista estrito da substituição de importações, o planejamento vai-se tornando cada vez mais necessário à medida em que o processo avança" (Tavares, 1972, p.68). Desta forma, o planejamento dos investimentos públicos e privados mostrou-se, a partir desta época, indispensável para evitar descontinuidades no aparelho produtivo do sistema e consideráveis desperdícios de recursos.

Assim, a partir da estratégia de substituição de importações, a política econômica brasileira manteve duas linhas mestras de ação. A primeira refere-se à política de comércio exterior, principalmente a cambial que, embora variando de mecanismos, manteve uma discriminação efetiva entre as importações, dando tratamento preferencial aos bens de capital e certos insumos essenciais. A segunda foi a política de investimento que 
avançou para a eliminação dos pontos de estrangulamento nos setores de infra-estrutura e o financiamento e orientação de outros investimentos através do Banco Nacional de Desenvolvimento Econômico (BNDE).

Estas duas linhas de ação estiveram presentes na maior parte dos planos de desenvolvimento elaborados pelos sucessivos governos nacionais, principalmente a partir do Plano de Metas. Entretanto, o planejamento, propriamente dito, tem como marco inicial o Plano Salte.

\subsubsection{O Plano Salte (1950-1951)}

Enquanto no mundo capitalista desenvolvido, especialmente nos países europeus envolvidos na reconstrução do pós-guerra, o planejamento estatal estava sendo intensamente utilizado, a única tentativa de intervenção planejada do Estado no governo Dutra foi o lançamento, em 1950, do Plano Salte. Este é considerado como a primeira tentativa de programação econômica no período pós-guerra, embora não tenha sido considerado um plano econômico completo, mas sim um programa de gastos públicos. O plano constituía na elaboração da política de gastos para setores prioritários (Saúde, Alimentação, Transportes, Energia) durante o período de 1950 a 1954.

Segundo Baer (1996), estimava-se gastar Cr\$19,9 bilhões nesse período, sendo que $\operatorname{Cr} \$ 2,6$ bilhões dessa quantia seriam destinados à saúde, $\operatorname{Cr} \$ 2,7$ bilhões para a modernização da produção e fornecimento de alimentos, $\operatorname{Cr} \$ 11,4$ bilhões para a modernização do sistema de transportes e $\mathrm{Cr} \$ 3,2$ bilhões para aumentar o potencial energético do país.

Os recursos para o Plano Salte proviriam em parte das receitas orçamentárias (2/3) e em parte de empréstimos (1/3). Porém, como o governo não conseguiu garantir estas fontes de financiamento, em menos de um ano o Plano Salte foi interrompido. Esta interrupção deveu-se às 
estimativas de receita e possibilidades de empréstimos excessivamente otimistas, uma vez que os planejadores econômicos não contaram com as dificuldades no Balanço de Pagamentos, que reduziram as possibilidades de financiar o plano com a queima de reservas. Também não contaram com o aumento da inflação e com os déficits orçamentários que dificultaram a concessão de empréstimos.

Para Baer (1996), a natureza do Plano Salte não era global, pois não dispunha de metas para o setor privado ou de programas que 0 influenciassem. Tratou-se basicamente de um programa de gastos que cobriu o período de um ano. O plano porém, teve como mérito chamar a atenção para outros setores da economia defasados em relação à indústria e que poderiam impedir um futuro desenvolvimento.

Com o encerramento do plano, em 1951, alguns dos projetos de obras públicas foram transferidos para outros departamentos do governo. Ainda durante 0 governo Dutra, tiveram continuidade programas importantes como os trabalhos de organização da Cia Hidrelétrica do São Francisco e a Superintendência do Plano de Valorização Econômica da Amazônia.

Como contribuição à prática de planejamento econômico deste período do pós-guerra considera-se ainda a formação da Comissão Mista Brasil - Estados Unidos (Missão Abbink), instituída em 1948. A comissão desempenhou um papel importante ao formular estudos, fazer recomendações e apresentar projetos que contemplavam vários aspectos da realidade econômica nacional.

Outro marco na história do planejamento no Brasil deste período é a criação do BNDE, em 1952, já no governo Vargas, que passa a fornecer suporte técnico e financeiro para a atuação do setor privado. Segundo Lacerda et al.(2000), a volta de Getúlio Vargas ao governo significou uma nova tentativa de superação nacionalista dos estrangulamentos do processo de substituição de importações e dos entraves à afirmação de um projeto nacional. Foram criados nesta época a Petrobrás, o Ministério da Saúde, o 
Fundo Nacional de Eletrificação, o Plano Nacional do Carvão, a Vale do Rio Doce e o Projeto Vale do São Francisco. Em 1956 foram realizadas reformas institucionais e criados instrumentos de política econômica que geraram um alargamento das funções do Estado na economia.

\subsubsection{O Plano de Metas (1956-1961)}

Em 1953 foi criado o Grupo Misto CEPAL/BNDE, a partir de um convênio firmado entre as duas instituições, com o objetivo de analisar o comportamento da economia brasileira no período de 1939 a 1953 e fazer projeções das principais variáveis macroeconômicas para os 7 anos seguintes. Essas projeções constituíram a primeira tentativa de planejamento global para a economia brasileira e criaram as bases para a elaboração do Plano de Metas.

As transformações da economia brasileira aprofundam-se a partir do Plano de Metas (1956/61), que é considerado como o primeiro no país a elaborar metas para o setor privado e a motivar os estudos agregativos da economia brasileira. As transformações desse período decorreram de vários fatores como a ampliação da participação política da sociedade, mudanças na distribuição ocupacional, intensificação do processo de urbanização e o populismo. Nesta época, o nacionalismo assume uma nova expressão: o desenvolvimentismo. As preocupações centrais da política econômica do governo Kubischek eram a industrialização, a expansão das oportunidades de emprego no setor urbano - dinâmico da economia e a transferência do exterior para o país das bases para o desenvolvimento autônomo. Para atingir tais objetivos foi necessário um levantamento das condições estruturais da economia do país para indicar os pontos de estrangulamento e os pontos de aceleração do crescimento. A partir destes levantamentos decorreria a programação das metas intersetoriais. 
Assim, além do trabalho desenvolvido pelo Grupo Misto CEPAL/BNDE, um volumoso levantamento estrutural da economia brasileira foi realizado pela Comissão Mista Brasil - Estados Unidos, constituindo as bases técnicas e institucionais para o governo, cujo símbolo era a construção de Brasília (crescimento de "50 anos em 5").

O Programa de Metas é então considerado como o primeiro esforço de instrumentalização de objetivos de política econômica e decomposição de metas em termos setoriais. Há, neste programa, o estabelecimento de metas específicas que atuaram como elementos de quantificação e decomposição de programas, mas também como instrumentos de acompanhamento e controle. As metas do programa abrangiam os setores de energia, transportes, alimentação, indústria de base e educação, onde a participação dos setores público e privado na execução das metas eram especificadas.

As prioridades do Programa de Metas eram o aumento das receitas de exportação, a manutenção de um sistema de seleção de importações em favor de bens de capital, a substituição de importações pela produção interna e o influxo de recursos produtivos externos. O programa admitia que "um ligeiro sopro inflacionário" incentivaria o investimento de poupanças privadas.

Alguns dos resultados mais importantes do Plano de Metas referemse ao setor de energia, com o aumento da potência elétrica instalada e da produção de petróleo. O setor de alimentação e indústria de base também apresentaram um significativo crescimento, assim como é marcante a implantação e o aumento da produção da indústria automobilística. Há também neste período, uma ampliação dos serviços de infra-estrutura e um avanço no processo de substituição de importações.

Segundo Tavares (1972), o Plano de Metas representou a primeira tentativa com certo êxito de planejamento em escala nacional, embora em termos setoriais e com todos os defeitos inerentes à falta de uma visão global e integrada da economia. Assim, o grande crescimento econômico 
alcançado na época teve conseqüências negativas como o aumento da dependência do capital estrangeiro, a elevação da dívida externa, o aprofundamento dos desequilíbrios regionais e a elevação do custo de vida.

Segundo Sandroni (2000), o Plano de Metas consistia de 30 metas para os diferentes campos de energia, transportes, alimentos, indústrias básicas e educação de pessoal técnico. Além disto, os projetos necessários para implementar essas metas eram listados juntamente com os seus respectivos custos. Para Sandroni (2000), o Programa de Metas apresentou as seguintes vantagens sobre os planos anteriores:

- metas bem definidas, em termos quantitativos, com estimativa dos recursos totais necessários;

- detalhamento das metas em projetos específicos;

- acompanhamento, sob a forma de relatórios sobre a execução do programa.

Entretanto, o Programa de Metas não apresentou uma visão global da economia. O plano foi um grande avanço sobre os planos anteriores, embora abrangesse apenas os setores estritamente econômicos e desse um tratamento limitado ou incompleto à política fiscal e monetária e aos setores governo e comércio externo.

Ainda no governo Kubitschek, foi lançado o Programa de Estabilização Monetária, que constituiu uma tentativa de conferir âmbito global ao planejamento durante essa administração. Este programa foi abandonado quando se evidenciou que a sua execução poderia comprometer a implementação do Plano de Metas. Este fato evidencia que a prioridade do planejamento econômico durante este período era o desenvolvimento, ao contrário do que passou a prevalecer a partir dos anos 80, cujos planos de estabilização tornaram-se a preocupação central do governo federal.

Algumas das metas do plano com os resultados previstos $\mathrm{e}$ realizados estão apresentados na tabela 1 : 
Tabela 1. Plano de Metas - previsão e resultados (1957-1961).

\begin{tabular}{lccc}
\hline \multicolumn{1}{c}{ Meta } & Previsão & Realizado & $\%$ \\
\hline Energia Elétrica (1000 kw) & 2000 & 1650 & 82 \\
Carvão (1000 ton.) & 1000 & 230 & 23 \\
Petróleo-Produção (1000barris/dia) & 96 & 75 & 76 \\
Petróleo-Refino (1000 barris/dia) & 200 & 52 & 26 \\
Ferrovias (1000 km) & 3 & 1 & 32 \\
Rodovias-Construção (1000 km) & 13 & 17 & 138 \\
Rodovias-Pavimentação (1000 km) & 5 & - & - \\
Aço (1000 ton.) & 1100 & 650 & 60 \\
Cimento (1000 ton.) & 1400 & 870 & 62 \\
Carros e Caminhões (1000 un) & 170 & 133 & 78 \\
Nacionalização (carros-\%) & 90 & 75 & - \\
Nacionalização (caminhões-\%) & 95 & 74 & - \\
\hline
\end{tabular}

Fonte: Lacerda et al. (2000)

\subsubsection{O Plano Trienal (1963-1964)}

Em 1961 o presidente Jânio Quadros criou a Comissão Nacional de Planejamento (COPLAN) que coexistiu por algum tempo com o Conselho de Desenvolvimento. Posteriormente, Celso Furtado, como Ministro Extraordinário para o Planejamento, preparou o Plano Trienal de Desenvolvimento Econômico e Social para o período de 1963 a 1965, já durante o regime parlamentarista do governo de João Goulart. O plano foi criado com os objetivos básicos de promover um desenvolvimento econômico rápido e estabilizar o nível de preços. Foram propostas as seguintes metas: 
- crescimento de $7 \%$ do PNB que deveria ser repassado aos salários reais com o objetivo de distribuir melhor a renda;

- promoção das Reformas de Base (principalmente a Reforma Agrária);

- refinanciamento da dívida externa do país;

- redução progressiva da pressão inflacionária, de modo que em 1965 a elevação do nível de preços não fosse superior a 10\%;

- redução das desigualdades regionais dos níveis de vida;

- melhoria da qualidade do ensino.

Para o governo da época, a realização destas metas só seria possível mediante o controle do processo inflacionário, que se tornou o objetivo prioritário do plano. A origem da inflação foi associada ao período de crescimento econômico de 1957 a 1961 com o aumento da participação do setor público na economia e também devido aos problemas estruturais do setor externo vinculados ao processo de substituição de importações.

O plano continha as seguintes metas para o controle inflacionário:

- redução do dispêndio público programado;

- captação de recursos do setor privado no mercado de capitais;

- política fiscal com aumentos progressivos da carga tributária.

O Plano Trienal possuía uma maior abrangência, programa e metodologia e modificou as concepções a respeito da política e programação econômica no Brasil. Este plano é considerado um marco histórico uma vez que este foi além da concepção plurisetorial, determinando linhas de ação com projeções globais da economia e tendo como objetivos amplas modificações estruturais como: a distribuição de renda, melhoria de recursos humanos, correção das disparidades regionais, organização do setor governamental e eliminação de entraves institucionais. Os tipos de investimento priorizados no Plano Trienal incluíam a ampliação da base de recursos naturais economicamente utilizáveis, o aperfeiçoamento do fator humano, investimentos sociais, estes da alçada do setor público, e 
investimentos estruturais e infra-estruturais como indicativos para o setor privado.

O Plano Trienal caracterizou-se ainda pelo seu caráter globalista e pelo fato de ter se ajustado ao quadro das motivações que levam o Estado a participar diretamente do processo de formação de capital em suplementação ao setor privado. Alinhou-se também às motivações decorrentes do processo de coordenação geral da economia, formulando diretrizes básicas para a orientação do crescimento econômico.

Contudo, Singer (1977) considera que o Plano Trienal não era um plano de desenvolvimento econômico e social do país, mas apenas uma plataforma de ação do governo federal.

Para Bresser Pereira (1998), o Plano Trienal não teve condições políticas para ser aplicado, dada a crise que o país atravessava no início dos anos 60 e que acabou culminando com o golpe militar em 1964. O Plano Trienal conseguiu sobreviver apenas até meados de 1963, quando todo o ministério de João Goulart foi substituído.

Segundo Sandroni (2000), com relação aos planos anteriores, o Plano Trienal apresentou a vantagem de partir de uma visão global da economia, mas a sua parte setorial não obedeceu a um esquema uniforme de apresentação e muitos dos seus objetivos não foram definidos quantitativamente, sendo apresentados sob a forma de diretrizes gerais.

Segundo Rossetti (1991), o Plano Trienal não descuidou da correção de desajustamentos, ao estabelecer objetivos para o controle progressivo da pressão inflacionária, para a atenuação dos custos sociais do crescimento econômico e para a redução das desigualdades regionais de níveis de vida. Contudo, o Plano Trienal não logrou êxito, como o Plano de Metas, devido principalmente às pressões exercidas por grupos populistas que impediam a implantação de medidas mais rigorosas de controle da inflação e às pressões exercidas por classes economicamente dominantes que tentavam impedir as Reformas de Base. 
Mesmo assim, o Plano Trienal contribuiu significativamente para o aprimoramento dos instrumentos de política econômica.

\subsubsection{O Plano de Ação Econômica do Governo (1964-1967)}

O Plano de Ação Econômica do Governo (PAEG) teve a sua implantação a partir da instauração do regime militar em 1964. Este surgiu como uma reação das classes conservadoras contra as posições reformistas contidas no Plano Trienal, porém atingiu níveis de agregação tão amplos quanto este. O plano procurava dar consistência às estratégias de reformas econômicas do primeiro governo militar, o governo do general Castelo Branco.

O PAEG assumiu uma posição menos reformista, com traços predominantemente liberais e propostas de caráter ortodoxo, mas sem abandonar a interferência governamental na economia, justificando a ação estatal contida no plano a partir das deficiências do sistema de preços. As deficiências apontadas pelo plano foram as seguintes: o livre jogo das forças de mercado não garante necessariamente a formação de um volume desejável de poupança, o sistema de preços nem sempre incentiva investimentos em setores essenciais como por exemplo, educação, transportes; e o sistema de preços não leva necessariamente a uma distribuição de renda razoável entre pessoas e regiões.

Apesar disso, segundo o PAEG, o Estado não elimina o papel da livre empresa e do mecanismo de preços, ele age apenas como regulamentador e tem um caráter meramente indicativo.

O PAEG foi elaborado pelos ministros Roberto Campos e Otávio Gouvêa de Bulhões com base na ortodoxia e no arrocho salarial, mas conseguiu realizar reformas importantes que os outros governos não puderam implantar, tais como: a reforma bancária, com a criação do Banco 
Central; a reforma do mercado de capitais; a criação do FGTS e do BNH e a instituição da correção monetária.

O fato mais relevante a ser comentado sobre o PAEG é o de que este marca um período de transição na vida política e econômica do país. Contudo, o PAEG não teve a pretensão de apresentar-se como um plano global de desenvolvimento, mas apenas como um programa de ação coordenada do governo no campo econômico. Estes traços liberais no entanto não correspondem às medidas implementadas no período de 1964 a 1966. Nesta época, o número de empresas estatais aumentou muito (em 1966 35\% das estatais existentes haviam sido criadas sob a vigência do PAEG).

As principais medidas do PAEG referem-se às destinadas ao controle da inflação que vinha aumentando muito desde 1959, chegando a atingir $90 \%$ em 1963. Estas medidas englobam a reforma tributária, com elevação da tributação para reduzir a renda disponível, a redução das emissões monetárias, o estímulo às exportações e redução das importações e um severo controle dos salários e dos juros. O diagnóstico da economia brasileira como uma economia inflacionária também gerou a criação das Obrigações Reajustáveis do Tesouro Nacional (ORTN) que permitiu ao governo a captação de recursos por via não inflacionária.

A inflação durante o período de vigência do PAEG foi diagnosticada como tendo componentes de demanda e de custos e, segundo Sandroni (1999), a inflação de custos foi localizada no processo de substituição de importações, incentivado por barreiras alfandegárias. Para este autor, o protecionismo permitia um aumento espiral nos custos dos setores substitutivos.

O PAEG atingiu seus objetivos no que se refere à redução da inflação, melhoria do saldo das contas públicas e recuperação das exportações agrícolas, não conseguiu porém, evitar a recessão e o aumento do desemprego. 
Segundo Tavares (1972), durante o período de 1964 a 1967 foram modificadas em profundidade as regras do jogo institucional. Não só do setor público, como no que se refere aos mecanismos de acumulação interna das empresas e aos esquemas de seu financiamento externo. Assim, a economia brasileira pôde voltar a crescer em novas condições de financiamento, mantendo aparentemente, o mesmo padrão estrutural de crescimento, apenas mais acentuadamente desequilibrado e concentrador. A natureza do problema central da acumulação naquele período de transição consistia na necessidade de transferir excedentes dos setores atrasados ou pouco dinâmicos para os de maior potencial de expansão.

O Plano previa uma taxa anual de investimento bruto de $17 \%$ do produto, que, associada a taxas anuais de depreciação de $5 \%$, crescimento populacional de $3,5 \%$ e a uma relação incremental capital-produto de $2: 1$, permitiria uma elevação da renda per capita de 2,5 \% a.a.

Neste período também foi realizada a Reforma Administrativa, na qual foram introduzidas modificações de largo alcance na estrutura do planejamento do país. Um dos objetivos da Reforma foi a institucionalização do planejamento governamental, firmando a norma de que a ação do governo obedeceria a programas gerais e setoriais de duração plurianual, elaborados através dos órgãos de planejamento, sob a orientação e coordenação geral do presidente da república. A Reforma estabeleceu que o planejamento constituiria um dos princípios fundamentais da administração federal, compreendendo a elaboração e atualização dos seguintes instrumentos básicos:

- plano geral do governo;

- programas setoriais e regionais de duração plurianual;

- orçamento programa anual;

- programação financeira de desembolso.

A Constituição de 24/01/67 estabeleceu a competência do Congresso Nacional para dispor sobre os "planos e programas nacionais, regionais e orçamento plurianuais" estipulando também que "as despesas de capital 
obedecerão ainda a orçamentos plurianuais de investimento, na forma prevista em lei complementar" e que "o orçamento consignará dotações plurianuais para a execução dos planos de valorização das regiões menos desenvolvidas do país."

Alguns dos resultados macroeconômicos durante o período de vigência do PAEG podem ser analisados na tabela 2:

Tabela 2. Brasil - variáveis macroeconômicas nos anos 60 .

\begin{tabular}{ccccc}
\hline Ano & PIB* & $\begin{array}{c}\text { Taxa de } \\
\text { Investimento* }\end{array}$ & Inflação* & Déficit Público* \\
\hline 1961 & 8,6 & 13,1 & 52,32 & \\
1962 & 6,6 & 15,5 & 73,81 & \\
1963 & 0,59 & 17,0 & 90,65 & \\
1964 & 3,4 & 15,0 & 57,09 & 332,21 \\
1965 & 2,4 & 14,0 & 38,45 & 2560,88 \\
1966 & 6,7 & 15,9 & 28,58 & 6089,07 \\
1967 & 4,2 & 16,2 & 24,23 & 8677,50 \\
\hline
\end{tabular}

Fonte: Instituto de Pesquisa Econômica Aplicada (IPEA) (2002)

PIB*- Taxa de crescimento;

Taxa de Investimento* - Formação Bruta de Capital Fixo/PIB;

Inflação* - variação do IGP- DI;

Déficit Público* - Gov. Federal e Banco Central (títulos). Em R\$ Milhões (deflator: IGP-DI). 


\subsubsection{O Plano Decenal (1967)}

Em 1966 tem-se a institucionalização de um sistema de programação econômica de longo prazo, para condicionar as ações dos agentes econômicos às diretrizes básicas formuladas por um órgão central de dimensionamento da economia. Este surge, diante da necessidade do planejamento de longo prazo, com o lançamento, em 1967, do Plano Decenal de Desenvolvimento Econômico e Social. O Plano Decenal incluía: orçamentos regulares com previsões de investimento para a administração central do governo federal, agências autônomas e sociedades de economia mista; orçamentos específicos para governos estaduais e municipais dentro dos setores examinados no plano e as projeções estimadas dos investimentos do setor privado .

O Plano Decenal foi além dos planos executados anteriormente por possuir um enfoque macroeconômico construído com base em um modelo de crescimento com projeções e testes de consistência interna.

Pela primeira vez procurou-se enquadrar os planos setoriais em um contexto mais amplo de políticas monetárias, fiscais e cambiais. Porém o plano não chegou a ser implementado. Segundo Ianni (1971), apesar de muito mais ambicioso que todos os outros planos governamentais, o Plano Decenal sequer começou a ser executado e foi arquivado "sob uma capa de silêncio". Em seu lugar foi implementado o Programa Estratégico de Desenvolvimento (PED) de 1968 a 1970. 


\subsubsection{O primeiro Orçamento Plurianual de Investimentos (1968- 1970)}

Um importante passo para a criação de uma estrutura de planejamento do setor público foi a elaboração do Orçamento Plurianual de Investimentos (OPI) e a aprovação do primeiro documento desse tipo para o período 1968/1969/1970.

Assim, o governo encaminhou ao Congresso Nacional, em março de 1968 a proposta do primeiro Orçamento Plurianual de Investimentos. Este documento desempenhou importante papel na execução do Programa Estratégico de Desenvolvimento (PED), retratando a programação dos investimentos setoriais da competência do Governo Federal, através da listagem de seus programas, subprogramas, projetos, atividades e respectivos custos, com a definição dos órgãos executores e especificação dos recursos orçamentários e extra-orçamentários, inclusive empréstimos contratados ou previstos, de origem interna ou externa.

O OPI elaborava estimativas de investimentos para um prazo mínimo de três anos. Segundo Garcia (2000), a idéia central do orçamento plurianual de investimento no Brasil é a de permitir a integração planoorçamento, a partir da concepção de que os investimentos constituem a base para o desenvolvimento econômico e social, compreendendo o plano de governo, o próprio OPI e o orçamento anual. O OPI cumpriu esse papel durante pouco mais de uma década (de 1968 ao início dos anos 80), após o que a escalada inflacionária retirou-lhe previsibilidade e capacidade orientadora (Garcia, 2000). 


\subsubsection{O Programa Estratégico de Desenvolvimento (1968-1970)}

O Programa Estratégico de Desenvolvimento (PED) foi elaborado durante o governo do presidente Costa e Silva, sob a gestão de Hélio Beltrão no ministério do Planejamento e Coordenação Geral, em junho de 1968, para o triênio $68 / 70$.

O PED continha como elementos fundamentais a criação de um programa de investimento nas áreas consideradas estratégicas, a programação de instrumentos financeiros e um conjunto de instrumentos de ação indireta sobre o setor privado. A proposição básica contida no PED era a definição da política de desenvolvimento econômico para o período de 1968 a 1970, tendo como objetivo principal o crescimento econômico. Procurou também corrigir as falhas ocorridas nos programas realizados pelos governos anteriores.

O ponto de partida para a elaboração do $P E D$, foi o diagnóstico dos dois problemas principais da economia brasileira da época: o esgotamento das oportunidades de substituir importações e a crescente participação do setor público na economia. Era portanto, indispensável a renovação dos setores dinâmicos, a consolidação da infra-estrutura e o incentivo a programas de expansão do poder de demanda. Também se mostravam imprescindíveis a política de distribuição de renda, mas preservando a capacidade de poupança, e a recuperação do atraso tecnológico.

Criou-se então um modelo para verificar a compatibilidade entre os objetivos e, a partir daí, definiu-se os objetivos setoriais de forma a compatibilizá-los com os objetivos globais. Isto porque o PED reconhecia o inter-relacionamento entre os setores público e privado e escolheu não ampliar as faixas de estatização do aparelho de produção. Assim, o PED limitou a ação governamental à ampliação da infra-estrutura econômica de apoio e ao fornecimento dos insumos básicos necessários para a dinamização de setores produtivos não tradicionais. Com isto, também 
estabeleceu bases para ampliar o acesso da empresa privada ao mercado interno de capitais e condições institucionais para o ingresso de capitais de risco.

O PED rompeu com a política macroeconômica do período anterior por considerar excessiva a pressão exercida pelo setor público sobre o controle da demanda agregada, uma vez que o programa considerou como errado o diagnóstico de inflação de demanda da época. Assim, adotou uma política mais voltada ao desenvolvimento, propondo uma nova estratégia para o desenvolvimento nacional.

Como objetivos básicos do PED podem ser citados a aceleração do desenvolvimento econômico, a contenção da inflação, o desenvolvimento social e a expansão das oportunidades de emprego. As principais metas referem-se à retomada dos investimentos, à expansão dos mercados interno e externo e à ampliação das áreas de atuação do BNDES financiando a petroquímica, a pesquisa e extração mineral, agropecuária, mecânica, comunicações, etc. Estes investimentos tornaram-se possíveis devido à recuperação da capacidade de financiamento do governo (melhoria das contas públicas em função do PAEG) e devido à criação de uma forma de captação de recursos não-inflacionária: a venda de títulos públicos, neste caso da ORTN.

Assim, em 1967, tem-se a adoção de uma política gradualista de controle da inflação em oposição ao tratamento de choque do período anterior. As principais fontes de crescimento econômico da época provinham da retomada do investimento público em infra-estrutura e do aumento das empresas estatais. Essa mudança na política macroeconômica favoreceu a retomada do crescimento econômico e possibilitou o surgimento do período conhecido como Milagre Econômico, com taxas médias de crescimento de $11 \%$ ao ano (1968 a 1973) e elevadíssimo crescimento industrial.

Segundo Furtado (1981), o Milagre Econômico foi a conjunção do uso de capacidade produtiva ociosa, melhora nos termos de intercâmbio, de grande prosperidade nos países industriais, principais importadores do 
Brasil, e de endividamento externo em condições excepcionalmente favoráveis.

Tabela 3. Milagre Econômico - resultados macroeconômicos.

\begin{tabular}{lllll}
\hline Ano & PIB* & Indústria* & Dívida Externa* & Inflação* \\
\hline 1968 & 9,8 & & 3780 & 20,14 \\
1969 & 9,5 & & 4403,5 & 19,44 \\
1970 & 10,4 & & 5295,2 & 20,32 \\
1971 & 11,34 & 11,81 & 8283,7 & 17,31 \\
1972 & 11,94 & 14,18 & 11463,9 & 14,91 \\
1973 & 13,96 & 17,03 & 14857,2 & 28,69 \\
\hline
\end{tabular}

Fonte: IPEA (2002)

PIB* - Taxa de crescimento;

Indústria* - Taxa de crescimento;

Dívida Externa* - US\$ (milhões);

Inflação* - Variação do IGP- DI.

\subsubsection{O Plano Metas e Bases Para a Ação do Governo (1970-1973)}

O plano subseqüente adotado pelo governo federal foi o Metas e Bases para a Ação do Governo (MBAG), durante o governo Médici, divulgado em outubro de 1970. O governo não pretendia criar um novo plano imediatamente e, assim, o MBAG complementou-se com outros dois documentos: o Orçamento Plurianual de Investimentos de 1971 a 1973 e o I Plano Nacional de Desenvolvimento Econômico e Social (1972 a 1974). Neste plano ficaria estabelecida a sistemática segundo a qual cada governo executaria o último ano do PND, com as correções que julgasse necessárias. 
O MBAG estabeleceu como prioridades nacionais para o período de 1970 a 1973 (auge do Milagre Econômico) as seguintes: investimentos em educação, saúde, saneamento, agricultura e abastecimento e o avanço no desenvolvimento científico e tecnológico.

O documento identificava como objetivo síntese o ingresso do Brasil no mundo desenvolvido até o final do século (Brasil, 1970). Este objetivo síntese incorporava os seguintes objetivos básicos:

- crescimento econômico com elevação da taxa de crescimento do produto real para no mínimo 7 a $9 \%$ a.a., evoluindo para $10 \%$ a.a.;

- expansão do emprego para a ordem de 3,3\% a.a.;

- controle da taxa de inflação;

- expansão das receitas de exportação;

- progresso social e melhoria na distribuição de renda;

- correção gradual de desequilíbrios regionais e setoriais;

- estabilidade política e segurança nacional.

\subsubsection{O primeiro Plano Nacional de Desenvolvimento (1972-1974)}

Em 15 de setembro de 1971 foi encaminhada ao Congresso, juntamente com o segundo Orçamento Plurianual de Investimentos, a proposta do I Plano Nacional de Desenvolvimento (I PND). O I PND definiu os seguintes objetivos nacionais:

- colocar o Brasil, no espaço de uma geração, na categoria de nação desenvolvida;

- duplicar, até 1980, a renda per capita do país (em comparação com 1969)

- expandir o PIB de Cr\$222,8 bilhões em 1972 para $\operatorname{Cr} \$ 314,5$ bilhões em 1974 (a preços de 1972); 
- investimentos nas áreas de siderurgia, petroquímica, transporte, construção naval, energia elétrica e mineração;

- prioridades sociais: agricultura, programas de saúde, educação, saneamento básico e incremento à pesquisa técnico- científica;

- ampliação do mercado consumidor e da poupança interna com os recursos do PIS e do PASEP;

- aumento da taxa de investimento bruto de 17\% em 1970 para 19\% em 1974;

Para isto, pressupunha a manutenção de taxas anuais de crescimento do PIB de 8 a 10\%; taxa de expansão do nível de emprego de $3,2 \%$, redução da taxa de inflação até o nível de 10\%; disseminação dos resultados do progresso econômico em termos sociais e regionais; estabilidade política e segurança interna e externa (Brasil, 1971).

O I PND foi elaborado durante a gestão do ministro do planejamento Reis Velloso, ainda no governo Médici, e coincidiu com a expansão cíclica do período do Milagre Econômico. Segundo Furtado (1981), o extraordinário crescimento da produção manufatureira brasileira, no período em que se convencionou chamar de "milagre", ocorreu sem que operassem modificações significativas na estrutura do sistema, ou sem que este alcançasse níveis altos de capacidade de autotransformação.

O I PND foi baseado no binômio político ideológico de segurança e desenvolvimento e representou uma ampla formulação do "modelo brasileiro de organizar o Estado e moldar as instituições". Os projetos de desenvolvimento do I PND seriam completados com o PIN (Programa de Integração Nacional), cujos objetivos eram a construção da Rodovia Transamazônica e colonização das regiões por ela cortadas; ampliar para 40 mil hectares a área irrigada do Nordeste e distribuir 70 mil títulos de propriedades rurais a posseiros e agricultores sem-terra.

Segundo Sandroni (2000), ao final do triênio 72/74, confirmou-se o elevado grau de execução do I PND, sobretudo na área econômica. Contudo, alguns projetos sociais tiveram um grau de execução bem abaixo do 
previsto. Dos 40 mil hectares estipulados para a irrigação no Nordeste foram irrigados apenas 5674 hectares. No saneamento básico, a rede de esgoto assegurou o atendimento a 500 mil pessoas em lugar dos 5 milhões constantes do I PND. No campo industrial o maior crescimento ocorreu no setor de bens de consumo duráveis o que acabou gerando um aumento nas importações de meios de produção. A inflação prevista para $10 \%$ a.a. atingiu os $35 \%$.

Para a avaliação dos resultados dos planos de desenvolvimento, foi implementado, em 1972, o Programa de Acompanhamento dos Planos Nacionais de Desenvolvimento que constituía a atividade permanente dos órgãos que integravam o sistema de planejamento e tinha por objetivo a avaliação da execução, revisão, complementação e aperfeiçoamento dos Planos Nacionais de Desenvolvimento e os respectivos instrumentos de controle e implementação.

Este trabalho era realizado por meio de:

- análise do desempenho total da economia e do comportamento de seus setores prioritários;

- avaliação do progresso alcançado na execução dos programas e projetos;

- identificação dos pontos de estrangulamento e obstáculos institucionais que dificultam a consecução das metas e a execução de programas e projetos.

Segundo Holanda (1983), pretendia-se fazer com que esse programa viesse a contribuir para a efetiva institucionalização de um sistema integrado de planejamento. Com base no programa, o relatório de acompanhamento do I PND relativo ao exercício de 1972, mostrou que das 34 metas setoriais mais importantes, 19 haviam se enquadrado na faixa de execução de 90 a 99\% e apenas 6 apresentavam um índice de execução de menos de $80 \%$.

O I PND, concedeu maior ênfase à indústria de bens de consumo duráveis, liderada pela indústria automobilística. Mas, apesar de haver um 
intenso crescimento econômico neste período, o plano acabou intensificando as distorções distributivas do país.

Tavares (1972) considera que o desenvolvimento do período se fez com graves pressões inflacionárias e com o aumento do desequilíbrio externo e das desigualdades regionais, embora não seja menos significativo, o fato de que o Brasil foi um dos poucos países da América Latina que conseguiu manter um ritmo de crescimento elevado na época e em que o processo de substituição de importações avançou até níveis de integração industrial maiores.

Tem-se assim, um grande avanço no processo de substituição de importações neste período. No entanto, em fins de 1973, a manutenção do ciclo expansionista dependeria cada vez mais de uma situação externa favorável. O Choque do Petróleo no final deste ano, veio tornar esta situação mais adversa e elevar a taxa de inflação interna. Diante da condição externa desfavorável e da diminuição da capacidade de financiamento do setor público, o modelo de crescimento do Milagre se esgotou e o governo se viu obrigado a optar entre uma política de ajustamento ou de financiamento.

A política de ajustamento causaria a contenção da demanda interna e evitaria que o choque do setor externo se transformasse em inflação permanente. A política de financiamento manteria o crescimento em níveis elevados, fazendo ajustes graduais de preços relativos, enquanto houvesse financiamento externo abundante. Inicialmente o governo da época escolheu o ajustamento, mas não conseguiu atingir os efeitos desejados. O governo então optou pela continuidade do processo de desenvolvimento lançando, em fins de 1974, o II PND. 


\subsubsection{O segundo Plano Nacional de Desenvolvimento (1975-1979)}

O segundo Plano Nacional de Desenvolvimento (II PND), do período de 1975 a 1979, constituiu a mais ampla e articulada experiência de planejamento no Brasil após o Plano de Metas. Foi elaborado durante o governo Geisel, pelo ministro do planejamento Reis Velloso, permanecendo em vigor até o primeiro ano do governo Figueiredo.

O II PND mudou a ênfase do desenvolvimento para a indústria de bens de capital, mas foi considerado um fracasso pois coincidiu com a fase de retração cíclica da economia. O plano buscava a preservação do modelo de desenvolvimento, admitindo que a continuidade do crescimento exigiria uma "reconstrução estrutural" com um esforço bem maior de acumulação por unidade adicional de produto. Assim, o II PND foi lançado apesar de o governo reconhecer as dificuldades para manter taxas de crescimento da ordem de $10 \%$, face à crise externa. Mesmo assim, optava pelo crescimento acelerado como "política básica".

O plano realizou alterações nas prioridades de industrialização brasileira: do setor de bens de consumo duráveis para o setor produtor de meios de produção, principalmente a indústria siderúrgica, máquinas, equipamentos e fertilizantes, sendo as empresas estatais o agente central destas transformações. O plano enfatizou a abertura na política externa, o mercado interno e a empresa privada nacional, o combate à inflação, a exploração do potencial hidrelétrico e a continuação do processo de substituição de importações. A principal meta do II PND era a manutenção da taxa de crescimento econômico em torno de $10 \%$ ao ano, com crescimento industrial em torno de $12 \%$.

Segundo Sandroni (2000), o II PND propunha transformar o Brasil em uma "potência emergente" deslocando-o do Terceiro Mundo para o espaço dos países altamente industrializados. Para isto propunha substituir importações, elevar as exportações e ampliar o mercado interno 
consumidor. $O$ investimento total seria de 1 trilhão e 750 bilhões de cruzeiros, para assim atingir um PIB da ordem de US $\$ 120$ bilhões e uma renda per capita de US\$1000,00. O nível de crescimento industrial deveria situar-se em torno de $12 \%$ a.a., as exportações deveriam crescer a $20 \%$ a.a. e a agricultura a 7\%. Quanto à ampliação do mercado consumidor, as diretrizes do II PND, não eram claras. Isto decorria da política salarial que reduzia o poder de compra dos assalariados. Assim, o crescimento do mercado interno estaria mais relacionado ao aumento populacional e à expansão do emprego.

Para Furtado (1981), os objetivos estratégicos do II PND podem ser sintetizados em 2 pontos: ampliar a base do sistema industrial e aumentar o grau de inserção da economia no sistema de divisão internacional do trabalho. Estes objetivos refletiam a percepção da necessidade de reestruturação do sistema produtivo, que requeria a elevação da taxa de investimento e, com intensidade ainda maior, da taxa de poupança. No entanto, os resultados da execução do plano ficaram bem aquém do esperado. De 1975 a 1979 a produção manufatureira cresceu a 6,8\% ao ano, a produção de bens de capital a $7 \%$ e a de bens de consumo duráveis a $7,4 \%$ ao ano.

O Conselho de Desenvolvimento Econômico (CDE) foi o principal órgão de implementação do plano, visando dar garantias de demanda e incentivos ao setor privado. Já a sustentação política do plano assentou-se no capital financeiro nacional, nas empreiteiras e nas oligarquias arcaicas. Desta forma, o governo buscava dar suporte ao plano, restando para isso equacionar a questão do financiamento.

Assim, as empresas estatais foram forçadas ao endividamento externo para cobrir o hiato de divisas. Além disso, houve uma estatização da dívida externa e ampliação da mesma devido, entre outros aspectos, à facilidade de obtenção de recursos no exterior. Esta facilidade decorria da ampla liquidez no mercado internacional. 
Para realizar o II PND, o Estado foi assumindo um passivo para manter o crescimento econômico e o funcionamento da economia (Vasconcellos et al., 1999). O endividamento do governo nesta época teve como conseqüência a deterioração da capacidade de financiamento do setor público na década de 80 , uma vez que socializaram-se todos os custos do II PND (aumento nos gastos sem criar mecanismos adequados de financiamento). $\mathrm{O}$ endividamento direto externo foi estimulado paralelamente ao aumento da dívida interna, impossibilitando progressivamente os grandes projetos governamentais. Este fato exigiu constantes revisões nas metas do II PND.

Segundo Sandroni (2000), durante a vigência do plano ocorreu uma variável não prevista: a necessidade de desaquecimento da economia. Este autor fez o seguinte balanço do plano: significativos avanços na geração de bens de capital, de energia, prospecção de petróleo e produção de álcool, mas o alcance dos objetivos estaria muito aquém do que foi traçado para o aumento do PIB, da renda per capita, das exportações e da ampliação do mercado consumidor.

A crise mundial está entre as causas da desaceleração do II PND, além dos limites estruturais do próprio plano. Segundo Lessa (1981), o II PND era impossível de ser implementado, em função do seu gigantismo e da crise econômica mundial, uma vez que se tratava de um verdadeiro projeto de Nação-Potência, não apoiado pelas bases de sustentação do regime militar. Já Castro (1985), considerava que os grandes projetos do II PND, pela sua complexidade e longo prazo de maturação teriam começado a produzir resultados visíveis somente a partir de 1983 e 1984, e as dificuldades acima mencionadas teriam apenas levado à diminuição do ritmo de investimentos a partir de 1976, mas não à sua paralisação total.

Para Bresser Pereira (1998), o plano não reconheceu que o Brasil (e - mundo) entravam naquele momento em uma fase de declínio ou desaceleração cíclica que tornavam inviáveis a maioria de suas metas. No 
entanto, este foi importante para estimular de forma definitiva a implantação da indústria de bens de capital no Brasil.

Tabela 4. Resultados macroeconômicos durante o II PND.

\begin{tabular}{cccccc}
\hline Ano & PIB* & Indústria* & FBCF/PIB* & Inflação* & $\begin{array}{c}\text { Dívida } \\
\text { Externa* }\end{array}$ \\
\hline 1973 & 14,0 & 17,03 & 20,4 & 28,6 & 14,9 \\
1974 & 8,2 & 8,4 & 21,8 & 27,8 & 20,0 \\
1975 & 5,1 & 4,9 & 23,3 & 41,2 & 25,1 \\
1976 & 10,2 & 11,7 & 22,5 & 42,65 & 32,1 \\
1977 & 4,9 & 3,1 & 21,4 & 38,7 & 37,9 \\
1978 & 4,9 & 6,4 & 22,2 & 53,9 & 52,1 \\
1979 & 6,8 & 6,8 & 23,3 & 100,21 & 55,8 \\
\hline
\end{tabular}

Fonte: IPEA (2002)

PIB* - Taxa de Crescimento;

Indústria* - Taxa de Crescimento;

Formação Bruta de Capital Fixo/ Produto Interno Bruto* - (Taxa de Investimento); Inflação* - Variação do IGP-DI;

Dívida Externa* - US\$ (Bilhões).

\subsubsection{O planejamento regional no Brasil}

O planejamento no Brasil foi utilizado largamente não apenas no âmbito federal, mas também em termos regionais. A experiência mais avançada neste sentido é a do Nordeste, em função dos trabalhos desenvolvidos pelo Banco do Nordeste do Brasil (BNB) a partir de 1954 e pela Superintendência do Desenvolvimento do Nordeste (SUDENE) a partir de 1959. Em 1955, o BNB apresentou ao governo federal o projeto 
Planejamento Global para o Nordeste, com ênfase na necessidade de realização de pesquisas sobre os problemas regionais, formulação de projetos, definição de prioridades e coordenação entre diferentes entidades governamentais.

Em conseqüência deste projeto, foi criado em 1959, junto ao conselho de desenvolvimento do governo Kubischek, um Grupo de Trabalho para o Desenvolvimento do Nordeste (GTDN), sob a coordenação do BNB. Posteriormente, este grupo foi sucedido pela SUDENE (1959). Em 1960, a SUDENE apresentou ao Congresso Nacional a proposta do seu I Plano Diretor que deveria cobrir o quinquênio 1961/65. Este projeto realizou um diagnóstico das origens do subdesenvolvimento regional e traçou as diretrizes gerais da política de desenvolvimento da região, que visava atingir os seguintes objetivos básicos:

- criação de novas oportunidades de emprego por meio da industrialização;

- melhoria no suprimento de alimentos da região mediante a expansão da fronteira agrícola, o aproveitamento mais racional das terras úmidas e a irrigação das zonas áridas.

A política de industrialização contida neste I Plano Diretor visava a transformação da estrutura industrial mediante a criação de indústrias básicas, altamente germinativas (siderúrgica), a reorganização e modernização do setor de indústrias tradicionais (principalmente a indústria têxtil algodoeira) e a exploração em larga escala das matérias-primas com excedentes estruturais de oferta, com o objetivo de estabilizar o setor primário.

Segundo Holanda (1983), dificuldades políticas retardaram a execução do plano, que de qüinqüenal transformou-se em anual. Contudo, o Congresso criou para a SUDENE um sistema de incentivos fiscais que mais tarde iria representar o mais importante instrumento para a execução da política de desenvolvimento da região. Posteriormente, três outro planos diretores da SUDENE foram aprovados pelo Congresso: II Plano Diretor 
(1963/65), III Plano Diretor (1966/68) e o IV Plano Diretor (1969/73). Em 1971 foi realizada uma revisão do IV Plano Diretor sob a forma do documento Plano de Desenvolvimento Regional (PDR) para atender à lei que tornava obrigatória a simultaneidade da elaboração e execução dos planos nacionais e regionais de desenvolvimento e determinaram a incorporação destes ao PND.

A política de desenvolvimento do Nordeste sofreu profundas alterações com a criação do Programa de Integração Nacional (PIN) de 1971 e do Programa de Redistribuição de Terras ao Nordeste (PROTERRA) de 1972 que implicaram em transferências de recursos do setor privado para o setor público e do Nordeste para a Amazônia. Mas, já a partir de 1974, houve a restauração da prioridade do desenvolvimento do Nordeste com a criação dos Fundos de Investimento do Nordeste (FINOR), juntamente com os Fundos de Investimento da Amazônia (FINAM) e com a criação do Programa de Desenvolvimento de Áreas Integradas do Nordeste (POLONORDESTE).

Modelo semelhante ao do Nordeste foi aplicado à Amazônia com a criação da Superintendência do Desenvolvimento da Amazônia (SUDAM), do I Plano Diretor da SUDAM (1967/71) e de programas como o Programa de Polos Agropecuários da Amazônia (POLOAMAZÔNIA) e o Projeto Carajás.

Outros órgãos de planejamento regional no Brasil da época eram a Superintendência do desenvolvimento do Vale do São Francisco (SUVALE), posteriormente transformada em Companhia de Desenvolvimento do Vale do São Francisco (CODEVASF), a Superintendência do Desenvolvimento da Fronteira Sudoeste (SUDESUL) e a Superintendência do Desenvolvimento do Centro Oeste (SUDECO). Além destes órgãos regionais, todos os Estados da Federação dispunham de órgãos de planejamento global e quase todos de entidades de planejamento setorial e organismos de financiamento. 


\subsection{A crise do planejamento no Brasil}

Segundo Holanda (1983), a implementação dos diversos planos econômicos no Brasil até o final dos anos 70 permitiu um considerável avanço no campo da pesquisa e do diagnóstico dos problemas econômicos do país, ao mesmo tempo em que as experiências de planejamento evoluíram de uma visão setorial e parcial da economia para uma concepção globalizada e integral do processo de desenvolvimento. Essas alterações evidenciaram a crescente complexidade do processo de planejamento em decorrência do desenvolvimento da economia, da eliminação dos pontos de estrangulamento mais evidentes e da redução das oportunidades de substituição de importações.

Contudo, a partir do final da década de 70, o país passa a enfrentar sérias dificuldades de financiamento que comprometem a sua capacidade de colocar em prática os programas de desenvolvimento econômico seguintes como por exemplo o III PND, O I PND-NR (Plano Nacional de Desenvolvimento da Nova República) e o PAG (Programa de Ação governamental).

Desta forma, a crise econômica da década de 80 provocou várias críticas ao padrão de intervenção estatal que prevaleceu no país desde os anos 40. Estas críticas referem-se, entre outros aspectos, à crise fiscal, à rejeição do planejamento econômico e à descrença na capacidade de planificação do governo.

Segundo Pereira (1998), a crise fiscal enfrentada pelo país a partir dos anos 80 colocou em questão a própria governabilidade do país. A impossibilidade do governo de atender à elevada demanda da sociedade por serviços ou bens públicos colocou em dúvida a competência, a necessidade e a própria legitimidade do Estado. A crise fiscal também veio comprovar a desorganização institucional criada pela incompatibilidade entre meios disponíveis pela sociedade e os fins do governo central. 
Segundo Tavares (1987), a perda da capacidade planificadora do Estado resultaria da crescente tendência à transnacionalização de interesses e estruturas econômicas, ou seja, do movimento de reorganização da economia mundial e do fracasso do autoritarismo. Assim, a crise do planejamento sobrepunha-se à reversão do ciclo industrial moderno, à ruptura do padrão de financiamento calcado no endividamento externo e à difícil transição democrática.

A partir do II PND, a expansão da produção induzida pelos estímulos e incentivos governamentais, começou a encontrar dificuldades de absorção pelo mercado. Um dos fatores responsáveis por esta dificuldade seria a incapacidade do setor produtivo estatal de manter a expansão econômica pela qual era responsável. Isto ocorria devido às dificuldades de autofinanciamento das estatais, uma vez que estas foram usadas como instrumento de política antiinflacionária, com o represamento de seus preços e tarifas. Outro fator apontado para a crise seria a inconsistência financeira do II PND, pois o seu principal vetor de financiamento, o BNDES, mostravase insuficiente face às dimensões do plano e, além disso, havia crise política e a falta de apoio popular ao plano.

Affonso (1989) considera que o aprofundamento da crise econômica e a fragilidade da transição institucional acentuavam a dificuldade de se efetuar uma aliança social e política capaz de direcionar o desenvolvimento do país. Isto porque o aprofundamento da crise fazia com que a articulação de um projeto de desenvolvimento passasse a pressupor algum tipo de ajustamento o que, por sua vez, significaria uma divisão de perdas entre os diversos setores da sociedade. Assim, a aliança desenvolvimentista foi dificultada pelas divergências sobre a transição institucional e sobre a abrangência da nova ordem política e social, ou seja, sobre quem sairia perdendo nesse ajustamento.

A crise econômica do início dos anos 80 e a dificuldade do governo em distribuir o ônus da mesma fez com que o centro da crise fosse 
deslocado do setor privado para o setor público, que passou a sofrer as conseqüências da deterioração em sua estrutura de financiamento.

Desta forma, o Brasil enfrenta, no início da década de 80, uma profunda crise fiscal, como conseqüência da ruptura do padrão de financiamento do setor público. Esta ruptura tem sua origem, além da própria recessão e inflação, no fato de que o Estado assumiu a maior parte do ônus da crise econômica e, além disto, tornou-se impossível manter indefinidamente um esquema de financiamento baseado em expressivo endividamento externo.

A retração no nível de atividades, o estrangulamento externo e o aumento da inflação somaram-se à falta de hegemonia política tanto no que diz respeito aos rumos do desenvolvimento quanto à extensão social da abertura política, tornando a atuação contracíclica do Estado uma atuação desnorteada.

Desta forma, dois fatores são normalmente apontados como os causadores da ruptura do padrão de financiamento do setor público. O primeiro é a desestruturação do financiamento fiscal. Esta decorreu da elevação dos incentivos e subsídios ao setor privado, da política de preços e tarifas públicas utilizadas para conter a espiral inflacionária, e da assistência generalizada do Estado à empresas com dificuldades financeiras. Esses fatores, que geraram a fragilização financeira do setor público, eram encobertos através do crescente recurso ao endividamento externo, que embora tenha possibilitado uma sobrevida ao crescimento econômico na segunda metade dos anos 70, agravou os desequilíbrios no anos 80 .

O segundo motivo é a elevação das taxas de juros no período. Esta piorava a situação fiscal do país que, diante da iminência de uma crise cambial, utilizava a elevação dos juros internos como forma de atrair capital especulativo e, para evitar crescimento excessivo da base monetária, recorria ao aumento da venda de títulos públicos. Assim, tem-se um processo de transformação da dívida externa em dívida interna. Além disso, houve a estatização da dívida externa pois os bancos ou empresas com 
dívidas no exterior fugiam do risco cambial fazendo depósitos no Banco Central que se responsabilizava pelo pagamento da dívida. As próprias empresas estatais passaram a se endividar externamente de forma progressiva e não mais para atender à demanda de investimentos reais, mas para atender à necessidade de rolagem da dívida.

Desta forma, quando ocorre o "choque dos juros" externos em 1979, o setor público encontrava-se em uma situação de extrema vulnerabilidade, com um elevado estoque de dívida externa, baixíssimo nível de poupança corrente e capacidade de autofinanciamento limitada. Está rompido o padrão de financiamento do setor público calcado no endividamento externo.

Assim, a partir do agravamento da crise nos anos 80, tem início uma retomada para restabelecer as funções convencionais dos mecanismos próprios de mercado. Passa a prevalecer a descrença da sociedade na capacidade do Estado de substituir os mecanismos de mercado (o que predominou a partir da $2^{a}$ Guerra Mundial). Inicia-se nesta época um processo de frouxidão nos sistemas de controle do Estado, reformas fiscais, redução da interferência do Estado e a privatização das empresas estatais. Percebeu-se que o modelo de desenvolvimento implementado após a $2^{a}$ Guerra Mundial, a substituição de importações, levou à constituição de uma estrutura industrial moderna, mas que este modelo se exauriu no final da década de 70.

Os programas econômicos de ajustamento adotados a partir da década de 80 não conseguiram modificar esta situação, pelo contrário, ampliaram os desequilíbrios existentes. O esforço de geração de superávits fiscais para honrar o serviço da dívida externa e fatores mencionados anteriormente como a queda na arrecadação tributária e a elevação da taxa de juros interna agravaram ainda mais a situação.

Os choques externos nos anos 70 e 80 (como os choques do petróleo e o choque dos juros internacionais) e a inadequação das medidas econômicas adotadas pelos sucessivos governos contribuíram para acelerar o fim do ciclo do modelo de crescimento econômico baseado na substituição 
de importações, na ação estatal e no endividamento externo. Outros fatores considerados para o fim do modelo são a aceleração inflacionária e a dificuldade de determinar perdas dentro da coalizão de poder que dava sustentação ao governo.

Segundo Pereira (1998), o Brasil seguiu uma política de substituição de importações com o objetivo de incentivar a indústria nacional até o final da década de 70. O esgotamento do modelo e o fechamento da economia brasileira levou a uma crescente defasagem tecnológica da indústria nacional, evidenciando a necessidade de uma mudança no modelo econômico.

No início dos anos 80, o ajustamento contracionista aliado à elevação da inflação, diminuiu as alternativas de financiamento do setor público. A opção que restou ao governo foi a utilização intensiva da dívida mobiliária, que passou a crescer muito a partir de 1982. Desta forma, parte significativa do ônus da crise econômica foi assumido pelo Estado enquanto as empresas privadas, por outro lado, ajustaram-se financeiramente. Estes fatores refletiram o comportamento do produto interno bruto, praticamente estagnado em todo o período; assim como o comportamento dos investimentos públicos, que caem drasticamente na década de 80 , com uma reversão somente a partir de meados dos anos 90. A crise que se instaura no país a partir do final da década de 70 pode ser visualizada na tabela 5 , baseada nos dados do IPEA. 
Tabela 5. Brasil - dados macroeconômicos (1979-1989).

\begin{tabular}{cccccc}
\hline Ano & PIB* & Inflação* & FBCF/PIB* & $\begin{array}{c}\text { Déficit } \\
\text { Público* }\end{array}$ & $\begin{array}{c}\text { Dívida } \\
\text { Externa* }\end{array}$ \\
\hline 1979 & 6,76 & 100,21 & 22,8 & 71447,3 & 55802,9 \\
1980 & 9,3 & 100,87 & 23,5 & 55194,1 & 64244,0 \\
1981 & $-4,25$ & 95,44 & 21,6 & 103129,6 & 73962,0 \\
1982 & 0,83 & 154,4 & 19,9 & 80382,1 & 85303,0 \\
1983 & $-2,93$ & 270,67 & 17,2 & 50461,3 & 93556,0 \\
1984 & 5,4 & 225,52 & 16,3 & 85682,4 & 102039,4 \\
1985 & 7,85 & 142,12 & 16,4 & 121741,6 & 105124,9 \\
1986 & 7,48 & 224,83 & 18,7 & 323887,7 & 111044,4 \\
1987 & 3,52 & 684,62 & 17,8 & 455856,1 & 121173,7 \\
1988 & $-0,06$ & 1319,87 & 16,9 & 337938,4 & 114435,1 \\
1989 & 3,16 & 2740,22 & 16,6 & 327800,1 & 115506,1 \\
\hline
\end{tabular}

Fonte: IPEA (2002)

PIB* - Taxa de crescimento;

Inflação* - Variação do IGP-DI;

Formação Bruta de Capital Fixo/ Produto Interno Bruto* - (Taxa de investimento);

Déficit Público* - Dívida interna em títulos (R\$ Milhões) - governo federal e BACEN (Deflator: IGP-DI);

Dívida Externa* - US\$ (Milhões) 


\section{O Planejamento no brasil pós - 1979}

O "desajuste" do setor público repercutiu negativamente sobre a sua capacidade de planejamento uma vez que, com o agravamento da crise econômica, no começo dos anos 80 , o tema política industrial foi totalmente retirado do foco das atenções governamentais.

Apenas a partir de 1984, alguns economistas passaram a trabalhar na elaboração de diretrizes gerais para uma política industrial. As sugestões destes economistas encontram-se no documento da Comissão para o Plano de Governo (COPAG) de janeiro de 1985. Os principais aspectos do documento referem-se ao papel crucial atribuído ao Estado como sinalizador e promotor das transformações necessárias, à definição de empresa privada nacional como objeto de atenção privilegiada; à necessidade de se promover a modernização do sistema produtivo de modo a coaduná-lo com os rumos da revolução tecnológica em escala mundial, à definição da microeletrônica, da química fina, da mecânica de precisão e da biotecnologia como setores estratégicos e à importância atribuída à reserva de mercado para a consecução dos vários objetivos assinalados (Brasil, 1985a).

O primeiro governo civil brasileiro, após o regime militar, defrontouse no início dos anos 80 com graves problemas que dificultaram a sua capacidade de planejamento. Entre estes problemas considera-se como elemento decisivo a falta de uma diretriz hegemônica que impulsionasse as ações econômicas num mesmo sentido. Esta falta de um direcionamento gerou, por exemplo, a coexistência de três planos nacionais de mesma 
temática e abrangência temporal como o I Plano Nacional de Desenvolvimento da Nova República (I PND-NR), de 1985, o Plano de Consistência Macroeconômica (PCM), de 1987, e o Programa de Ação Governamental (PAG), de 1987.

Os três planos mostravam preocupações comuns como a necessidade de crescimento econômico, o equacionamento das contas externas, a redução da inflação e do déficit público. Contudo, as linhas de ação dos planos diferiam bastante. Por exemplo, enquanto no plano externo - PCM propunha a elevação dos saldos comerciais como forma de garantir uma renegociação da dívida externa sem comprometer o crescimento do país, o I PND-NR enfatizava a mudança no padrão de negociação da dívida externa e a necessidade de reduzir as transferências de recursos ao exterior. O PCM enfatizou a recomposição das contas públicas e a necessidade de elevar a carga tributária com uma estrutura fiscal progressiva. O PAG possuía uma maior abrangência incorporando uma série de programas sociais, mas a generalidade de seus objetivos dificultava a compatibilidade do plano com as metas do PCM.

Esta superposição de planos resultou em uma implementação apenas parcial, que dependia da importância política dos seus elaboradores, e gerou também a descontinuidade das propostas de política industrial, assim como as dificuldades de colocá-las em prática.

Assim, observa-se que nos anos 80, a economia brasileira mostrou uma realidade sobre o planejamento extremamente confusa, em que coexistiram vários planos oficiais e distintos, que com maior ou menor abrangência cobriam o mesmo período, não se compatibilizavam e foram sendo rapidamente superados por fatos econômicos que contrariaram os prognósticos e objetivos deles constantes.

A necessidade de uma política econômica ajustada à política industrial pressupunha a renegociação dos termos de financiamento da dívida externa, a implantação de uma política monetária e fiscal não 
contracionista, uma reforma do setor público e do setor financeiro privado e a descompressão da massa salarial.

Mas, apesar deste discurso estar apoiado por parcelas importantes do empresariado nacional, a primeira formulação de uma política industrial da "Nova República" não chegou a ser concretizada. Os motivos apontados seriam as contradições internas do projeto modernizante decorrentes da dificuldade de conciliar o objetivo de fomentar o desenvolvimento de setores estratégicos com o de modernizar o sistema produtivo em geral, o "endurecimento" da comunidade financeira internacional em relação à dívida externa, às pressões dos Estados Unidos contra a reserva de mercado de informática e, principalmente, ao fracasso do Plano Cruzado.

Em junho de 1987 o governo anunciou a "Nova Política Industrial" que se contrastava com a política anterior. Nesta acentuava-se a necessidade de se ampliar o grau de abertura da economia, de se eliminar os entraves burocráticos à atividade empresarial e do tratamento mais liberal ao capital estrangeiro.

A história mostra que nem sempre o desenvolvimento industrial dos diversos países foi incentivado por medidas específicas de política econômica. Nos países de industrialização retardatária, no entanto, a importância de instrumentos de política industrial é reconhecidamente fundamental.

Desta forma, a não existência de uma política industrial explícita nos anos 80 e início dos anos 90, reflete uma transição na qual o papel do Estado como promotor do desenvolvimento vem sendo repensado. No entanto, é importante ressaltar que todos os países adotam medidas de estímulo à indústria, mesmo que o seu uso não seja explícito (Bonelli, 1994).

Essa mudança no papel do Estado associou-se às várias dificuldades de implementação dos planos de desenvolvimento nacional, e consequentemente, de uma efetiva política industrial no Brasil a partir dos anos 80 . Um dos fatores responsáveis por esta dificuldade é a multiplicidade 
orçamentária que marcou a institucionalidade do setor público brasileiro durante quase toda a década de 80 . Outros fatores seriam: a tensão crescente entre as políticas macroeconômicas, sobretudo a monetária e o planejamento e a descrença quanto à capacidade do Estado liderar a promoção do desenvolvimento econômico, diante dos sucessivos fracassos das políticas de estabilização.

Além disto, o planejamento econômico a partir do final dos anos 80 passa a atuar de acordo com o mandato da Constituição de 1988 e o ambiente político à essa época era bastante conturbado. Para Garcia (2000), a institucionalidade do planejamento público encontrava-se em visível deterioração, fato este associado à crise do regime militar; ao acelerado esgotamento do modelo de financiamento (interno e externo) do investimento público e do privado; à conclusão do processo de substituição de importações, sem que se afirmasse um outro padrão de acumulação sob a vigência da chamada revolução tecnológica; e à insuficiência do planejamento normativo e economicista praticado pelo governo.

"O planejamento normativo foi relativamente eficaz em lidar com uma sociedade menos complexa, social e politicamente contida pelo autoritarismo vigente, e conduziu um projeto de modernização conservadora da economia nacional, orientado para levar o país a concluir a $2^{\text {a }}$ Revolução Industrial, sem contudo construir um grande e mais homogêneo mercado de massa" (Garcia, 2000, p.8).

O planejamento normativo obteve expressão com os Planos Nacionais de Desenvolvimento Econômico, mas já era praticado no PAEG, no Plano Decenal, no PED e no Metas e Bases para a Ação do Governo, anteriores ao ciclo dos PND's (I, II, III e I da Nova República). O chamado "viés economicista" se manifestava ao se considerar o planejamento apenas como uma técnica para racionalizar a aplicação exclusiva de recursos econômicos, entendidos como os únicos utilizados no processo de governar. Assim, nos planos posteriores a 79, também foram ignorados os recursos 
políticos, organizacionais, de conhecimento e informação, entre outros, necessários à condução de uma sociedade mais complexa.

Segundo Garcia (2000), os vinte anos (1964/1984) de autoritarismo e economicismo deixaram marcas profundas, que influenciaram as visões sobre o tema por parte de intelectuais, técnicos e políticos. Para ele, a nova Constituição não conseguiu superar a concepção normativa e reducionista do planejamento governamental, que foi concebido ignorando-se a nova e complexa realidade política, social, cultural e econômica. Não foram considerados também os avanços do conhecimento sobre os processos de governo e as novas teorias e práticas de planejamento público moderno, que buscam integrar as dimensões e os recursos políticos, econômicos, cognitivos, organizativos e outros em uma perspectiva estratégica.

Apesar de todos estes fatores, observa-se que ao longo de várias décadas houve uma contínua e rica experiência de planejamento no Brasil. Neste processo, alguns planos não saíram do papel, mas grande parte deles sofreu implementação parcial ou total, pelo menos até o III PND. De um modo geral, o planejamento no Brasil incorporou as seguintes características: tendência à abrangência; institucionalização do planejamento; compatibilidade com a economia de mercado; mínima participação de setores externos ao governo; importância maior do fator social; identidade de objetivos a partir de 1964, com estratégias e diretrizes similares; prazos curtos e ausência de um plano de perspectivas, com exceção do Plano Decenal e a tendência ao abandono de metas rígidas, com o uso de indicadores básicos.

O processo de planejamento ganhou experiência e refinamento na produção de planos, mas estes perderam credibilidade a partir da década de 80. Segundo Lopes (1990), a esperança nos resultados dos planos superava as suas reais possibilidades. O planejamento foi visto como algo infalível, que poderia e deveria solucionar todos os problemas de cada país, individualmente, e do mundo, como um todo. Esse erro de concepção e esse 
excesso de otimismo também prejudicaram a avaliação dos resultados do planejamento no Brasil.

Assim, houve o sucesso do Plano de Metas, depois o fracasso do Plano Trienal e, na fase de expansão econômica, um grande otimismo com o PED, o I PND e o Metas e Bases. Houve otimismo até com o II PND, mesmo com a economia já em processo de retração. No entanto, a partir do III PND, a deterioração da economia como um todo, os surtos de inflação, os anos de depressão e os "choques heterodoxos" juntaram-se à perda de substância do processo de planejamento.

No plano se concentravam as esperanças de desenvolvimento do país e, uma vez frustradas, estas geraram violentas críticas. Desta forma, a partir dos anos 80 , passa-se para um estágio de profundo desencanto com o planejamento, de dúvidas quanto às suas qualidades e de ceticismo quanto ao seu potencial.

Além disto, começou-se a questionar se o planejamento consistiria realmente no instrumento adequado para corrigir os desequilíbrios estruturais dos países pobres.

"De um lado, levantou-se uma perturbadora dúvida:

o sucesso do planejamento depende de certas pré-condições

- como racionalidade, estabilidade política, implementação eficiente, etc. - que a prática tem demonstrado inexistirem. O fracasso do plano seria, então, axiomático, óbvio, fatal. Mais ainda, o planejador acabaria sendo controlado pelas forças que tentou subjugar" (Lopes, 1990, p. 53).

Nos anos 80, chega-se ao ponto de o tema planejamento praticamente não ser abordado na área acadêmica. O debate passa a se referir mais à opção dirigismo econômico ou economia de mercado, fazendo menção ao plano como marco histórico ultrapassado. Questiona-se se o planejamento pode induzir o desenvolvimento ou se este decorre de outros fatores, tais como mudanças nos fatores de produção, avanços no conhecimento, alocação mais eficiente de recursos e economias de escala. 
Assim, observou-se o crescimento da importância atribuída ao planejamento desde o Plano Salte até o II PND e, posteriormente, o processo entrou em uma crise que perdurou durante toda a década de 90. Segundo Lopes (1990), o período que se inicia a partir do III PND indicava a falência do planejamento no Brasil como processo efetivo e um descrédito quanto ao seu potencial, tanto como instrumento de ação governamental quanto como indutor da ação privada.

No entanto, atualmente, parece haver uma gradual recuperação da valorização do planejamento como instrumento da ação governamental. Isso pode ser visualizado na tendência da crescente importância atribuída aos planos plurianuais. Do primeiro PPA, de 1991, ao Avança Brasil, de 2000, notam-se consideráveis progressos em termos de valorização do planejamento e de um esforço maior para a eficácia na implementação e no alcance de objetivos. Segundo Tavares (2000), o Brasil possui uma experiência de planejamento ímpar na América Latina que vem desde os anos 50, foi aperfeiçoada anos 80 e 90 e está passando por uma nova fase de aprofundamento com a introdução de novas técnicas de planejamento e gerenciamento.

\subsection{Os planos de desenvolvimento após o II PND}

Nesta fase da pesquisa, buscou-se identificar e descrever os planos de desenvolvimento elaborados no país após o II PND. Procurou-se também realizar uma avaliação dos planos e do grau de implementação destes.

Foram identificados os seguintes planos de desenvolvimento elaborados após o II PND: o III PND, o I PND - NR e o PAG (Plano de Ação Governamental), anteriores ao mandato constitucional de 1988, e o PPA (91), o PPA (96) e o PPA (2000) que foram criados já atendendo às 
mudanças no planejamento propostas pela Nova Constituição que instituiu o Plano Plurianual.

\subsubsection{O terceiro Plano Nacional de Desenvolvimento (1980 - 1985)}

O terceiro Plano Nacional de Desenvolvimento foi elaborado em 1979, em plena crise econômica, durante o governo do presidente Figueiredo, pelo ministro Delfim Neto que, paradoxalmente, era considerado um descrente do planejamento econômico.

O plano foi projetado para o período de 1980 a 1985, embora tenha sido interrompido já no segundo semestre de 1980. Neste período, já não existia o clima de "euforia desenvolvimentista" que marcou os PND's anteriores. Segundo Giacomoni (1996), o país começava a sofrer as conseqüências da crise econômica internacional e o governo federal, alegando que a instabilidade impedia qualquer programação de mais longo prazo, passou a governar com medidas de curto e curtíssimo prazo.

O III PND reconheceu como setores prioritários da economia brasileira a agricultura e o desenvolvimento de novas fontes de energia. Quanto aos seus objetivos, O III PND pouco se diferenciava dos planos anteriores mantendo como objetivo síntese a construção de uma sociedade desenvolvida, livre, equilibrada e estável, em benefício de todos os brasileiros, no menor prazo possível. Segundo o documento oficial do III PND, foram considerados os seguintes objetivos prioritários:

- acelerado crescimento da renda e do emprego;

- melhoria da distribuição da renda, com redução dos níveis de pobreza absoluta e elevação dos padrões de bem-estar das classes de menor poder aquisitivo;

- redução das disparidades regionais;

- contenção da inflação; 
- equilíbrio do Balanço de Pagamentos e controle do endividamento externo;

- desenvolvimento do setor energético;

- aperfeiçoamento das instituições políticas.

No entanto, estes objetivos não foram alcançados, até porque não houve qualquer implementação do plano.

Na realidade, o III PND não pode ser considerado como um plano de desenvolvimento, mas como uma simples declaração de intenções pelo governo. Segundo Lopes (1990), o plano foi preparado apenas para o cumprimento de uma determinação legal, sob a égide de um ministério cujo comandante não via qualquer utilidade prática no processo de planejamento e, sendo assim, o III PND viu-se logo relegado ao esquecimento.

Para Bresser Pereira (1998), o III PND refletiu não apenas a crise econômica como também a própria crise do governo, incapaz de formular um plano de ação coerente.

Holanda (1983), considera que o III PND foi influenciado pelo impacto do choque do petróleo e dos juros internacionais que tornaram precárias quaisquer projeções econômicas. Para este autor, o plano se caracterizava como um documento basicamente qualitativo, definindo diretrizes, critérios e instrumentos de ação. E, em função das incertezas e das restrições decorrentes da crise energética, da dívida externa e das pressões inflacionárias não apresentou metas quantitativas.

Assim, o III PND marca o fim do processo de planejamento como efetivo instrumento de controle da política econômica do país. Foram apontados os seguintes motivos para o fim do processo:

- a saída do ministro Reis Velloso da SEPLAN (Secretaria de Planejamento) e a ascensão de Delfim Neto, representando uma mudança de mentalidade, uma vez que Velloso sempre foi um grande defensor do planejamento, enquanto Delfim Neto não depositava o mesmo crédito no processo; 
- a distância entre os números previstos no II PND e os realizados, gerando uma reação contra o planejamento;

- as dificuldades enfrentadas pelo segundo choque do petróleo e pela alta das taxas de juros internacionais limitando as funções do III PND.

Segundo Lopes (1990), o III PND foi preparado, aprovado e publicado apenas devido à imposição legal e, à época em que o plano deveria estar sendo implementado, a convicção geral era de se tratar de um documento de reduzida utilidade em face dos desafios enfrentados pela economia brasileira.

\subsubsection{O primeiro Plano Nacional de Desenvolvimento da Nova República (1986 - 1989)}

A Nova República encontrou, em 1985, apesar da grave situação de endividamento, uma posição de relativo ajuste após as crises de 1981 a 1983, graças aos pesados investimentos em energia e à recuperação dos superávits na balança comercial. A recuperação do crescimento, no entanto, associou-se à explosão das taxas de inflação ocasionando o Plano Cruzado em 1986.

O Plano Cruzado gerou uma economia com preços congelados por tempo excessivo, provocando desabastecimento geral e desequilíbrio dos fatores de produção, que levaram ao abandono do plano e a um novo surto inflacionário em 1987. Segundo Lopes (1990), este conturbado cenário deflagrou a decadência do processo de planejamento que o Brasil vinha desenvolvendo há décadas. Neste sentido, o lançamento do I Plano Nacional de Desenvolvimento da Nova República (I PND-NR) acentuou a crise do planejamento para o desenvolvimento no Brasil, presente desde o III PND. 
Este primeiro plano de desenvolvimento do governo de José Sarney foi publicado pela SEPLAN, com metas para o período de 1986 a 1989 e elaborado sob a coordenação do ministro João Sayad.

O I PND-NR se concentrou nos seguintes aspectos:

- crescimento econômico;

- combate à pobreza, às desigualdades e ao desemprego;

- educação, alimentação, saúde, saneamento, habitação, previdência e assistência social;

- justiça e segurança pública.

Quanto à parte econômica o I PND-NR evitou quantificações que pudessem representar compromissos mensuráveis. Enfatizou, principalmente, a mudança no padrão de negociação da dívida externa e a necessidade de reduzir as transferências de recursos ao exterior. Quanto ao setor público, priorizou a reestruturação do aparelho estatal por meio de medidas que iam desde a privatização seletiva de empresas estatais à reforma administrativa.

Segundo Lopes (1990), o I PND-NR representou um inútil exercício, da mesma forma que seu antecessor, e não foi sequer considerado como instrumento de suporte ou indicador de tendências seja pelo governo, seja pelo setor privado.

No entanto, a argumentação dos mentores do plano era a de que este se diferia dos anteriores, assim como as condições da economia brasileira nos anos 80 se diferiam das condições da década anterior. Esta diferença apresentava-se na própria concepção do plano:

"Em virtude da circunstância em que vivemos no campo econômico-social e devido à nova orientação do governo sobre as funções do setor público, associada ao decisivo estímulo para que o setor privado assuma o papel de liderança no processo de crescimento, este não é um plano de investimentos públicos, nem uma proposta acabada 
e compulsória de direcionamento dos investimentos empresariais" (Brasil, 1985b).

Segundo Giacomoni (1996), em função das dificuldades de reorientar a questão financeira no âmbito do setor público e dos problemas de administração da dívida externa e interna, o país, ao longo desse período, conviveu com inúmeras crises que se refletiram na substituição de ministros da área econômica e na adoção de medidas de curtíssimo prazo. Estes fatos dificultaram o planejamento de médio e longo prazo no país e, portanto, a implementação do I PND-NR.

\subsubsection{O Plano de Ação Governamental (1987-1991)}

O Plano de Ação Governamental (PAG) lançado em 1987, durante o governo Sarney, apresentou a estratégia de desenvolvimento para o país no período de 1987 a 1991. O plano foi elaborado durante a gestão de Aníbal Teixeira no Ministério do Planejamento e propunha a viabilização dos objetivos de longo prazo no país, vistos como o crescimento do produto e do emprego.

Segundo os Documentos da Presidência da República, o plano tinha como prioridades a eliminação dos desequilíbrios sociais, o desenvolvimento tecnológico e a formação de recursos humanos. O PAG constituiu um plano qüinqüenal com programas setoriais de desenvolvimento. As diretrizes econômicas preconizadas no programa eram a geração de 8 milhões e 400 mil novas ocupações em 5 anos; a ênfase especial nos investimentos na área social, o desenvolvimento do mercado interno e a expansão das exportações (Brasil, 1986).

Os principais objetivos do plano eram: o crescimento do PIB médio entre 5 e 7\% ao ano entre 1987 e 1991; o crescimento da agricultura como resultado da implantação de programas de irrigação, apoio à agroindústria e 
outros programas de incentivo; e o crescimento industrial a 6,5\% ao ano, com ênfase especial nos setores de insumos básicos e de alta tecnologia.

O PAG destacou quatro grandes segmentos:

a) geração de empregos a taxas suficientes para atender aos contingentes de trabalhadores da PEA e aos desempregados;

b) efetivação dos programas de gastos públicos em infra-estrutura social, especialmente voltada para os setores de saúde e saneamento;

c) preservação dos salários reais dos trabalhadores e concessão de aumentos reais para as classes mais baixas dos assalariados;

d) possibilidade de acesso aos frutos do progresso e do desenvolvimento pelos segmentos menos favorecidos da população.

Desta forma, o PAG buscava intensificar a política de investimentos em pólos de desenvolvimento que demonstrassem efetiva viabilidade; articular inter-regionalmente os gastos públicos para potencializar os benefícios da política regional e compatibilizar os programas especiais com as metas setoriais e sociais.

Após apontar os objetivos econômicos e sociais, o PAG procurou restabelecer a confiança aos diversos segmentos da sociedade nas diretrizes e metas governamentais de médio e longo prazo, transferir à iniciativa privada a liderança do processo de investimento, racionalizar os gastos públicos e otimizar as alocações de recursos em projetos prioritários.

Apesar deste documento criado pelo governo apresentar uma proposta de planejamento melhor elaborada para o período que o I PND-NR, o PAG não foi mais adiante que o plano anterior.

Segundo Lopes (1990), o PAG vem a ser o exemplo mais primoroso de um processo de planejamento que alcança a elegância mas é despido de qualquer relevância. Para este autor, na época de sua publicação, o plano já encontrou suas metas e prioridades comprometidas, de um lado, pelas restrições orçamentárias limitadoras dos investimentos públicos e, de outro, 
pela retração da empresa privada ocasionada pela progressiva desestruturação da economia como um todo.

\subsection{O novo modelo de planejamento - os planos plurianuais}

\subsubsection{O PPA (1991-1995)}

De acordo com a Constituição de 1988, o presidente da república deve encaminhar ao Congresso Nacional, até o dia 31 de agosto, suas metas de governo para serem aplicadas no período que vai do segundo ano da gestão ao primeiro ano do governo seguinte. Desta forma, o governo do presidente Fernando Collor de Mello apresentou, em 1990, as propostas para o Plano Plurianual de Investimentos, para a Lei de Diretrizes Orçamentárias e para o Orçamento que vigorariam de 1991 a 1995.

Com o novo governo, foi realizada uma reforma políticoadministrativa destacando-se a fusão da Secretaria de Planejamento e Coordenação da Presidência da República (SEPLAN-PR) com o Ministério da Fazenda e com o Ministério da Indústria e Comércio em um Ministério da Economia, Fazenda e Planejamento (MEFP). Houve também a redução do Instituto de Planejamento Econômico Social (IPEA) à condição de Instituto de Pesquisa Econômica Aplicada, vinculando-o não à área de planejamento do MEFP, mas à de política econômica, o que representou um retrocesso ao sistema de planejamento governamental brasileiro.

Segundo Garcia (2000), essas mudanças conceituais e organizacionais introduzidas em 1990 fizeram o planejamento governamental voltar aos anos 60. Segundo este autor, a equipe que assumiu o MEFP era integrada por economistas acadêmicos convictos do "sublime" poder do mercado e minimizadores da relevância do Estado, onde 
o planejamento consistia em um instrumento ultrapassado e a política econômica respondia pelo que de mais relevante podia fazer o governo.

Nessas circunstâncias, o PPA seria entendido como algo não muito diferente de um Orçamento Plurianual de Investimento (OPI), o que, na realidade, acabou acontecendo.

Segundo Garcia (2000, p.11),

"o primeiro PPA foi elaborado como um OPI ampliado (em tempo e em tipos de despesa), sem estar suportado por um projeto de governo preciso para o qual fizesse a mediação com os orçamentos anuais. Sua elaboração deu-se sob enorme improvisação, pois os responsáveis por sua redação trabalhavam sem contrato regular com os dirigentes máximos, que, por sua vez, apenas declaravam intenções vagas, anunciavam programas com nomes pomposos e sem substância. Muitas palavras de ordem, sem indicação de como realizá-las na prática."

Assim, o plano apenas cumpriu as exigências constitucionais, sendo apresentado ao Congresso Nacional e aprovado sem discussão e novas propostas. "Publicado pelo Poder Executivo, recebeu bonita encadernação e galgou prateleiras para se empoeirar. Não se tornou um orientador da ação governamental" (Garcia, 2000, p.12).

Além disto, havia uma forte dissociação entre o PPA e as verdadeiras intenções do governo, o que se tornou claro em pouco tempo. Já no primeiro semestre de 1992 foi iniciada uma revisão do plano, para o triênio 1993/95, concluída com a aprovação da Lei no 8446, de 21/06/92 que foi praticamente ignorada, dado que, à mesma época, tinha início o processo de denúncias de corrupção no governo federal.

O plano era mais voltado à programação da ação do governo, sem as características de plano de desenvolvimento econômico-social como os anteriores. As propostas do plano não chegaram a ser totalmente implementadas devido à recessão, gerada pelo Plano Collor de estabilização, 
e devido, principalmente, à crise política do governo que acabou culminando com processo de impeachment e o afastamento do presidente.

Após o impeachment, o novo governo (Itamar Franco) reviu as estratégias e prioridades do plano, produzindo uma nova revisão para o período de 1994 a 1995. Enviada ao Congresso Nacional em 1993, a proposta não chegou a ser votada. Segundo Giacomoni (1996), afetado pelos desdobramentos institucionais que decorreram do impeachment, pelos planos de estabilização e pelas duas revisões, esse primeiro esforço de planejamento orçamentário de longo prazo não pode, e não deve, merecer uma avaliação rigorosa quanto aos seus resultados.

Como a nova revisão do PPA não foi votada, mudanças tópicas do plano foram sendo feitas, até o término de sua vigência, para adaptá-lo às medidas que prepararam o lançamento do Plano Real: cortes orçamentários, criação do IPMF, do Fundo Social de Emergência, entre outros.

A ineficácia do primeiro PPA, foi evidenciada pelo relatório Retrato do Desperdício no Brasil, da Comissão Temporária de Obras Inacabadas, do Senado Federal. A partir da

"constatação da existência de milhares de obras que foram iniciadas, absorveram grande soma de recursos e não estão cumprindo a sua finalidade, a comissão cadastrou 2214 obras, onde foram aplicados mais de $\mathrm{R} \$ 15$ bilhões. $\mathrm{O}$ inventário não é completo, por insuficiência de informações e falta de controle, e inclui somente obras cujo financiamento consta dos Orçamentos Fiscal e da Seguridade, deixando de fora obras a cargo das empresas estatais, a despeito das vultosas somas nelas despendidas, como, por exemplo, nas Usinas Nucleares" (Brasil, 1995b, p.7 e p.14).

Utilizando dados constantes do Retrato do Desperdício no Brasil, Garcia (2000), elaborou a tabela 6. Segundo o autor, cerca de $10 \%$ das obras não possuíam datas de início e de paralisação, motivo pelo qual não foram incluídas. A tabela procura destacar o período coberto pelo primeiro 
PPA e as informações são referentes a investimentos (obras) que, por exigência constitucional, devem necessariamente constar do PPA, o que constitui um indicador da qualidade da programação e da competência da gestão.

Tabela 6. Obras inacabadas.

\begin{tabular}{lcc}
\hline \multicolumn{1}{c}{ Período } & № & $(\%)$ \\
\hline Iniciadas e paralisadas antes de 1990 & 107 & 5.4 \\
Iniciadas antes de 1990 e paralisadas até & 222 & 11.3 \\
nov./1995 & & \\
Iniciadas e paralisadas entre 1990 e nov./1995 & 1643 & 83.3 \\
Total & 1972 & 100 \\
\hline
\end{tabular}

Fonte: Brasil (1995b)

Elaborado por Garcia (2000)

Constata-se, desta forma, que quase a totalidade $(94,6 \%)$ dos investimentos foi paralisada durante o período do plano. Os recursos totais para a conclusão das obras é estimado, pela comissão do Senado, como no mínimo igual ao aplicado até a data do relatório; cerca de $\mathrm{R} \$ 15$ bilhões (valores de nov./95). Estes dados revelam, de fato, um retrato do desperdício, assim como da ineficácia das práticas de planejamento, programação e gestão utilizadas no primeiro Plano Plurianual.

Este período é marcado mais fortemente pela política de estabilização do Plano Brasil Novo, reforçando a tendência dos anos 80 . No entanto, a partir do governo Collor, pode-se vislumbrar políticas de cunho estruturalista no que se refere à política industrial, embora esta não atue de forma tão explícita quanto a política industrial que prevaleceu durante a década de 70. 
Observa-se que há uma mudança de orientação da mesma, que passa a adotar uma política de liberalização e abertura comercial, como forma de aumentar o grau de competitividade da indústria nacional.

Assim, a política industrial do Brasil Novo, cujas diretrizes foram definidas em linhas gerais na Exposição de Motivos 48, que acompanhou a Medida Provisória 158, é considerada um dos poucos sinais sobre o estilo das políticas estruturais do governo Collor.

Segundo Fritsch (1990), embora apenas uma declaração de intenções, a política industrial indicava um avanço importante na direção da formulação de princípios, objetivos e instrumentos tradicionais da intervenção estatal na estruturação das decisões de investimento industrial no Brasil.

A nova política industrial enfatizava o aumento da taxa de crescimento da produtividade para o alcance dos objetivos estratégicos de aumento do salário real e retomada do crescimento sustentado. Este novo estilo de política industrial voltava-se para o estímulo à competição e à busca da competitividade como objetivo empresarial básico. Os objetivos eram distintos, mas complementares: a política de competição seria viabilizada por meio da liberalização comercial e a política de competitividade pela revisão dos sistemas de incentivo à capacitação tecnológica e investimentos na promoção de indústrias de alta tecnologia.

\subsubsection{O PPA (1996-1999) - Brasil em Ação}

\subsubsection{Introdução}

O plano plurianual proposto pelo presidente Fernando Henrique Cardoso e elaborado durante a gestão de José Serra no Ministério do Planejamento, foi o segundo plano plurianual aprovado desde que este passou a ser exigido pela Constituição. 
Segundo o Ministério do Planejamento, Orçamento e Gestão, o PPA 1996/99 tinha por objetivo remover os principais obstáculos à consolidação do Real, à retomada do crescimento e ao progresso econômico e social da população. Para a realização destes objetivos, o PPA estabeleceu novos princípios de planejamento no Brasil, com a execução pelo Estado de parcerias entre a União, os estados e os municípios e entre o setor público e o setor privado (Brasil, 1995a).

Assim, o PPA não se restringiu a enumerar metas governamentais, mas delimitou todos os investimentos fundamentais à infra-estrutura econômica, adotando as seguintes estratégias para a ação do Estado no período:

- construção de um Estado moderno e eficiente, pela Reforma do Estado;

- redução dos desequilíbrios espaciais e sociais, pela criação de novas oportunidades, redução de custos, aproveitamento das potencialidades econômicas e melhoria da infra-estrutura;

- inserção competitiva e modernização produtiva, pelo aperfeiçoamento das políticas de abertura comercial, desregulamentação, flexibilização das relações trabalhistas, garantia de concorrência e defesa do consumidor.

Com base nessas estratégias de atuação, o governo previa a realização de ações e projetos envolvendo recursos públicos e privados da ordem de $\mathrm{R} \$ 460$ bilhões. Sendo que deste total, 33\% se destinavam à execução de investimentos, enquanto $67 \%$ seriam aplicados em programas da área social.

Os investimentos propostos pelo PPA enfatizaram os setores de energia elétrica, petróleo, telecomunicações, transportes e saneamento básico, além de investimentos na área de educação, principalmente no ensino básico, em programas de alimentação escolar e em medidas de combate à mortalidade infantil. 


\subsubsection{Contexto macroeconômico}

A partir dos anos 90 e, mais especificamente, da implementação do Plano Real, o cenário macroeconômico brasileiro modificou-se. Com um maior controle sobre a inflação, pôde-se novamente esperar por políticas de desenvolvimento econômico, pouco presentes desde o final da década de 70. Segundo o Ministério do Planejamento, as mudanças ocorridas nos anos 90 que permitiram essa nova orientação da política econômica, foram as seguintes:

- acordo da dívida externa;

- abertura comercial, ampliando a concorrência;

- privatizações;

- aumento da eficiência e queda no endividamento do setor privado;

- controle da inflação a partir de 1994.

Estes fatores permitiram, num primeiro momento, uma elevação do nível de atividade econômica, com uma elevação do consumo, principalmente de bens de consumo duráveis. Segundo o Ministério do Planejamento, os objetivos fixados pelo PPA para os anos de sua vigência eram os seguintes:

- metas de equilíbrio fiscal, como parte da política antiinflacionária e do objetivo de resgate da dívida social;

- metas de crescimento, como condição necessária à incorporação de vastos segmentos da população excluídos dos mercados de trabalho formal e de consumo;

- metas externas que levam em conta a necessidade de manter o financiamento da economia em bases sustentáveis e de consolidar a inserção do país na economia mundial.

As metas de equilíbrio fiscal envolviam a manutenção do equilíbrio das contas públicas e a realocação dos gastos do governo, privilegiando as áreas sociais e o investimento público. Com o plano, esperava-se que os 
dois primeiros anos fossem um período de consolidação do ajuste macroeconômico e de implantação das reformas estruturais para a manutenção de estabilidade da moeda e para a retomada do crescimento econômico. Assim, previa-se uma taxa de crescimento do PIB para 1996 e 1997 de $4 \%$ e 4,5\% respectivamente. Para os anos seguintes essa taxa deveria subir para $5 \%$ ao ano.

Projetava-se o seguinte ambiente macroeconômico, a vigorar durante o período de vigência do PPA - 96 (tabela 7):

Tabela 7. Síntese das projeções - PPA-96.

\begin{tabular}{lcccc}
\hline \multicolumn{1}{c}{ Discriminação } & 1996 & 1997 & 1998 & 1999 \\
\hline Taxa de crescimento do PIB & 4,0 & 4,5 & 5,0 & 5,0 \\
NFSP $^{1}$ (\%PIB) & 0,0 & 0,0 & 0,0 & 0,0 \\
Dívida Interna Líquida S. Público (\%PIB) & 15,3 & 13,7 & 12,0 & 11,0 \\
Dívida Externa Líquida S. Público (\%PIB) & 7,2 & 6,1 & 5,2 & 4,8 \\
Dívida Líquida do S. Público (\%PIB) & 22,5 & 19,8 & 17,2 & 15,8 \\
Déficit Conta Corrente (US\$ bilhões) & 15,4 & 16,1 & 17,1 & 18,1 \\
Dívida Externa Líquida (US\$ bilhões) & 135,4 & 145,5 & 155,6 & 168,7 \\
Dívida Externa Líquida/Exportações & 2,9 & 2,8 & 2,7 & 2,6 \\
Dívida Conta Corrente (\%PIB) $_{\text {FBCF }^{2} \text { (\% PIB, preços de 1980) }}^{2,5}$ & 2,4 & 2,4 & 2,3 \\
\hline
\end{tabular}

Fonte: Brasil (1995a)

${ }^{1}$ Necessidade de Financiamento do Setor Público.

${ }^{2}$ Formação Bruta de Capital Fixo.

Associada à estas projeções, esperava-se uma taxa de juros doméstica declinante até 1999, uma taxa de juros externa de 6,4\%, em média, durante 1996/99 e uma emissão monetária média de 0,5\% do PIB. Parte da dívida pública seria abatida com a receita advinda das privatizações. Esta receita era esperada em torno de um total de $R \$ 21,4$ bilhões a preços de 1996. Na projeção do PPA, a privatização, o crescimento 
do PIB e a queda da taxa de juros permitiriam a redução da dívida pública em 9\% entre 1995 e 1999. Esta queda permitiria a diminuição dos encargos da união e, ao mesmo tempo, permitiria o aumento com despesas correntes e de capital. Quanto à Balança Comercial, esperava-se um aumento no nível de exportações da ordem de $8,6 \%$ ao ano, com a recuperação do superávit comercial a partir de 1996.

A taxa de investimento da economia passaria de $18,5 \%$ do PIB para $20,5 \%$ em 1999, mas continuaria inferior à taxa histórica, registrada no período de 1971/80. Contudo, haveria uma mudança na composição do investimento, com redução na construção civil e aumento da participação de bens de capital, inclusive importados. O investimento público deveria chegar 4\% do PIB em 1999. O financiamento para o investimento bruto total da economia, no período de 1996 a 1999, proviria das seguintes fontes, conforme a tabela 8.

Tabela 8. Fontes de financiamento do investimento.

\begin{tabular}{lc}
\hline \multicolumn{1}{c}{ Discriminação } & Valor (R\$ bilhões) \\
\hline Recursos Nacionais & 836 \\
Orçamentos (governo) (1) & 136 \\
Recursos privados (2) & 700 \\
$\quad$ Expansão dos fundos de pensão & 46 \\
Outros recursos privados & 654 \\
Recursos Externos & 64 \\
Investimentos diretos líquidos & 21 \\
Outros financiamentos líquidos & 43 \\
Total & 900 \\
\hline
\end{tabular}

Fonte: Brasil (1995a)

(1) Inclui o Governo Federal e os Governos Estaduais e Municipais. Exclui as empresas estatais;

(2) Inclui as empresas estatais;

Valores acumulado de 1996/99 a preços de 1996. 
Assim, a maior parte do financiamento do investimento da economia brasileira seria proveniente do setor privado, em função do controle das contas públicas, do processo de desestatização e das perspectivas de ampliação da poupança privada.

Considerando a expansão da economia a partir de 1995 e a queda da taxa de crescimento da população, esperava-se um aumento da renda per capita $16 \%$ superior à renda per capita de 1980 , para o último ano de vigência do PPA. Para o período de 1996/99, a média esperada era de 3,3\%, maior do que a média histórica $(3,2)$, conforme a tabela 9 :

Tabela 9. Taxas médias de crescimento (\%a.a.).

\begin{tabular}{cccc}
\hline Período & PIB & População & Renda per capita \\
\hline $1979-1984$ & 2,3 & 2,3 & 0,0 \\
$1895-1989$ & 4,3 & 1,9 & 2,4 \\
$1990-1994$ & 0,9 & 1,5 & $-0,6$ \\
$1995-1998$ & 4,6 & 1,4 & 3,2 \\
$1996-1999$ & 4,6 & 1,3 & 3,3 \\
\hline
\end{tabular}

Fonte: Brasil (1995a)

\subsubsection{Investimentos e ação governamental}

Neste tópico são apresentados os principais projetos e ações que seriam implementados pelo governo e/ou por ele apoiados no período de vigência do PPA. Os principais investimentos referem-se ao aumento da competitividade da economia e à redução das desigualdades sociais e espaciais.

As tabelas 10 e 11 mostram os valores estimados para os investimentos e o custeio dos projetos e ações, segundo áreas de aplicação, bem como as fontes de financiamento dos projetos. 
Tabela 10. Investimentos e custeio ${ }^{(1)}$.

\begin{tabular}{|c|c|c|c|}
\hline Discriminação & Investimentos $^{(2)}$ & Custeio $^{(3)}$ & Total $^{(4)}$ \\
\hline Infra-estrutura econômica & 85.389 & 332 & 85.721 \\
\hline Transporte & 13.347 & 72 & 13.419 \\
\hline Energia & 38.299 & 260 & 38.559 \\
\hline Comunicações & 33.743 & 0 & 33.743 \\
\hline Recursos hídricos & 6.742 & 920 & 7.662 \\
\hline Gerenciamento r.h. & 60 & 124 & 184 \\
\hline Irrigação & 3.165 & 703 & 3.868 \\
\hline Infra-estrutura & 3.517 & 93 & 3.610 \\
\hline Agricultura & 7.289 & 15.627 & 22.916 \\
\hline Indústria e com. Exterior & 3.735 & 2.971 & 6.706 \\
\hline Turismo & 1.091 & 333 & 1.424 \\
\hline Ciência e tecnologia & 9.430 & 4.925 & 14.355 \\
\hline Meio ambiente & 1.735 & 774 & 2.509 \\
\hline Desenvolvimento social & 29.838 & 270.800 & 300.638 \\
\hline Previdência & 12 & 184.767 & 184.779 \\
\hline Assistência social & 0 & 9.513 & $9.5 \mathrm{I} 3$ \\
\hline Saúde & 4.737 & 40.924 & 45.661 \\
\hline Educação & 4.988 & 6.921 & 11.909 \\
\hline Saneamento & 9.594 & 431 & 10.025 \\
\hline Habitação & 8.072 & 39 & 8.111 \\
\hline Desenvolvimento urbano & 2.277 & 68 & 2.345 \\
\hline Trabalho & 158 & 28.137 & 28.295 \\
\hline $\begin{array}{l}\text { Cultura, desporto, justiça, } \\
\text { segurança e cidadania }\end{array}$ & 1.831 & 2.016 & 3.847 \\
\hline Estado e administração pública & 658 & 1.958 & 2.616 \\
\hline Defesa nacional & 5.652 & 4.917 & 10.569 \\
\hline Total & 153.390 & 305.573 & 458.963 \\
\hline
\end{tabular}

Fonte: Brasil (1995a)

(1)recursos fiscais e da seguridade, financiamentos externos e internos para a União, recursos diretamente arrecadados e FGTS, recursos privados e de Estados e Municípios;

(2)valores médios de 1996;

(3)exceto despesas de pessoal e encargos sociais e custeio administrativo;

(4) valores em $R \$$ (milhões). 
Tabela 11. Fontes de Financiamento (R\$ Milhões) ${ }^{(1)}$.

\begin{tabular}{|c|c|c|c|c|c|c|}
\hline \multirow[t]{2}{*}{ Discriminação } & \multirow[t]{2}{*}{ Total } & \multirow{2}{*}{$\begin{array}{c}\text { Fiscal e } \\
\text { Seguridade }\end{array}$} & \multicolumn{4}{|c|}{ Fontes de Financiamento } \\
\hline & & & Externo & Privado & $\begin{array}{l}\text { Estados } \\
\text { /mun }\end{array}$ & $\begin{array}{c}\text { Outros } \\
\text { (2) }\end{array}$ \\
\hline Infra-estrutura & 85.721 & 5.773 & 10.859 & 30.089 & 5.209 & 33.791 \\
\hline Recursos Hídricos & 7.662 & 2.112 & 2.450 & 1.675 & 1.421 & 4 \\
\hline Agricultura & 22.916 & 7.765 & 1.190 & 0 & 1.260 & 12.701 \\
\hline $\begin{array}{l}\text { Ind. \& com. } \\
\text { Exterior }\end{array}$ & 6.706 & 2.933 & 486 & 1.823 & 0 & 1.464 \\
\hline Turismo & 1.424 & 240 & 640 & 5 & 463 & 76 \\
\hline $\begin{array}{l}\text { Ciência } \\
\text { tecnologia }\end{array}$ & 14.355 & 5.503 & 724 & 5.634 & 872 & 1.892 \\
\hline Meio ambiente & 2.509 & 455 & 1.600 & 72 & 99 & 283 \\
\hline Desenv. Social & 300.638 & 281.018 & 3.334 & 0 & 7.519 & 8.767 \\
\hline $\begin{array}{l}\text { Cultura, desporto, } \\
\text { justiça, segurança } \\
\text { e cidadania }\end{array}$ & 3.847 & 2.532 & 719 & 313 & 272 & 11 \\
\hline Estado e adm. & 2.616 & 1.853 & 233 & 1 & 0 & 529 \\
\hline Defesa Nacional & 10.569 & 8.197 & 2.102 & 0 & 183 & 87 \\
\hline Total & 458.963 & 318.381 & 24.337 & 39.342 & 17.298 & 59.605 \\
\hline
\end{tabular}

Fonte: Brasil (1995a)

(1) Valores Médios de 1996;

(2) Inclui autofinanciamento das empresas estatais, operações oficiais de crédito, financiamentos internos, FGTS etc.

O conjunto de projetos e ações considerados no PPA-96 deveria envolver recursos públicos e privados próximos a $\mathrm{R} \$ 459$ bilhões no período 1996/99, significando um valor médio anual de R\$115 bilhões. Parte desses recursos ( $R \$ 153$ bilhões) estaria destinada à realização de investimentos e R\$ 306 bilhões seria aplicado em despesas com programas de ação área 
social, sendo que $R \$ 185$ bilhões seriam destinados ao pagamento de benefícios da Previdência Social.

De acordo com a tabela 11, do total dos gastos com projetos e ações, aproximadamente 70\%, equivalentes a R\$318 bilhões, seriam financiados com recursos fiscais e da seguridade social da União, destinados, principalmente, a projetos e ações para redução dos desequilíbrios sociais. Excluindo-se os valores relativos ao pagamento de benefícios previdenciários, o PPA buscava levantar recursos da ordem de R $\$$ 274 bilhões, sendo quase $44 \%$ deste total para a área social.

O Governo contava com a participação do setor privado e das outras esferas de governo para viabilizar estes investimentos e ações do PPA. No caso da infra-estrutura, por exemplo, o setor privado poderia participar em média com um terço dos investimentos previstos. Isto mostra uma mudança em relação ao padrão de financiamento do período anterior, caracterizado pela quase totalidade dos investimentos públicos. Já a contribuição dos Estados e Municípios, segundo o esquema de financiamento previsto, deveria alcançar um volume de recursos da ordem de $\mathrm{R} \$ 17,3$ bilhões.

Dentre as fontes de financiamento do plano destacam-se, ainda, os recursos externos ( $R \$ 24,3$ bilhões) e de outras fontes ( $R \$ 59,6$ bilhões), onde predominava o autofinanciamento das empresas estatais, operações oficiais de crédito e recursos oriundos de fundos como o FGTS.

A programação dos projetos e ações prioritárias, em particular na área de infra-estrutura, também dependeria da implantação de novos modelos de gestão e financiamento, que incorporassem maior descentralização de atribuições para outros níveis de governo e a intensificação das parcerias com a iniciativa privada. 


\subsubsection{Investimentos em setores prioritários}

Dentro do conjunto de projetos e ações previstos no PPA, alguns foram classificados como prioritários em vista de seus efeitos dinamizadores e estruturadores de outros projetos e ações dos setores público e privado. Entre estes setores estão incluídas áreas de energia, comunicações, ciência e tecnologia, educação, agricultura e transportes. Segundo o Ministério do Planejamento, o principal critério para sua seleção foi a magnitude do impacto nos chamados fatores sistêmicos ou estruturais de competitividade, com importância na redução do "Custo Brasil". A escolha de setores prioritários do PPA-96 assemelha-se à determinação de metas prioritárias do Plano de Metas (observe o tópico 2.3.2).

\section{Setor energético}

O setor energético, que se desenvolveu baseado nos investimentos estatais, já apresentava à época da formulação do PPA-96 sinais claros de esgotamento.

Embora a necessidade mínima de investimentos fosse de $\mathrm{R} \$ 6$ bilhões anuais, o setor elétrico só conseguia investir $\mathrm{R} \$ 4,5$ bilhões. Esta diferença provocou o atraso na execução dos projetos, cuja conseqüência teria sido pior se a economia brasileira não tivesse enfrentado um prolongado período de estagnação. Da mesma forma, os investimentos realizados no setor petrolífero ao longo dos últimos anos têm estado abaixo do mínimo necessário para o aproveitamento das potencialidades do país.

Assim, o governo propunha para o setor elétrico, a mudança de um modelo centralizado, com forte presença de empresas estatais, para formas mais descentralizadas e abertas à participação da iniciativa privada.

No setor petrolífero, mediante a abertura à área privada, deveria ser eliminado o estrangulamento de recursos para investimentos e redefinido o papel da PETROBRÁs num ambiente mais competitivo, viabilizando a 
ampliação da oferta de petróleo e gás natural. A produção interna de petróleo e gás natural deveria atingir, em 1999, 1,4 milhão de barris/dia e 42,9 milhões de $\mathrm{m} 3 / \mathrm{dia}$, respectivamente. A capacidade de refino deveria alcançar naquele ano mais de 2,0 milhões de barris/dia. Outra proposta para o setor foi a de aumentar as reservas e a produção de petróleo e gás no exterior através da BRASPETRO até atingir 84,1 mil barris/dia em 1999.

\section{Telecomunicações}

$\mathrm{Na}$ área de telecomunicações a recuperação do atraso relativo do país exigiria investimentos da ordem de $\mathrm{R} \$ 31$ bilhões no período 1996/1999, ou seja, uma média anual mais de duas vezes superior à que foi observada no país ao longo dos anos anteriores.

O esforço de investimento projetado pelo Governo objetivava dobrar a rede de telecomunicações, elevando o número de terminais telefônicos instalados de 14,2 milhões para mais de 33 milhões no final da década. 0 plano previa a ampliação dos sistemas de telefonia móvel, rural e urbana, e a diversificação das alternativas de telecomunicações. Objetivava também avançar na modernização tecnológica e na difusão dos serviços essenciais para a reestruturação competitiva da economia na área de transmissão de dados, som e imagem em alta velocidade. Por exemplo, com relação à telefonia fixa, o objetivo era aumentar em 10,2 milhões de acessos.

\section{Ciência e tecnologia}

Quanto à ciência e tecnologia, os gastos neste setor têm sido historicamente baixos, em torno de $0,7 \%$ do PIB, nível inferior aos dos países desenvolvidos ou de níveis de desenvolvimento semelhantes ao do Brasil. Segundo o Ministério do Planejamento, há também uma concentração da responsabilidade sobre o setor público, que arca com $90 \%$ do total investido no país nas atividades de Pesquisa e Desenvolvimento. 
Com o plano, pretendia-se elevar os gastos nacionais em C\&T para o patamar de $1,5 \%$ do PIB, com uma participação do setor privado de $30 \%$ a 40\%. Para o período 1996 a 1999, o PPA propôs investimentos e dispêndios da ordem de $R \$ 14,4$ bilhões, sendo que $R \$ 5,5$ bilhões seriam financiados com recursos fiscais, e o restante com financiamentos externos e internos, recursos de Estados e Municípios e do setor privado. Os dispêndios do Governo Federal visavam prioritariamente estimular a capacidade de inovação do setor produtivo, em particular nas áreas de informação e automação, e o desenvolvimento de tecnologias em áreas como: aeroespacial, nuclear, meio ambiente, recursos do mar e saúde.

\section{Setor educacional}

O governo federal propôs para o período 1996/99 uma aplicação de recursos da ordem de $\mathrm{R} \$ 12$ bilhões no setor educacional. As ações seriam voltadas para o apoio ao desenvolvimento da educação, com prioridade para o ensino básico, mediante: valorização da escola e sua autonomia, com um maior envolvimento da comunidade; programas de valorização do magistério (planos de carreira nos Estados e Municípios); cursos de reciclagem e atualização; descentralização da alimentação escolar; programa de educação à distância; atualização e formação de docentes do ensino fundamental e alfabetização de jovens e adultos; capacitação profissional e aparelhamento das salas de aula, com a introdução de recursos de informática.

O Governo propunha a utilização de recursos do FNDE para serem aplicados no ensino fundamental, estabelecendo critérios de distribuição, compatíveis com a necessidade de recuperar e expandir a rede educacional nas regiões mais carentes. 


\section{Setor agrícola}

Quanto ao setor agrícola o documento reconhece a sua importância: "a agricultura brasileira tem cumprido importante papel no atendimento ao mercado interno, na estabilização de preços e na geração de emprego e divisas, apoiada, sobretudo, em ganhos de produtividade" (Brasil, 1995a). Porém, ainda persistem neste setor desequilíbrios espaciais e sociais que precisam ser superados.

Assim, o governo propôs ações simultâneas em irrigação, ampliação e modernização do transporte intermodal, pesquisa, difusão de informações e promoção da extensão rural, educação e profissionalização dos produtores e trabalhadores rurais, conservação ambiental e defesa agropecuária. O atendimento ao mercado interno e a conquista de novas fatias do mercado agrícola internacional também eram objetivos atrelados ao estímulo à agroindustrialização, à melhoria da infra-estrutura de transportes e à redução da carga tributária incidente sobre o setor.

Para atingir tais objetivos, o papel fundamental do Governo seria definir mecanismos diferenciados de crédito para segmentos descapitalizados do meio rural. Procurou-se também aperfeiçoar a Política de Garantia de Preços Mínimos e o sistema de gestão de estoques públicos, adaptando-os à crescente internacionalização dos mercados. O Programa de Garantia da Atividade Agropecuária (PROAGRO) tinha por objetivo dar sustentação financeira e estimular a modernização tecnológica do setor.

A política social do Governo voltada ao meio rural enfatizava a implantação de projetos de assentamento em parceria com os governos estaduais e municipais e com entidades representativas dos beneficiários, tendo como propósito assentar 280 mil famílias e reduzir o custo médio de cada assentamento. 


\section{Redução dos desequilíbrios espaciais}

Outro grupo de projetos importantes diz respeito à redução dos desequilíbrios espaciais. São projetos na área dos transportes, relacionados à maior integração das regiões brasileiras e à abertura de novas fronteiras de desenvolvimento. Faziam parte dos investimentos para a redução dos desequilíbrios regionais e fortalecimento dos meios de transporte os seguintes programas:

- Eixo de Integração Norte-Sul;

- Eixo de Integração Oeste;

- Eixo de Integração Nordeste;

- Eixo de Integração Sudeste;

- Eixo de integração Sul;

- Saída para o Caribe;

- Saída para o Pacífico;

- Recursos hídricos no Nordeste;

- Ações federais no Rio de Janeiro;

- Infra-Estrutura para o Turismo.

\section{Desenvolvimento social}

O plano continha também projetos que incluíam a geração de empregos, renda e qualificação para o trabalho, por meio das seguintes medidas:

- restabelecimento de linhas de crédito para programas de habitação e saneamento utilizando recursos do FGTS e empréstimos externos;

- apoio a micro e pequenos empreendimentos, trabalhadores autônomos e unidades produtivas organizadas em cooperativas e associações, através de linhas de créditos associadas a 
programas de capacitação técnico-gerencial e fortalecimento da agricultura familiar;

- implantação de um sistema de qualificação profissional, integração das ações do setor público nas áreas de trabalho e educação e articulação com as instituições privadas de formação profissional;

- atendimento ao trabalhador em situação de desemprego, associando os serviços de intermediação da mão-de-obra e de capacitação profissional à concessão do seguro-desemprego; e

- implantação e consolidação de projetos de assentamento rural.

$\mathrm{Na}$ área de assistência social propunha-se:

- aperfeiçoamento dos instrumentos e das entidades envolvidas, visando a garantia dos direitos das crianças, adolescentes e dos portadores de deficiência e, ainda, a municipalização e implementação de associações civis de defesa do consumidor;

- pagamento de benefícios de prestação continuada a idosos e portadores de deficiência;

- aprofundamento do processo de descentralização dos serviços de saúde, criação de maior capacidade gerencial do setor, realização de investimentos para recuperação da capacidade instalada;

- modernização da gestão previdenciária e reforma do sistema de previdência social, visando torná-lo mais viável financeiramente;

- combate à mortalidade na infância, através de um conjunto de programas de assistência integral à saúde da mulher e ao recémnascido, saneamento básico, suplementação alimentar e informação sobre reidratação oral, além do aumento do número de agentes comunitários.

Neste sentido, foi também parte importante da estratégia de atuação do governo na área social o Programa Comunidade Solidária. O programa constituiria uma nova forma de conduzir a atuação do Governo Federal com vistas ao combate à pobreza. 


\subsubsection{PPA-96 - Avaliação}

Com a administração de Itamar Franco, foi recriada a Secretaria do Planejamento e Coordenação da Presidência da República (SEPLAN/PR). A reforma administrativa que inaugura a gestão 1995/1998 transforma a SEPLAN em Ministério do Planejamento e Orçamento, na mesma linha hierárquica dos demais.

Contudo, para Garcia (2000), este fato evidenciou o forte viés econômico/fiscalista por destacar o orçamento como se não fosse parte integrante do planejamento. Esse último foi reduzido à condição de, prioritariamente, cuidar para que a execução orçamentária não comprometesse as metas fiscais necessárias à consolidação do Real. Algo necessário, mas que não esgotaria as possibilidades contidas no planejamento público.

Assim, apesar de o PPA 1996/99 ter sido introduzido por um discurso mais ambicioso, não conseguiu ultrapassar a natureza de um OPI, alcançando apenas o caráter de um plano econômico normativo de médio prazo.

Segundo Garcia (2000), o capítulo que deveria mostrar o cenário futuro do plano intitula-se Cenário Macroeconômico e, como tal, trabalha apenas com variáveis econômicas, como se elas fossem decisivas para promover reformas constitucionais e "construir um Estado moderno e eficiente". O resultado de tais restrições pode ser vislumbrado ao se comparar as projeções desejadas pelo PPA para 1999 com os dados efetivos. 
Tabela 12. 1999_Cenário único e estimativas recentes.

\begin{tabular}{lcc}
\hline \multicolumn{1}{c}{ Variáveis Selecionadas } & $\begin{array}{c}\text { Cenário PPA- } 96 \\
\mathrm{p} / 1999\end{array}$ & $\begin{array}{c}1999 \\
\text { (em estimativas } \\
\text { recentes) }\end{array}$ \\
\hline Crescimento do PIB (\%) & 5,0 & 0,54 \\
Neces. Financ. Do Setor Público & Zero & 15,5 \\
Dívida Pública (\%PIB) & 15,8 & 51,0 \\
Déficit Conta Corrente (US\$ bilhões & & \\
correntes) & US $\$ 18,1$ & US $\$ 25$ a US $\$ 27$ \\
Crescimento das Exportações (\%) & 8,6 a.a. & $-6 \%$ \\
Taxa de Investimento* & 20,5 & 16,25 \\
Renda per capita & $\mathrm{R} \$ 6.195,0$ & $\mathrm{R} \$ 5.317,0$ \\
\hline
\end{tabular}

Fonte: Garcia (2000)

Taxa de Investimento* - Formação Bruta de Capital Fixo/PIB.

O cenário macroeconômico projetado pelo PPA-96 mostrou-se bastante distante daquele apresentado pela economia brasileira em 1999. A taxa de crescimento do PIB foi muito baixa, não atingindo os $5 \%$ esperados. A previsão de redução nas taxas de juros também não se confirmou, afetando os resultados do setor público e dos investimentos. A dívida pública ao invés de diminuir, elevou-se, e a taxa de investimento se manteve bem abaixo da proposta (em torno de $16,2 \%$ do PIB).

As diferenças encontradas na tabela 12 evidenciam a necessidade de se considerar cenários alternativos para ajustes nas ações previstas no plano, de forma a mantê-lo vigente diante das transformações da realidade, que não são previsíveis, mas que sempre acontecem. 
Com relação aos setores considerados prioritários, alguns dos resultados dos programas, em termos de grau de execução física e financeira, estão resumidos na tabela 13 :

Tabela 13. Setores prioritários - alguns resultados.

\begin{tabular}{|c|c|c|c|}
\hline Setor & Proposta p/ 1999 & $\begin{array}{l}\text { Executado em } \\
1999\end{array}$ & $\begin{array}{l}\text { Grau de } \\
\text { Execução }\end{array}$ \\
\hline Energético & $\begin{array}{l}\text { Atingir a produção de } \\
\text { petróleo de } 84,1 \mathrm{Mil} \\
\text { Barris/dia através da } \\
\text { BRASPETRO. }\end{array}$ & $\begin{array}{c}\text { Produção de } \\
74.688,00\end{array}$ & $89 \%$ \\
\hline Telecomunicações & $\begin{array}{c}\text { Ampliar a telefonia fixa } \\
\text { em 10,2 milhões de } \\
\text { acessos. }\end{array}$ & $\begin{array}{l}\text { Ampliado em } \\
2.083 .979,0\end{array}$ & $20 \%$ \\
\hline Ciência e Tecnologia & $\begin{array}{c}\text { Investimentos e } \\
\text { Dispêndios totais de } \mathrm{R} \$ \\
14,4 \text { bilhões }\end{array}$ & $\begin{array}{c}\text { Total de } \\
4.186 .679 .014\end{array}$ & $29 \%$ \\
\hline Educação & $\begin{array}{c}\text { Aplicação de recursos } \\
\text { de } R \$ 12 \text { bilhões }\end{array}$ & $\begin{array}{c}\text { Total de } \\
11.663 .854 .508\end{array}$ & $96 \%$ \\
\hline Agricultura & $\begin{array}{l}\text { Assentamento de } 280 \\
\text { mil famílias }\end{array}$ & $\begin{array}{c}85.226 \text { famílias } \\
\text { assentadas }\end{array}$ & $30 \%$ \\
\hline
\end{tabular}

Fonte: Brasil (2002)

O segundo PPA foi elaborado tendo como referência básica o programa de campanha do presidente FHC. Contudo, sua elaboração não deixa claro as intenções do novo governo devido aos trabalhos de preparação do plano terem sido relegados aos escalões técnicos com baixo envolvimento dos dirigentes políticos. 
Para Garcia (2000), o reducionismo conceitual e o distanciamento dos altos dirigentes fez do segundo PPA um documento apenas formal, um simples cumprimento de obrigações constitucionais.

"De novo, o plano não seria um guia para a ação, mas apenas um OPI expandido, acompanhado de um texto bem elaborado, revelador de uma realidade mais complexa, mas sem articulação consistente com os projetos e ações que, ao final acabam por não acontecer plenamente, mesmo se repensados e redimensionados a cada exercício financeiro" (Garcia, 2000, p.15).

Isto se deve, em grande parte, à inexistência de sistemas de monitoramento e avaliação e à falta de uma prática de planejamento que vá além da elaboração de planos e orçamentos. A ineficácia do PPA para definir prioridades e a intensidade com que deveriam ser implementados projetos e atividades contidos nos orçamentos anuais, pode ser visualizada na tabela 14.

Tabela 14. Execução orçamentário financeira por subprogramas.

\begin{tabular}{|c|c|c|c|c|c|c|c|}
\hline \multirow{3}{*}{$\begin{array}{l}\text { Exercício } \\
\text { Fiscal }\end{array}$} & \multirow{3}{*}{$\begin{array}{l}\text { Número de } \\
\text { Subprogramas }\end{array}$} & \multicolumn{6}{|c|}{ Grau de Execução $^{1}$} \\
\hline & & \multicolumn{2}{|c|}{$\begin{array}{c}\text { Menos de } \\
50 \%\end{array}$} & \multicolumn{2}{|c|}{$\begin{array}{c}\text { Entre } 50 \% \text { e } \\
90 \%\end{array}$} & \multicolumn{2}{|c|}{ Mais de $90 \%$} \\
\hline & & № & $(\%)$ & № & $(\%)$ & $\mathrm{N}^{\mathrm{o}}$ & $(\%)$ \\
\hline 1996 & 152 & 49 & 32.3 & 71 & 46.7 & 32 & 21.1 \\
\hline 1997 & 144 & 38 & 26.4 & 84 & 58.3 & 22 & 15.3 \\
\hline 1998 & 142 & 20 & 14.1 & 87 & 61.3 & 35 & 24.6 \\
\hline
\end{tabular}

Fonte: Garcia (2000)

1 Relação entre Empenho Líquido e Despesa Autorizada (dotação inicial mais créditos adicionais e remanejamentos). 
Os resultados alcançados pelo PPA devem ser avaliados considerando-se o contexto da época, marcado por forte contenção de despesas, decorrentes da busca do ajuste fiscal, conduzindo a dotações orçamentárias globais cadentes em termos reais, à exceção do exercício de 1997, no qual houve um pequeno incremento com respeito ao ano anterior.

Assim, em média, apenas 20\% dos programas atingem mais de $90 \%$ de execução financeira. Além disto, nos três primeiros anos do plano, a média da execução global dos orçamentos anuais foi de 84,8\% (82,2\% em 1996; 81,7\% em 1997; e 90,5 \% em 1998)(Brasil, 1999b). Estes são resultados muito modestos, que apontam a deficiência dos métodos de planejamento e programação adotados. Em nada esses métodos se distinguiram do padrão histórico de elaboração e execução de outros planos.

Seis meses após o lançamento do PPA, foi implementado o Programa Brasil em Ação que, segundo o governo, visava basicamente melhorar a qualidade da gestão de projetos com a participação do setor público. Garcia (2000) considera como seus pontos fortes a seleção de projetos prioritários; a criação da figura do gerente de projeto e a implantação do Sistema de Informações Gerenciais. Já o principal problema viria da aplicação de um modelo de gestão gerencial à sistemática do trabalho do governo .

A criação do Brasil em Ação foi considerada um passo importante para a redução do caráter formal, normativo e pouco dinâmico do planejamento público praticado, pois incorporou elementos para a gestão cotidiana do plano, com a introdução do pensamento estratégico e de alguma visão situacional. 


\subsubsection{O PPA (2000-2003) - Avança Brasil}

\subsubsection{Introdução}

Em outubro de 1998, o governo federal alterou o modelo conceitual e metodológico para a elaboração e gestão do Plano Plurianual (PPA) e dos orçamentos públicos. O projetos de lei do PPA - 2000 e dos orçamentos para o exercício fiscal de 2000 e 2001 foram formulados de acordo com essa nova orientação. Segundo Garcia (2000), as implicações destas mudanças são de diversas ordens e incidem sobre os processos de trabalho, os modelos gerenciais, as estruturas organizacionais, os sistemas de informação e processamento, e os mecanismos de contabilidade e controle da administração pública brasileira.

Assim, o Plano Plurianual de Investimentos para o período de 2000 a 2003 ou Avança Brasil, elaborado pela equipe do Ministério do Planejamento liderada pelo ministro Martus Tavares, foi lançado no dia 31 de agosto de 1999. Atualmente o Plano Plurianual é considerado como o principal instrumento de planejamento de médio prazo das ações do governo brasileiro.

O PPA 2000 constitui um projeto nacional de desenvolvimento que objetiva a mudança na forma de viabilizar os investimentos públicos e prevê parcerias entre o governo federal, estados, municípios, organismos internacionais, organizações não-governamentais e empresas privadas (Brasil, 1999a). Neste segundo PPA do governo de Fernando Henrique Cardoso, foi adotado um novo conceito de programa, segundo o qual as ações e os recursos do governo são organizados de acordo com os objetivos a serem atingidos. O novo PPA trouxe mudanças no sistema de planejamento e orçamento federais que passou a adotar um modelo gerencial voltado para a obtenção de resultados mais concretos, medidos pelos seus efeitos na sociedade. 
O Avança Brasil possui como principais diretrizes a consolidação da estabilidade econômica com crescimento sustentado; a promoção do desenvolvimento, gerando empregos e oportunidades de renda e a redução das desigualdades inter-regionais.

O plano compõe-se de 365 programas desenvolvidos pelo Ministério do Planejamento e pelo BNDES com o objetivo básico de descentralizar o desenvolvimento e a riqueza do país. Os investimentos englobam um total de $\mathrm{R} \$ 317$ bilhões em projetos nas áreas de energia, transportes, telecomunicações, desenvolvimento social, meio ambiente, informação e conhecimento, a serem desenvolvidos por meio de parcerias públicoprivadas.

O Avança Brasil busca reordenar a atuação do governo federal em direção à produção de bens e serviços para a população, proporcionando uma mudança do antigo modelo burocrático para uma nova cultura gerencial. No modelo antigo, os recursos públicos eram direcionados aos órgãos burocráticos, que orientavam a realização da despesa por função de governo: saúde, educação, transportes, cultura e outros.

A partir de $1^{\circ}$ de janeiro de 2000 , os órgãos do governo passaram a atuar de acordo com o modelo gestão empreendedora, na qual os gerentes atuam diretamente no processo, reorganizando as despesas públicas a fim de atingir as metas do PPA.

\subsubsection{Contexto macroeconômico}

O período de referência para a elaboração do PPA 2000-2003 ocorreu em meados de 1999, em meio às incertezas derivadas da mudança no regime cambial ocorrida no início daquele ano. O governo considerava como principais premissas a manutenção da política de austeridade fiscal, a continuidade do regime de flutuação cambial e a consolidação do regime de metas inflacionárias. 
Com base nessa política, projetavam-se taxas de crescimento de $4 \%$ e 4,5\% a.a. para os dois primeiros anos do plano e de $5 \%$ a.a. para os dois anos seguintes. Quanto aos investimentos e às exportações, acreditava-se que a queda nas taxas de juros e a competitividade ampliada para a produção doméstica resultaria em aumento dos investimentos e das exportações e garantiriam a sustentabilidade do processo.

Assim, o principal desafio apontado pelo governo era a necessidade de elevar a poupança doméstica, contando-se para isso, com a conclusão de reformas estruturais, como a tributária, a previdenciária, a da legislação trabalhista e a Lei de Responsabilidade Fiscal.

Quanto aos níveis de emprego e de inflação, o PPA 2000 possui as seguintes metas: reduzir a taxa de desemprego em 1,5 ponto percentual em relação aos níveis observados em meados de 1999, ou seja, para cerca de $6 \%$ da PEA e reduzir as taxas de inflação até atingirem 3\% a.a. em 2003, segundo o IGP-DI.

\subsubsection{Programas e projetos estratégicos}

Segundo o Ministério do Planejamento, Orçamento e Gestão (MPO), um conjunto de 50 programas e projetos estratégicos foi selecionado para dar foco à ação de governo em 2001 e 2002 e garantir a continuidade das transformações sociais e econômicas propostas pelo PPA com vistas ao alcance do desenvolvimento econômico em bases sustentáveis.

Dados do MPO revelam que esse conjunto de empreendimentos deveria envolver, em 2001, a aplicação de recursos no montante de $R \$ 67,2$ bilhões, predominantemente direcionados para a área social, sendo $R \$ 25,1$ bilhões dos Orçamentos Fiscal e da Seguridade Social e R\$42,1 bilhões de outras fontes públicas e privadas. A área social deveria absorver $83 \%$ dos recursos da União direcionados aos programas estratégicos. 
Além destes programas estratégicos, foram desenvolvidos os chamados Planos de Ação Integrada que têm como objetivo solucionar problemas complexos, que exigem uma conjugação de esforços e recursos das três esferas de governo e da sociedade.

A implementação dos programas estratégicos e dos planos de ação integrada deve seguir o novo modelo gerencial do Avança Brasil, visando otimizar resultados com redução de prazos e custos. As tabelas 15 e 16 reúnem estes programas e planos de ação com os recursos que seriam aplicados em 2001.

Tabela 15. Programas estratégicos - PPA-2000.

\begin{tabular}{lc}
\hline \multicolumn{1}{c}{ Programa } & $\begin{array}{c}\text { Recursos em 2001 } \\
\text { (R\$ milhões) }\end{array}$ \\
\hline 01- Toda Criança na Escola & $4.479,3$ \\
02- Escola de Qualidade Para Todos & 68,1 \\
03- Desenvolvimento do Ensino Médio & 567,5 \\
04- Desenvolvimento da Educação Profissional & 689,8 \\
05- Educação de Jovens e Adultos & 303,2 \\
06- Saúde da Família e da Criança & $2.785,2$ \\
07- Valorização do Idoso e da Pessoa Portadora de & $4.416,5$ \\
Deficiência & \\
08- Esporte Solidário & 221,7 \\
09- Erradicação do Trabalho Infantil & 300,7 \\
10- Saneamento Básico & $1.853,3$ \\
11- Saneamento é Vida & 965,5 \\
12- Morar Melhor & 898,0 \\
13- Nosso Bairro & 799,1 \\
14- Carta de Crédito & $4.290,0$ \\
15- Desenvolvimento de Micro, Pequenas e Médias & $11.950,5$ \\
Empresas & \\
16- Qualificação Profissional do Trabalhador & 619,3 \\
17- Agricultura Familiar - PRONAF & $3.861,5$ \\
18- Reforma Agrária & $1.118,3$ \\
19- Energia para as Populações Rurais & $1.046,2$ \\
20- Desenvolvimento da Infra-Estrutura Turística no & 488,2 \\
Nordeste - PRODETUR II & \\
21- Monumenta - Preservação do Patrimônio Histórico & 32,7 \\
22- Segurança e Qualidade de Alimentos & 30,3
\end{tabular}


Tabela 15. Programas estratégicos - PPA-2000.

\begin{tabular}{lc}
\hline \multicolumn{1}{c}{ Programa } & $\begin{array}{c}\text { Recursos em 2001 } \\
\text { (R\$ milhões) }\end{array}$ \\
\hline 23- Segurança Pública & 902,9 \\
24- Transporte Ferroviário Urbano de Passageiros & 480,8 \\
25- Pantanal & 35,8 \\
26- Parques do Brasil & 95,4 \\
27- Prevenção e Combate a Desmatamentos, & 33,4 \\
Queimadas e Incêndios Florestais & \\
28- Sociedade da Informação - Internet II & 152,2 \\
29- Biotecnologia e Recursos Genéticos - Genoma & 82,6 \\
30- Transposição de Águas do São Francisco & 197,7 \\
31- Proágua - Infra-Estrutura & 325,9 \\
32- Irrigação e Drenagem & 210,8 \\
33- Corredor Fronteira Norte & 106,5 \\
34- Corredor Oeste-Norte & 140,0 \\
35- Corredor São Francisco & 23,1 \\
36- Corredor Nordeste & 179,9 \\
37- Corredor Sudoeste & 240,2 \\
38- Corredor Araguaia - Tocantins & 157,2 \\
39- Duplicação da Rodovia Brasília/Itumbiara/Monte & 90,1 \\
Alegre & \\
40- Duplicação da Ferrovia Fernão Dias & 187,8 \\
41- Corredor Transmetropolitano & 212,5 \\
42- Corredor Mercosul & 220,5 \\
43- Manutenção e Restauração de Rodovias & 690,9 \\
44- Aeroportos & 171,2 \\
45- Oferta de Petróleo e Gás Natural & $10.469,0$ \\
46- Gasodutos & 590,6 \\
47- Geração Termelétrica & $5.561,2$ \\
48- Geração Hidrelétrica & $1.891,3$ \\
49- Linhas de Transmissão & 930,4 \\
50- Telecomunidades & $1.025,0$ \\
Total & $67.189,80$ \\
\hline & \\
&
\end{tabular}

Fonte: Brasil (1999a) 
Tabela 16. Planos de ação integrada.

\begin{tabular}{lc}
\hline \multicolumn{1}{c}{ Plano } & Recursos em 2001 \\
& $(\mathrm{R} \$)$ \\
\hline 01- Projeto Alvorada & 5,6 bilhões \\
02- Brasil Empreendedor & 9,2 bilhões \\
03- Plano Nacional de Segurança Pública & 924,3 milhões \\
Total & 15,72 bilhões \\
\hline
\end{tabular}

Fonte: Brasil (1999a)

\subsubsection{O Programa Gestão Pública Empreendedora}

Após a realização de pesquisas nas áreas de planejamento e orçamento do governo federal, as ações do governo foram organizadas em programas, dando uma nova estrutura para o Plano Plurianual, com unidades e gerentes responsáveis; com público alvo e objetivos definidos; indicadores de desempenho de implantação; e metas físicas, orçamentárias e financeiras.

Desta forma, o Programa Gestão Pública Empreendedora (PGPE), que foi concebido pela equipe do Ministério do Planejamento, Orçamento e Gestão sob a responsabilidade da Secretaria de Gestão, representa um esforço para se integrar o planejamento e o orçamento e se atingir a efetiva realização das ações planejadas.

Este programa consiste em um conjunto de ações para o aumento da eficácia das organizações públicas e tem por objetivo transformar a gestão pública, buscando ampliar resultados, reduzir custos e utilizar o conhecimento adquirido e acumulado pelo Brasil, ao longo dos últimos trinta anos (Brasil, 2000).

As ações definidas para o PGPE contam com o apoio do Programa de Modernização da Administração Pública Federal, financiado pelo Banco Interamericano de Desenvolvimento (BID), em andamento desde 1998. Basicamente, o PGPE segue três linhas de projetos: 
- Gestão Empreendedora do Conhecimento. Sua principal atividade é a formulação, em parceria com a Escola Nacional de Administração Pública (ENAP), da política de desenvolvimento gerencial para os gerentes do governo;

- Gestão Empreendedora em Organizações. Este projeto visa a criação de organizações mais flexíveis e autônomas, que trabalhem por resultados e reduzam custos;

- Gestão Empreendedora em Programas. O projeto tem como objetivo o desenvolvimento de programas, com bons sistemas de planejamento, monitoramento e avaliação, para atingir suas metas físicas e financeiras.

\subsubsection{PPA 2000 - Inovações e críticas}

Os dois primeiros PPA's foram elaborados sem o embasamento de uma teoria e uma metodologia próprias de um conceito definidor de plano plurianual ou de uma modalidade de planejamento de médio prazo.

Em 14 de outubro de 1997, procurou-se modificar esta situação com a instituição de um grupo de trabalho integrado por representantes dos Ministérios do Planejamento e Orçamento, da Fazenda, do Tribunal de Contas da União e outras entidades, o GTI (Grupo de Trabalho Interministerial). O GTI tinha a finalidade de elaborar um projeto de lei complementar para dar uma nova formulação ao planejamento.

A demora do governo em modificar a concepção do planejamento pode estar associada à múltiplas causas. $O$ entendimento do planejamento público apenas como planejamento econômico é uma delas e atua mais fortemente quando a economia está dominada pela inflação. "Com a inflação em níveis muito altos torna até surrealista pensar a médio e longo prazos. Todos percebem que a nuvem de poeira quente da inflação não permite enxergar a realidade e muito menos enfrentá-la"1.

${ }^{1}$ Artigo do Ministro do Planejamento para o número zero do informativo VISOR/IPEA, 1999. 
Nos primeiros PPA's não foi concebida a execução do plano e dos orçamentos como instrumentos de gestão estratégica; não foram feitas análises e avaliações das políticas; não se trabalhou com prioridades; e não se buscou a integração e a convergências das ações (Garcia, 2000).

Com a criação do GTI, buscou-se integrar o planejamento com a programação orçamentária, mediante o aperfeiçoamento das definições das principais categorias programáticas dos três instrumentos: O PPA, a LDO e o Orçamento Anual. As principais inovações foram:

- o programa passou a ser unidade básica de organização do PPA e o módulo de integração do plano com o orçamento;

- foram excluídas as categorias subprograma, subprojeto e subatividade;

- os programas passaram a ser referidos, sempre à solução de problemas precisamente identificados, com seus produtos finais necessários estabelecidos, com quantificação de metas e custos;

- os programas passaram a ser integrados por ações.

Pelas propostas do GTI, o planejamento passou a ser visto como um processo permanente, que obedece a princípios técnicos e tem em vista o desenvolvimento econômico e social e a melhoria das condições de vida da população. Assim, o processo de planejamento passa a compreender a elaboração do diagnóstico da situação existente, identificando e selecionando problemas e definindo prioridades.

A mediação entre o PPA e o orçamento passaria a ser feita pela LDO, que estabeleceria prioridades, metas e custos para o exercício subseqüente, entre os programas constantes do PPA.

Em 28 de outubro de 1998, o presidente da República assinou um decreto que criou normas para a elaboração e gestão do Plano Plurianual e dos Orçamentos da União, modificando o sistema de planejamento e orçamentos públicos.

O decreto estabelece que, para a elaboração e execução da PPA e dos Orçamentos, toda a ação finalística do governo será estruturada em 
programas orientados para a consecução dos objetivos estratégicos definidos para o período do Plano. Ação finalística é considerada aquela que proporciona bem ou serviço para atendimento à demanda da sociedade.

Segundo a nova proposta, cada programa deve conter: objetivo, órgão responsável, valor global, prazo de conclusão, fonte de financiamento, indicador que quantifique a situação que o programa queira modificar e metas correspondentes aos bens e serviços necessários para atingir o objetivo. Os programas devem ter ainda metas de qualidade e de produtividade com prazos definidos e devem ser estabelecidos em atos próprios da União, dos estados, do Distrito Federal e dos municípios (com os conceitos definidos em âmbito federal), integrando os PPA's de cada nível de governo. Além disto, todos os programas deverão ter sua execução monitorada e com resultados avaliados e a avaliação de desempenho passará a ser critério para a alocação de recursos orçamentários em anos seguintes.

As novas orientações dão ênfase à gestão e à avaliação e ordenam que cada programa seja dotado de um modelo de gerenciamento, com definição da unidade responsável, com controle de prazos e custos, com sistemas de informações gerenciais e com a designação de um gerente de programa pelo ministro pertinente. A avaliação deve compreender tanto o desempenho físico-financeiro quanto a obtenção de resultados e o grau de satisfação da sociedade em relação aos produtos ofertados.

Com as mudanças buscou-se imprimir ao processo de planejamento e orçamento uma perspectiva mais gerencial. A introdução de elementos que proporcionam o exercício da gestão cotidiana dos programas e de suas ações, a atribuição de responsabilidades, a prática da avaliação e a cobrança de resultados revelam um avanço conceitual e metodológico.

Segundo Garcia (2000), com relação ao PPA 1996-1999, as ações em andamento não tinham sido elaboradas sob o conceito de programa e nem para atacar problemas bem definidos, mas resultaram de uma visão 
convencional, que pouco podia oferecer para a implantação de inovações metodológicas e organizacionais como as pretendidas.

"Aqueles que se dedicaram à elaboração dos programas tiveram enormes dificuldades. Pensar o problema era um tormento, identificar suas causas, um parto a fórceps, construir indicadores uma tortura. O resultado final deixou a desejar. Há grande heterogeneidade, muito reducionismo, elevada setorialização, considerável imprecisão. A orçamentação dos programas foi feita em bases pouco realistas, com muitas metas que não correspondem às capacidades operacionais dos órgãos e às dotações, com muitos custos apurados sem critérios mais rigorosos. Mas, levando-se em conta as condições em que foram elaborados, o pouco tempo disponível e a ausência de informações seguras, os programas do PPA 2000-2003 representam um avanço" (Garcia, 2000, p.37).

Desta forma, ainda que seja impossível elaborar conclusões definitivas, pois a reorganização do planejamento público federal está no início, pode-se afirmar que houve avanços. Embora ainda longe da implantação de um sistema de planejamento pleno, que tenha superado o economicismo, que incorpore o cálculo político e que disponha de direção estratégica, é superior ao que tem sido praticado.

Contudo, sabe-se que construir um sistema de planejamento estratégico público, que seja um poderoso instrumento de governo, requer, antes de mais nada, que se tenha consciência de sua necessidade. Para Garcia (2000), não há indícios seguros de que essa consciência esteja generalizada entre dirigentes públicos, parlamentares, quadros técnicos superiores, universidades e partidos políticos. O tamanho dessa deficiência pode, inclusive, ser tomado como indicador do atraso político institucional do país. 


\subsubsection{Avaliação do cenário macroeconômico e dos programas implementados}

\section{Avaliação do cenário macroeconômico em 2000}

Os resultados para o primeiro ano de execução do PPA, no que se refere ao cenário macroeconômico, mostraram-se relativamente compatíveis com as previsões do plano. Segundo o Ministério do Planejamento, Orçamento e Gestão, o crescimento do PIB de 4,2\% em 2000 foi até superior ao projetado e foi impulsionado pelo aumento do consumo e, em menor medida, do investimento. Da mesma forma, a variação do consumo em 2000, que foi de 5,7\%, superou a estimativa do PPA, que previa um crescimento médio de 4,8\%. Segundo o MPO, este crescimento esteve ligado à melhoria das perspectivas macroeconômicas, associadas ao melhor controle do déficit público e da inflação, e à expansão ao crédito.

Quanto ao investimento, estima-se que este tenha crescido em 2000, mantendo-se próximo a 16\% como proporção do PIB. O desempenho inferior às expectativas pode ser atribuído a níveis ainda elevados de capacidade ociosa em diversos setores, embora em outros, ao longo do ano, tenham se aproximado rapidamente de seus respectivos limites de produção (Brasil, 2001).

Com relação aos setores da economia, no ano 2000 a indústria apresentou uma expansão de $5 \%$ após dois anos de variações negativas. No entanto, a agricultura apresentou uma redução em sua taxa de crescimento, atingindo apenas 3\%, o que pode estar associado à condições climáticas adversas. O crescimento industrial concentrou-se, em sua maior parte, na produção de bens de consumo duráveis, com aumento de $20,5 \%$, e de bens de capital, com aumento de 12,7 \%. Bens intermediários cresceram $7 \%$ e destacou-se também o setor de comunicações com um crescimento de $17 \%$. 
No mercado de trabalho houve uma redução da taxa média de desemprego de $7,6 \%$ para $7,4 \%$ da PEA. Mas a meta do PPA é uma redução do nível de desemprego para 6\% da PEA até 2003.

Em 2000, a variação do IGP-DI, em termos de média anual foi 9,81\%, acima daquela projetada no PPA. Segundo o MPO, este fato deve-se às mudanças de preços relativos após a mudança do regime cambial, que revelaram-se mais profundas que a experiência anterior podia prever, e assim os preços no atacado registraram variações bastante fortes (30\% em 1999 e 20\% em 2000), pressionando os índices gerais de preços.

Quanto ao comércio exterior, o ano 2000 apresentou alguma melhoria, com crescimento das exportações e das importações de $14,7 \%$ e $13,4 \%$ respectivamente, fazendo com que o déficit na Balança Comercial declinasse de US\$1,2 bilhão em 1999 para US\$0,7 bilhão em 2000. O destaque desse setor foi o crescimento de $19 \%$ das exportações de manufaturados, enquanto as exportações de produtos básicos cresceram $8,5 \%$ em volume e $6,2 \%$ em valor. O aumento das importações concentrou-se nos bens intermediários $(16,5 \%)$, refletindo a retomada do crescimento, e também nos combustíveis (60\%) em decorrência da elevação, em 2000, dos preços do petróleo. O déficit em conta corrente declinou para US\$ 24,7 bilhões $(4,2 \%$ do PIB) e os investimentos estrangeiros diretos atingiram US\$ 31 bilhões.

Com relação ao desempenho das contas públicas, observou-se um superávit primário de 3,6\% do PIB em 2000. Mas, considerando-se apenas o Governo Federal, houve uma redução do superávit primário de 2,3\% do PIB para $1,9 \%$.

\section{Avaliação do cenário macroeconômico em 2001}

No ano 2001 os resultados da economia brasileira foram inferiores aos do ano anterior, se distanciando bastante do cenário inicial proposto pelo PPA-2000. A crise energética e as instabilidades no cenário 
internacional como a crise argentina e os ataques terroristas nos EUA atuaram como fatores restritivos, gerando uma redução no ritmo da economia. Além destes fatores, a trajetória ascendente da taxa de juros e a desvalorização cambial dificultaram a efetivação das metas do PPA.

Assim, o crescimento do PIB em 2001 de 1,51\% esteve bem abaixo do projetado pelo PPA (4,5\%). A taxa de inflação também sofreu os impactos negativos dos fatores acima mencionados situando-se em torno de $10,36 \%$ contra $4,3 \%$ previstos no cenário PPA.

Quanto às contas públicas, o governo federal atingiu um superávit primário de $1,86 \%$ do PIB que foi, contudo, abaixo do projetado pelo plano (2,6\% do PIB).

Em 2001, a indústria apresentou flutuações que decorreram das crises externas e de energia e foram responsáveis por grande parte da redução do desempenho do setor. Assim, após ter crescido 5\% em 2000, a produção industrial expandiu-se apenas $1,4 \%$ em 2001. Com relação ao setor agrícola, observa-se um bom desempenho quanto à produção de grãos, superando em $18,4 \%$ a safra de 2000 .

O mercado de trabalho apresentou uma taxa de desemprego aberto total de $6,8 \%$ em janeiro de 2002 . Esta foi reduzida em relação ao ano 2000, mas continua acima das projeções do PPA.

Além dos fatores mencionados, como as crises interna e externa, a política macroeconômica presente no período tem constituído fator de restrição à realização das propostas do plano. A política macroeconômica, no período do PPA-2000/03, está centrada na manutenção da estabilidade econômica. Desta forma, a política fiscal no período é restritiva a fim de atingir superávits primários e estabilizar a dívida líquida do setor público como porcentagem do PIB. O regime de metas inflacionárias e de taxa de câmbio flutuante são os demais componentes da política macroeconômica, que acabaram por influenciar, também a capacidade de gasto do plano (Brasil, 2002). 
Tabela 17. Cenário macroeconômico PPA-2000: projetado e realizado.

\begin{tabular}{ccccc}
\hline Variáveis & \multicolumn{2}{c}{2000} & \multicolumn{2}{c}{2001} \\
\cline { 2 - 5 } Selecionadas & $\begin{array}{c}\text { Projetado } \\
\text { pelo PPA }\end{array}$ & $\begin{array}{c}\text { Dados } \\
\text { Efetivos }\end{array}$ & $\begin{array}{c}\text { Projetado } \\
\text { pelo PPA }\end{array}$ & $\begin{array}{c}\text { Dados } \\
\text { Efetivos }\end{array}$ \\
\hline Crescimento do PIB & 4 & 4,2 & 4,5 & 1,51 \\
Taxa de Inflação $^{1}$ & 6 & 9,81 & 4,3 & 10,4 \\
Superávit Primário & 2,65 & 2,87 & 2,6 & 1,86 \\
Taxa de & 20 & 15,8 & 20 & 16,5 \\
Investimento $^{3}$ & & & & \\
Taxa de & 6 & 7,8 & 6 & 6,8 \\
Desemprego & & & & \\
\hline
\end{tabular}

Fontes: Brasil (2002); IPEA (2002)

${ }^{1}$ Variação do IGP-DI;

${ }^{2}$ Superávit Primário do Governo Central;

${ }^{3}$ FBCF/PIB e ${ }^{4}$ Taxa de Desemprego Aberto.

\section{Avaliação dos programas implementados pelo PPA}

Quanto ao gerenciamento e à execução dos programas do Governo Federal, o Relatório de Avaliação do PPA 2000-2003 apontou as seguintes restrições: descontinuidades no fluxo de recursos; dificuldades de articulação entre órgãos com ações complementares; insuficiência de pessoal qualificado; infra-estrutura inadequada, entre outros. Além destas, outras restrições decorrem do próprio modelo de gestão por programas, introduzido pelo Avança Brasil, como por exemplo, a falta de um entendimento mais claro e normativo sobre o papel do gerente na estrutura administrativa e a inexperiente participação deste nos processos decisórios. 
Tabela 19. Resultados e realização física dos programas do PPA-2000.

\begin{tabular}{|c|c|c|}
\hline Programas & Resultados & Realização Física \\
\hline $\begin{array}{l}\text { Dentro ou acima do } \\
\text { previsto }\end{array}$ & $74,4 \%$ & $69,4 \%$ \\
\hline $\begin{array}{l}\text { Abaixo ou muito abaixo } \\
\text { do previsto }\end{array}$ & $23,3 \%$ & $30,6 \%$ \\
\hline $\begin{array}{ll}\text { Não } & \text { apresentou } \\
\text { resultados } & \end{array}$ & $2 \%$ & - \\
\hline
\end{tabular}

Fonte: Brasil (2002)

A avaliação quanto aos resultados do programa mostrou que $74,4 \%$ dos programas tiveram seus resultados considerados dentro ou acima do previsto, 23, 3\% tiveram resultados abaixo ou muito abaixo do previsto e $2 \%$ dos programas não apresentaram resultados. No entanto, o Relatório salienta que o conceito de resultado ainda é muito difuso na administração pública mas que, em sua maioria, os gerentes consideraram como resultado a melhoria das condições de oferta de bens ou serviços à população beneficiária.

Com relação ao cumprimento de metas físicas dos programas, foi constatado que $14,6 \%$ destes (50 programas) ficaram acima do que foi previsto inicialmente, $54,8 \%$ conseguiram se manter dentro do previsto e $30,6 \%$ dos programas apresentaram cumprimento de metas físicas abaixo do previsto. Os resultados para a execução dos programas nos dois primeiros anos do PPA-2000 apontam para um grau de implementação do plano maior que o do seu antecessor. 


\section{EVOLUÇÃO DE INDICADORES E A ECONOMIA BRASILEIRA}

O estudo do planejamento público federal nas duas últimas décadas deve ser acompanhado de uma análise do panorama econômico brasileiro por meio de indicadores sócio-econômicos. O objetivo desta análise é avaliar se as propostas e as realizações dos planos de desenvolvimento encontramse coerentes com os resultados apresentados pela economia brasileira.

Primeiramente, apresenta-se uma visão macroeconômica dos principais resultados alcançados pelo país nas últimas décadas e, posteriormente, realiza-se uma contextualização de indicadores aos planos de desenvolvimento de cada período. Nesta fase observam-se os seguintes índices: PIB, renda per capita, taxa de investimento agregado, produção setorial, nível de emprego, inflação, dívida externa, dívida interna, carga tributária, salário mínimo, índice de Gini, IDH e índice de pobreza. Estes indicadores foram escolhidos uma vez que a maior parte dos planos analisados contêm propostas que visam modificar seus valores.

Assim, procura-se observar a evolução de indicadores econômicos e sociais, de modo a comparar as oscilações da política de desenvolvimento com os rumos do crescimento econômico do país. 


\subsection{Panorama geral da economia brasileira}

Ao longo das décadas de 50, 60 e 70 o Brasil foi um dos países que mais cresceu no mundo, obtendo altas taxas de crescimento e acompanhando a tendência da economia mundial, uma vez que este período é também chamado de "os trinta anos gloriosos da economia capitalista". Nesta época, a política econômica brasileira tinha como objetivo principal a industrialização e o crescimento econômico, era a fase desenvolvimentista, do Plano de Metas de JK e do I e II PND.

A partir de 1979, os efeitos do segundo choque do petróleo e da elevação das taxas de juros internacionais reduziram as fontes de financiamento do desenvolvimento. O crescimento com endividamento tornou-se insustentável, fato este apontado como fator desacelerador da política desenvolvimentista contida no II e no III PND, que cederam lugar à políticas mais recessivas.

A recessão internacional gerada pelo aumento dos juros e do preço do petróleo, provocou a queda das exportações e a política econômica do presidente Figueiredo gerou uma alteração nos preços relativos, elevação da taxa de juros interna real e desvalorização cambial.

Na segunda metade dos anos 80 e início dos anos 90, os fracassos sucessivos das tentativas de estabilização provocaram o aumento da inflação e a introdução de novas fontes de incerteza (política e inflacionária) na economia brasileira. Esta situação de inflação generalizada e incerteza inflacionária fazia com que os preços relativos perdessem a sua função alocativa. Apenas surtos de crescimento, como o induzido pelo Plano Cruzado em 1986, marcaram a segunda metade dos anos 80 e início dos anos 90. Determinados elementos contidos no Plano Cruzado, como o "gatilho salarial" associado à queda da inflação, induziram um aumento na demanda agregada e a um razoável crescimento dos investimentos e do PIB no ano de 1986. 
A partir da década de 90 e do lançamento do Plano Collor, há uma maior liberalização da economia e um crescimento do acúmulo de reservas internacionais devido à política de taxas internas de juros elevadas. Estas, apesar de desestimularem o investimento interno no período, foram fundamentais para garantir a viabilidade do lançamento, em 1994, do Plano Real.

Assim, apesar da crise política de 1992 e da incerteza associada à taxas de inflação mensais superiores à $40 \%$, a partir de 1994 passou a haver entre os agentes econômicos um maior otimismo quanto à recuperação econômica e política devido ao Plano Real, que gerou uma queda drástica da inflação.

Segundo Baer (1996), o Plano Real possuía como vantagem em relação dos planos de estabilização anteriores, o fato de ter sido precedido por uma tentativa de ajuste fiscal e por não se valer de congelamentos de preços. A conseqüência imediata foi o boom na atividade econômica e a valorização da taxa de câmbio, causando uma vigorosa expansão das importações, o que foi chamado de âncora cambial.

Desta forma, após mais de 13 anos de crescimento modesto, inflação alta e taxa de investimento declinante, a economia brasileira iniciou em 1993/94 uma fase de crescimento e recuperação da taxa de investimento. A taxa de investimento e o PIB voltaram a crescer no biênio 1994/95, porém em níveis relativamente baixos.

O principal motivo apontado para a elevação da taxa de investimento neste período é a redução da inflação e da incerteza inflacionária, possibilitando o crescimento da demanda e uma maior utilização da capacidade instalada. Assim, a taxa de investimento chegou a $16,7 \%$ do PIB em 1995. Além disto, a parcela maior dos gastos com bens de capital foi direcionada para a aquisição de máquinas e equipamentos, principalmente importados, com reflexos positivos sobre a eficiência do investimento. 
Entretanto, a trajetória de crescimento econômico associada à necessidade de equilíbrio externo e de manutenção da estabilidade de preços levou, em 1995, à ajustes na política cambial, comercial e monetária, cujos resultados foram a desaceleração do crescimento e a estagnação na taxa de investimento a partir de 1996.

Em 1999 tem-se uma nova mudança na política cambial decorrente da dificuldade de manutenção da taxa de câmbio num cenário de desconfiança internacional e saída de divisas. Novamente a economia brasileira sofre as conseqüências das crises externas e a taxa de investimento cai de 17,7\% em 1998 para 16,2\% em 2000.

O ano 2000 apresentou um crescimento do PIB de 4,2\% que foi possivelmente impulsionado pelo aumento do consumo e do investimento. No entanto, este ciclo de crescimento foi abalado a partir de 2001 devido à pressões negativas na conjuntura internacional e à crise interna relacionada às restrições de energia elétrica no país.

\subsection{Indicadores e planos de desenvolvimento}

\subsubsection{Indicadores da produção}

\subsubsection{O produto interno bruto e a renda per capita}

O crescimento da produção é um dos objetivos centrais de toda política de desenvolvimento. Assim, a maior parte dos planos de desenvolvimento elaborados no Brasil considerou o crescimento do PIB e da renda per capita como principais metas.

Durante o período de implementação do Plano Salte e do Plano de Metas, observou-se uma preocupação governamental em desenvolver os setores considerados prioritários para o avanço do processo de substituição 
de importações. Procurou-se, desta forma, criar a infra-estrutura necessária ao desenvolvimento industrial. Este fato é bastante explícito durante a implementação do Plano de Metas cujos resultados geraram um crescimento expressivo da produção com elevação anual do PIB e da renda per capita de $8,2 \%$ e $5 \%$ no período.

Já no início dos anos 60, o país enfrenta uma crise econômica com aceleração inflacionária modificando as diretrizes do planejamento econômico. Ainda que persistisse o objetivo de crescimento econômico, o controle inflacionário tornou-se prioritário. Assim, o Plano Trienal e o PAEG continham medidas de combate à inflação como a redução no gasto público e o aumento da carga tributária. Estas medidas, embora tenham gerado uma redução da inflação e melhoria das contas públicas, não conseguiram evitar a desaceleração da taxa de crescimento do PIB. Quanto à renda per capita, observa-se uma queda de 2,3\% em 1963 e um crescimento lento (1,23\% em média) durante o período de implementação do PAEG.

O período posterior é marcado por uma mudança na política econômica que torna-se menos restritiva e modifica o diagnóstico da inflação (de demanda para custos). O planejamento volta-se novamente para o crescimento econômico e, esta mudança associada à condições externas extremamente favoráveis, proporciona um período de elevado crescimento econômico, com taxas médias anuais de $11 \%$ de crescimento do PIB e de $7,8 \%$ da renda per capita. Este crescimento, liderado pelo setor industrial, teve início a partir da implantação do PED e perdurou até o final do I PND.

O II PND manteve o modelo de desenvolvimento apesar de as condições da economia brasileira, assim como as condições internacionais, modificarem-se a partir de 1974 iniciando uma fase de retração. Assim, embora a principal meta do II PND fosse a manutenção de uma taxa de crescimento do PIB em torno de $10 \%$ ao ano, o índice alcançado foi em média de $6,38 \%$. 
Nos planos de desenvolvimento das décadas de 80 (III PND e I PNDNR) evitou-se a quantificação de metas de crescimento da produção e da renda per capita. Apenas o PAG apresentou metas bem definidas para o crescimento do PIB (em média $6 \%$ para o período de sua implementação). No entanto, a variação média do PIB foi de $1,95 \%$, com uma queda anual média da renda per capita de 1,07\%, refletindo a longa fase de estagnação econômica que se inicia nos anos 80 . A recessão e a queda na renda per capita, associada à índices elevados de inflação, levaram a denominação desta fase de a "década perdida". Esta tendência se manteve durante o PPA91, com modificações a partir de 1994 decorrentes do Plano Real. A partir de 1994 houve um período de recuperação da renda per capita que perdurou até 1997, quando novamente esta entrou em declínio como decorrência da desaceleração da economia.

A partir de 1996, os PPA's passaram a explicitar suas metas de crescimento do PIB. Assim, o PPA-96 previa uma taxa média de crescimento do PIB de 4,63\% para o período de 1996 a 1999, mas esta manteve-se em $1,67 \%$.

A política macroeconômica, sobretudo a monetária, restritiva e voltada para a consolidação da estabilidade econômica seria um dos principais fatores responsáveis pela baixa taxa de crescimento do PIB. Segundo Barros \& Goldenstein (1997), a principal crítica feita ao Plano Real é que ele condenaria o Brasil a continuar com baixas taxas de crescimento. Isto porque, segundo essas críticas, a opção por uma âncora cambial teria resultado em uma valorização da taxa de câmbio que incentivaria quedas substanciais de nossas exportações e estimularia as importações.

Desta forma, aumentos nas importações não financiados por exportações, gerariam a necessidade de manter altas taxas de juros como forma de atrair o capital especulativo, contribuindo para a manutenção de baixos patamares de crescimento da produção. De fato, a manutenção de elevadas taxas de juros no país têm constituído um dos principais fatores inibidores do investimento e do crescimento econômico. 
No entanto, Barros \& Goldenstein (1997) argumentam que deve-se levar em consideração o processo de reestruturação da economia brasileira e seus conseqüentes ganhos de produtividade em diversos segmentos. Neste sentido, o crescimento do PIB no ano 2000 de 4,2\%, acima das previsões do PPA-2000, poderia, por sua vez, estar associado à estes ganhos de produtividade, e não apenas à elevação do consumo e do investimento ocorrida neste ano.

Em 2001, o crescimento do PIB foi de apenas 1,51\% afetado pela situação externa adversa, pela crise de energia e pela política macroeconômica restritiva. 


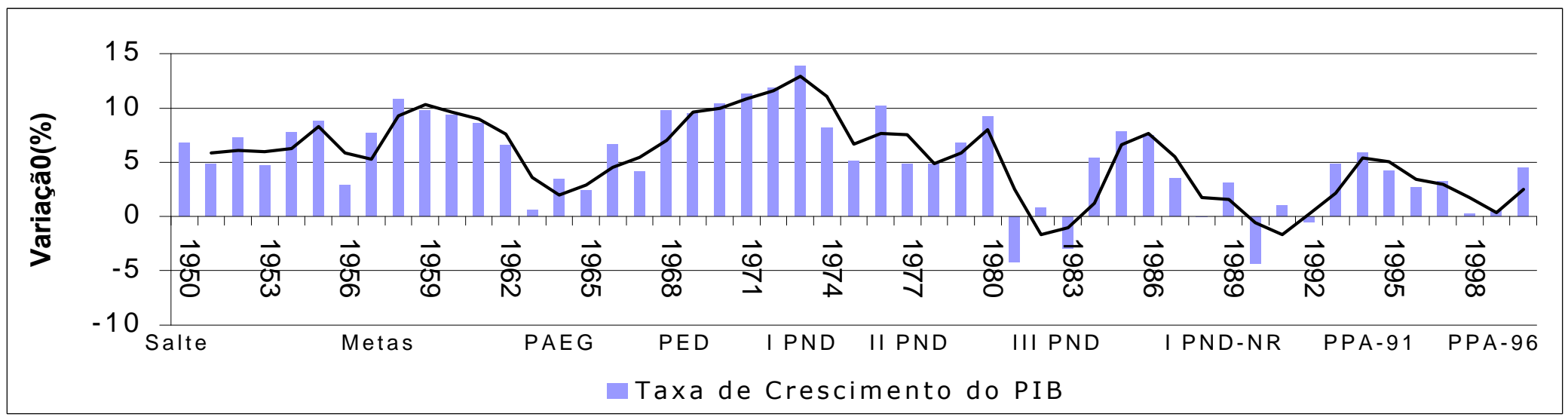

Figura 1 - Taxa de crescimento do PIB $1950-2000$.

Fonte: IPEA (2002)

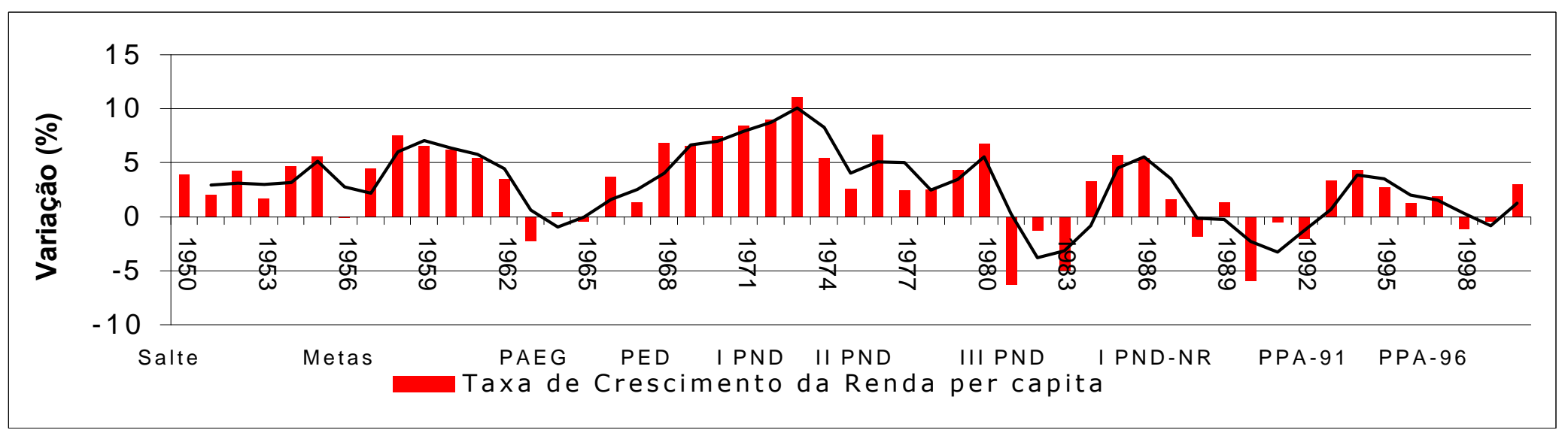

Figura 2 - Taxa de crescimento da renda per capita 1950 - 2000.

Fonte: IPEA (2002) 
Tabela 19. Planos de desenvolvimento e PIB.

\begin{tabular}{|c|c|c|c|c|}
\hline Ano & Plano & $\begin{array}{c}\text { PIB } \\
\text { Preços } 2000 \\
\text { (R\$ Bilhões) }\end{array}$ & $\begin{array}{c}\text { PIB } \\
\text { Taxa de } \\
\text { Crescimento } \\
(\%)\end{array}$ & $\begin{array}{c}\text { Média } \\
(\%)\end{array}$ \\
\hline $\begin{array}{l}1950 \\
1951\end{array}$ & Plano Salte & $\begin{array}{l}84,4 \\
88,6\end{array}$ & $\begin{array}{l}6,8 \\
4,9\end{array}$ & 5,8 \\
\hline $\begin{array}{l}1952 \\
1953 \\
1954 \\
1955\end{array}$ & & $\begin{array}{c}95,0 \\
99,5 \\
107,26 \\
116,70\end{array}$ & $\begin{array}{l}7,3 \\
4,7 \\
7,8 \\
8,8\end{array}$ & \\
\hline $\begin{array}{l}1956 \\
1957 \\
1958 \\
1959 \\
1960 \\
1961\end{array}$ & Plano de Metas & $\begin{array}{l}120,09 \\
129,33 \\
143,30 \\
157,35 \\
172,14 \\
186,94\end{array}$ & $\begin{array}{c}2,9 \\
7,7 \\
10,8 \\
9,8 \\
9,4 \\
8,6\end{array}$ & 8,2 \\
\hline 1962 & & 199,28 & 6,6 & \\
\hline 1963 & Plano Trienal & 200,47 & 0,6 & 0,6 \\
\hline $\begin{array}{l}1964 \\
1965 \\
1966 \\
1967\end{array}$ & PAEG & $\begin{array}{l}207,29 \\
212,26 \\
226,49 \\
236,49\end{array}$ & $\begin{array}{l}3,4 \\
2,4 \\
6,7 \\
4,2\end{array}$ & 4,17 \\
\hline $\begin{array}{l}1968 \\
1969 \\
1970\end{array}$ & PED & $\begin{array}{l}259,13 \\
283,74 \\
310,25\end{array}$ & $\begin{array}{c}9,8 \\
9,5 \\
10,4\end{array}$ & 9,9 \\
\hline $\begin{array}{l}1971 \\
1972 \\
1973 \\
1974\end{array}$ & $\begin{array}{c}\text { Metas e Bases } \\
\text { I PND }\end{array}$ & $\begin{array}{l}348,78 \\
390,43 \\
444,97 \\
481,25\end{array}$ & $\begin{array}{c}11,3 \\
11,9 \\
13,9 \\
8,2\end{array}$ & 11,9 \\
\hline $\begin{array}{l}1975 \\
1976 \\
1977 \\
1978 \\
1979\end{array}$ & II PND & $\begin{array}{l}506,11 \\
558,03 \\
585,56 \\
614,66 \\
656,21\end{array}$ & $\begin{array}{c}5,1 \\
10,2 \\
4,9 \\
4,9 \\
6,8\end{array}$ & 6,38 \\
\hline $\begin{array}{l}1980 \\
1981 \\
1982 \\
1983 \\
1984 \\
1985\end{array}$ & III PND & $\begin{array}{l}716,58 \\
686,13 \\
691,82 \\
671,55 \\
707,82 \\
760,08\end{array}$ & $\begin{array}{c}9,2 \\
-4,2 \\
0,83 \\
-2,93 \\
5,4 \\
7,85\end{array}$ & 2,69 \\
\hline
\end{tabular}


Tabela 19. Planos de desenvolvimento e PIB.

\begin{tabular}{ccccc}
\hline Ano & Plano & $\begin{array}{c}\text { PIB } \\
\text { Preços 2000 } \\
\text { (R\$Bilhões) }\end{array}$ & $\begin{array}{c}\text { PIB } \\
\text { Taxa de } \\
\text { Crescimento } \\
(\%)\end{array}$ & $\begin{array}{c}\text { Média } \\
(\%)\end{array}$ \\
\hline 1986 & & 820,56 & 7,49 & \\
1987 & I PND-NR/PAG & 849,52 & 3,53 & 1,95 \\
1988 & 849,01 & $-0,06$ & \\
1989 & & 875,84 & 3,16 & \\
1990 & & 837,74 & $-4,35$ & \\
1991 & & 846,39 & 1,03 & \\
1992 & & 841,79 & $-0,54$ & \\
1993 & PPA-91 & 883,24 & 4,9 & \\
1994 & & 934,91 & 5,85 & \\
1995 & & 974,36 & 4,22 & \\
1996 & & 1000,28 & 2,66 & \\
1997 & & 1032,99 & 3,27 & \\
1998 & PPA-96 & 1035,26 & 0,22 & \\
1999 & & 1040,85 & 0,54 & \\
2000 & & 1086,51 & 4,45 & \\
2001 & & & 1,51 & \\
\hline
\end{tabular}

Fonte: IPEA (2002)

Tabela 20. Planos de desenvolvimento e renda per capita.

\begin{tabular}{|c|c|c|c|c|}
\hline Ano & Plano & $\begin{array}{c}\text { Renda per capita* } \\
\text { (US } \$ \text { ) }\end{array}$ & Variação (\%) & $\begin{array}{l}\text { Média } \\
(\%)\end{array}$ \\
\hline 1950 & Plano Salte & 887 & 3,89 & 2,93 \\
\hline 1951 & & 904 & 1,98 & \\
\hline 1952 & & 943 & 4,27 & \\
\hline 1953 & & 959 & 1,69 & \\
\hline 1954 & & 1001 & 4,68 & \\
\hline 1955 & & 1060 & 5,62 & \\
\hline 1956 & & 1059 & $-0,12$ & \\
\hline 1957 & & 1107 & 4,53 & \\
\hline 1958 & Plano de Metas & 1190 & 7,53 & \\
\hline 1959 & & 1268 & 6,56 & 5,01 \\
\hline 1960 & & 1347 & 6,18 & \\
\hline 1961 & & 1420 & 5,42 & \\
\hline 1962 & & 1470 & 3,49 & \\
\hline 1963 & Plano Trienal & 1436 & $-2,30$ & $-2,305$ \\
\hline
\end{tabular}


Tabela 20. Planos de desenvolvimento e renda per capita.

\begin{tabular}{|c|c|c|c|c|}
\hline Ano & Plano & $\begin{array}{c}\text { Renda per capita* } \\
\text { (US\$) }\end{array}$ & Variação (\%) & $\begin{array}{c}\text { Média } \\
(\%)\end{array}$ \\
\hline 1964 & \multirow{4}{*}{ PAEG } & 1442 & 0,43 & \multirow{4}{*}{1.23} \\
\hline 1965 & & 1435 & $-0,50$ & \\
\hline 1966 & & 1488 & 3,70 & \\
\hline 1967 & & 1508 & 1,31 & \\
\hline 1968 & \multirow{3}{*}{ PED } & 1610 & 6,79 & \multirow{3}{*}{6,92} \\
\hline 1969 & & 1715 & 6,54 & \\
\hline 1970 & & 1843 & 7,45 & \\
\hline 1971 & \multirow{4}{*}{$\begin{array}{l}\text { Metas e Bases } \\
\text { I PND }\end{array}$} & 1999 & 8,42 & \multirow{4}{*}{8,49} \\
\hline 1972 & & 2179 & 9,04 & \\
\hline 1973 & & 2421 & 11,07 & \\
\hline 1974 & & 2553 & 5,45 & \\
\hline 1975 & \multirow{5}{*}{ II PND } & 2619 & 2,58 & \multirow{5}{*}{3,9} \\
\hline 1976 & & 2818 & 7,60 & \\
\hline 1977 & & 2887 & 2,45 & \\
\hline 1978 & & 2960 & 2,54 & \\
\hline 1979 & & 3088 & 4,31 & \\
\hline 1980 & \multirow{6}{*}{ III PND } & 3297 & 6,77 & \multirow{6}{*}{0,5} \\
\hline 1981 & & 3090 & $-6,29$ & \\
\hline 1982 & & 3049 & $-1,30$ & \\
\hline 1983 & & 2899 & $-4,94$ & \\
\hline 1984 & & 2993 & 3,26 & \\
\hline 1985 & & 3164 & 5,71 & \\
\hline 1986 & \multirow{5}{*}{ I PND-NR/PAG } & 3335 & 5,42 & \multirow{5}{*}{0,12} \\
\hline 1987 & & 3389 & 1,60 & \\
\hline 1988 & & 3326 & $-1,85$ & \\
\hline 1989 & & 3372 & 1,39 & \\
\hline 1990 & & 3172 & $-5,92$ & \\
\hline 1991 & \multirow{5}{*}{ PPA-91 } & 3154 & $-0,56$ & \multirow{5}{*}{1,56} \\
\hline 1992 & & 3088 & $-2,06$ & \\
\hline 1993 & & 3193 & 3,36 & \\
\hline 1994 & & 3331 & 4,32 & \\
\hline 1995 & & 3423 & 2,76 & \\
\hline 1996 & \multirow{4}{*}{ PPA-96 } & 3466 & 1,25 & \multirow{4}{*}{0,07} \\
\hline 1997 & & 3530 & 1,87 & \\
\hline 1998 & & 3488 & $-1,20$ & \\
\hline 1999 & & 3470 & $-0,51$ & \\
\hline 2000 & PPA-2000 & 3574 & 3,00 & 3,00 \\
\hline
\end{tabular}

Fonte: IPEA (2002)

* US\$ (valor real - preços constantes de 2000). 


\subsubsection{A taxa de investimento}

A maior parte dos planos de desenvolvimento elaborados no Brasil continham entre suas metas principais a elevação da taxa de investimento. O objetivo de elevar a taxa deve-se ao reconhecimento de que a formação de capital representa um componente importante para o crescimento econômico de um país. A taxa de investimento é compreendida como a relação formação bruta de capital fixo/produto interno bruto (FBCF/PIB).

Durante os anos 70, houve uma grande preocupação governamental em elevar a taxa de investimento no país, principalmente no setor industrial. A maior parte deste investimento, cerca de $1 / 3$ a $1 / 2$ do investimento total, era realizado pelo governo como forma de implementar o processo de substituição de importações e criar a estrutura industrial brasileira. Assim, durante o período de implementação dos planos PED, Metas e Bases e I PND havia o objetivo de manter altos níveis de investimento. Neste fase, que correspondeu ao "Milagre Econômico", o país atingiu uma taxa de investimento média anual de $22,4 \%$ do PIB. Esta taxa continuou elevada durante o II PND (24,4\% em média), com fortes investimentos das empresas estatais, embora a economia já iniciasse uma fase de retração.

Nos planos de desenvolvimento elaborados após o II PND o objetivo de aumentar o nível de investimento no Brasil se manteve, ainda que estes planos passassem a evitar a quantificação de tal meta. Somente a partir do PPA-96 pôde-se novamente encontrar valores específicos estipulados como previsão do governo para o indicador do investimento.

Observa-se uma queda contínua da taxa de investimento partir do período que compreende os planos III PND, I PND-NR, PAG e o PPA-91. A queda no investimento neste período está associada àcrise fiscal do Estado, que gerou uma diminuição drástica no investimento governamental e à elevação da dívida externa e da inflação.

Desta forma, embora os planos após o II PND apresentassem como objetivo o crescimento dos investimentos, a ausência de uma política 
específica de incentivo à formação de capital, dado que, na prática estes planos não foram implementados, também pode ser considerada como fator desestimulador do investimento.

A partir do PPA-96, a preocupação em elevar o nível de formação de capital voltou a apresentar maior relevância, embora o padrão de intervenção estatal e de política industrial tenha se modificado. Este novo padrão de intervenção estatal está associado ao processo de mudanças que se iniciou na economia brasileira nos anos 90: as privatizações, a globalização, a abertura comercial e a estabilidade da inflação. Neste novo cenário, o Estado não mais atua como produtor e principal responsável pela formação de capital, mas assume uma postura de caráter mais indicativo. Contudo, a recuperação na taxa de investimento a partir de 1994 parece estar mais relacionada aos efeitos do Plano Real do que aos resultados do novo padrão de intervenção estatal ou de uma política de desenvolvimento governamental.

Com a estabilidade da inflação, alcançada a partir do Plano Real, esperava-se uma elevação significativa da taxa de investimento. Segundo o Plano Plurianual de 1996, as taxas de investimento previstas para os anos de 1996, 1997, 1988 e 1999 seriam de 19,0, 19,5, 20,0 e 20,5\% respectivamente. No entanto, embora tenha havido uma certa recuperação, as taxas percentuais efetivas foram de 16,54 (96), 17,88 (97), 17,49 (98) e 16,11 (99), segundo os dados do IPEA.

A política de elevação da taxa de juros, associada àinst abilidades no setor externo e riscos cambiais, é apontada como fator inibidor do investimento a partir de 1997. Estes fatores continuaram afetando a taxa de investimento que, em 2000, foi de apenas $15,68 \%$ do PIB e, em 2001, foi de $16,54 \%$. A manutenção da taxa de investimento nestes níveis tem proporcionado impactos negativos sobre o emprego e sobre o ritmo de crescimento econômico no Brasil. 


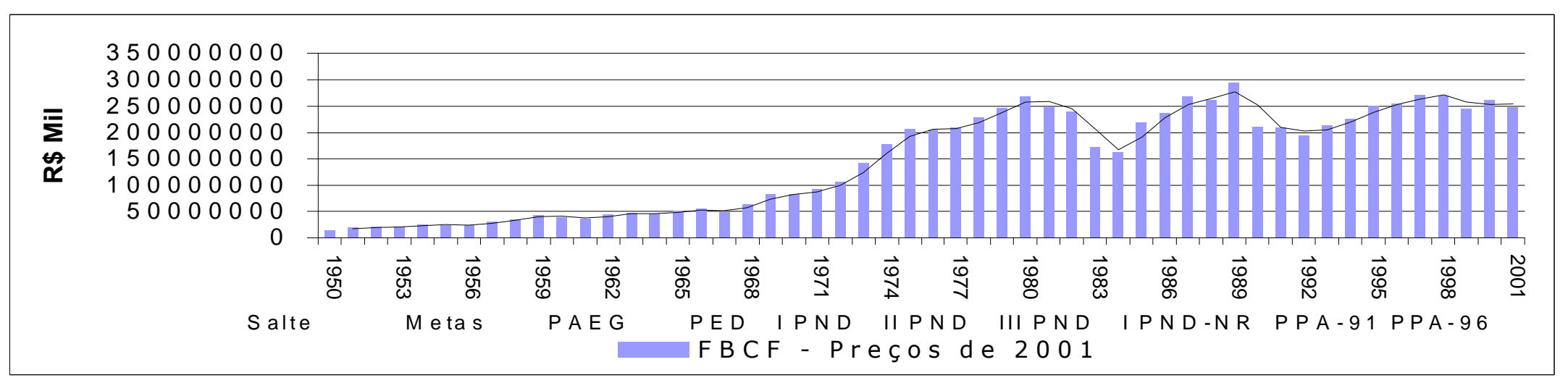

Figura 3 - Formação bruta de capital fixo 1950-2001.

Fonte: IPEA (2002)

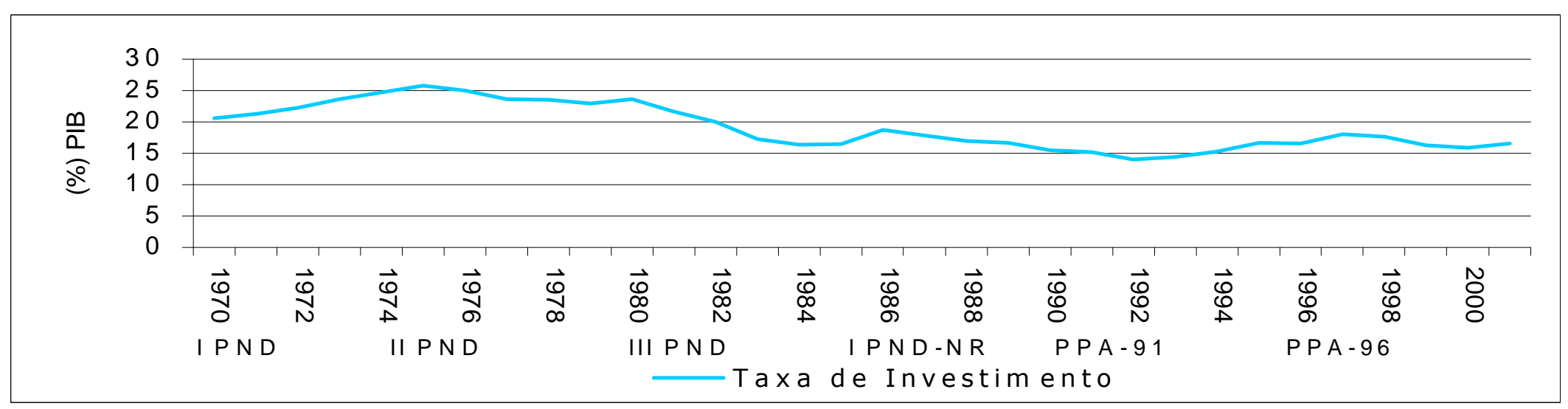

Figura 4 - Taxa de investimento 1970 - 2001 (preços 1980).

Fonte: IPEA (2002) 
Tabela 21. Planos de desenvolvimento e investimento.

\begin{tabular}{|c|c|c|c|c|}
\hline Ano & Plano & $\begin{array}{c}\text { FBCF }^{1} \\
\text { (R\$ Bilhões) }\end{array}$ & $\begin{array}{c}\text { Taxa de } \\
\text { Investimento }^{2} \\
(\% \mathrm{PIB})\end{array}$ & $\begin{array}{c}\text { Taxa de } \\
\text { Investimento } \\
(\% \mathrm{PIB}))\end{array}$ \\
\hline $\begin{array}{l}1950 \\
1951\end{array}$ & Plano Salte & $\begin{array}{l}14,9 \\
19,1\end{array}$ & & $\begin{array}{l}12,7 \\
15,4\end{array}$ \\
\hline $\begin{array}{l}1952 \\
1953 \\
1954 \\
1955\end{array}$ & & $\begin{array}{l}20,6 \\
20,6 \\
25,3 \\
24,1\end{array}$ & & $\begin{array}{l}14,8 \\
15,0 \\
15,7 \\
13,4\end{array}$ \\
\hline $\begin{array}{l}1956 \\
1957 \\
1958 \\
1959 \\
1960 \\
1961\end{array}$ & Plano de Metas & $\begin{array}{l}24,1 \\
30,8 \\
35,5 \\
43,5 \\
38,2 \\
36,1\end{array}$ & & $\begin{array}{l}14,4 \\
15,0 \\
16,9 \\
17,9 \\
15,7 \\
13,1\end{array}$ \\
\hline $\begin{array}{l}1962 \\
1963\end{array}$ & Plano Trienal & $\begin{array}{l}44,7 \\
47,1\end{array}$ & & $\begin{array}{l}15,5 \\
17,0\end{array}$ \\
\hline $\begin{array}{l}1964 \\
1965 \\
1966 \\
1967\end{array}$ & PAEG & $\begin{array}{l}45,2 \\
51,2 \\
54,4 \\
49,2\end{array}$ & & $\begin{array}{l}14,9 \\
14,7 \\
15,9 \\
16,1\end{array}$ \\
\hline $\begin{array}{l}1968 \\
1969 \\
1970\end{array}$ & PED & $\begin{array}{l}64,3 \\
81,7 \\
81,9\end{array}$ & 20,5 & $\begin{array}{l}18,6 \\
19,1 \\
18,8\end{array}$ \\
\hline $\begin{array}{l}1971 \\
1972 \\
1973 \\
1974\end{array}$ & $\begin{array}{l}\text { Metas e Bases } \\
\quad \text { I PND }\end{array}$ & $\begin{array}{c}93,7 \\
106,9 \\
142,7 \\
178,1\end{array}$ & $\begin{array}{l}21,3 \\
22,2 \\
23,6 \\
24,7\end{array}$ & $\begin{array}{l}19,9 \\
20,3 \\
20,3 \\
21,8\end{array}$ \\
\hline $\begin{array}{l}1975 \\
1976 \\
1977 \\
1978 \\
1979\end{array}$ & II PND & $\begin{array}{l}207,3 \\
204,9 \\
209,7 \\
229,1 \\
246,5\end{array}$ & $\begin{array}{l}25,8 \\
25,0 \\
23,5 \\
23,5 \\
22,8\end{array}$ & $\begin{array}{l}23,3 \\
22,4 \\
21,3 \\
22,2 \\
23,3\end{array}$ \\
\hline $\begin{array}{l}1980 \\
1981 \\
1982 \\
1983 \\
1984 \\
1985\end{array}$ & III PND & $\begin{array}{l}267,9 \\
249,8 \\
239,7 \\
171,9 \\
163,5 \\
218,4\end{array}$ & $\begin{array}{l}23,5 \\
21,6 \\
19,9 \\
17,2 \\
16,3 \\
16,4\end{array}$ & $\begin{array}{l}23,5 \\
24,3 \\
22,9 \\
19,9 \\
18,9 \\
18,0\end{array}$ \\
\hline $\begin{array}{l}1986 \\
1987 \\
1988 \\
1989 \\
1990\end{array}$ & I PND-NR/PAG & $\begin{array}{l}237,3 \\
267,8 \\
260,7 \\
293,7 \\
210,7\end{array}$ & $\begin{array}{l}18,8 \\
17,9 \\
17,0 \\
16,7 \\
15,5\end{array}$ & $\begin{array}{l}20,0 \\
23,1 \\
24,3 \\
26,8 \\
21,5\end{array}$ \\
\hline
\end{tabular}


Tabela 21. Planos de desenvolvimento e investimento.

\begin{tabular}{ccccc}
\hline Ano & Plano & $\begin{array}{c}\text { PIB } \\
\text { Preços 2000 } \\
\text { (R\$ Bilhões) }\end{array}$ & $\begin{array}{c}\text { PIB } \\
\text { Taxa de } \\
\text { Crescimento } \\
(\%)\end{array}$ & $\begin{array}{c}\text { Média } \\
(\%)\end{array}$ \\
\hline 1991 & & 209,4 & 15,1 & 18,7 \\
1992 & PPA-91 & 195,4 & 13,9 & 18,8 \\
1993 & & 214,8 & 14,1 & 19,2 \\
1994 & & 225,4 & 15,1 & 19,6 \\
1995 & 250,7 & 16,6 & 19,2 \\
1996 & & 255,3 & & \\
1997 & PPA-96 & 271,8 & 16,5 & \\
1998 & & 269,8 & 18,0 & \\
1999 & & 245,3 & 17,7 & \\
2000 & & & 16,2 & \\
2001 & PPA-2000 & 260,6 & 15,8 & \\
\hline
\end{tabular}

Fonte: IPEA (2002)

${ }^{1}$ - preços de 2001, ${ }^{2}$ - preços de $1980,{ }^{3}$ - preços correntes.

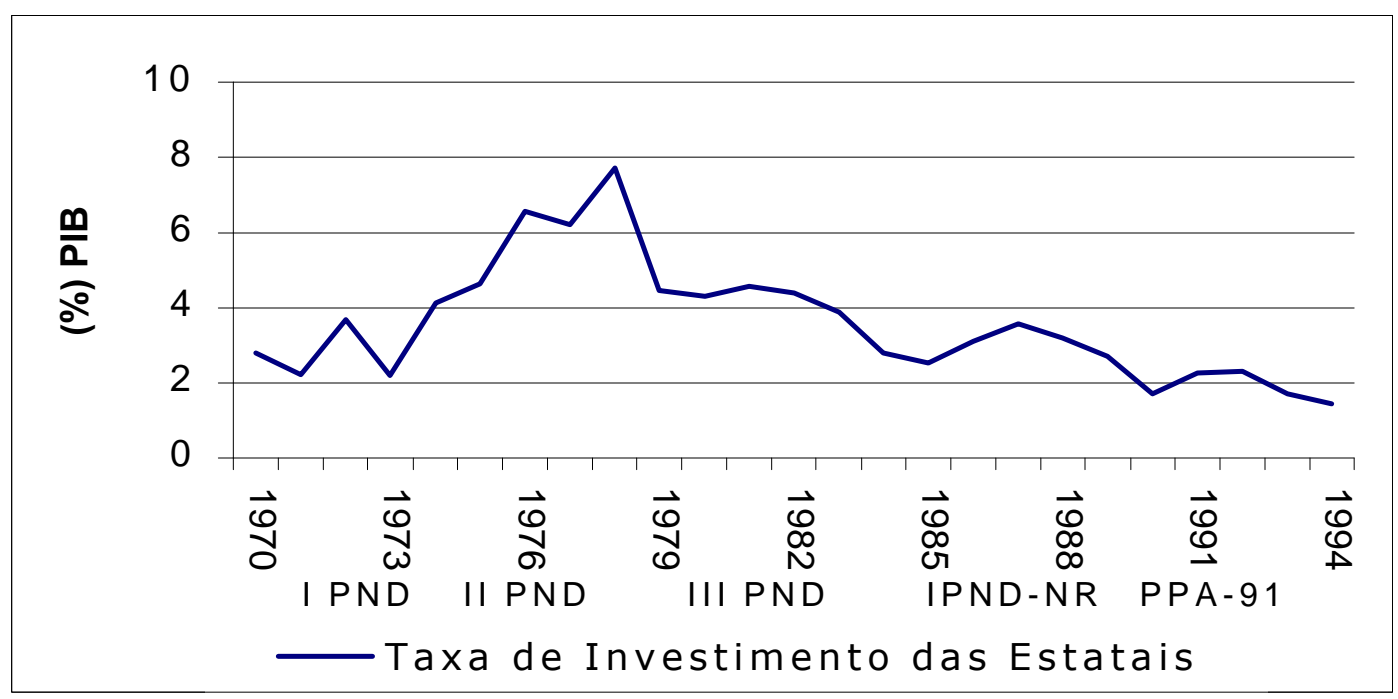

Figura 5 - Investimento das empresas estatais 1970 - 1994.

Fonte: IPEA (2002) 
Tabela 22. Investimento das estatais 1970-1994.

\begin{tabular}{|c|c|c|}
\hline Ano & Plano & Investimento Estatais* \\
\hline 1970 & PED & 2,81 \\
\hline 1971 & & 2,23 \\
\hline 1972 & Metas e Bases & 3,69 \\
\hline 1973 & I PND & 2,2 \\
\hline 1974 & & 4,14 \\
\hline 1975 & & 4,64 \\
\hline 1976 & & 6,57 \\
\hline 1977 & II PND & 6,21 \\
\hline 1978 & & 7,72 \\
\hline 1979 & & 4,46 \\
\hline 1980 & & 4,3 \\
\hline 1981 & & 4,58 \\
\hline 1982 & & 4,4 \\
\hline 1983 & III PND & 3,87 \\
\hline 1984 & & 2,79 \\
\hline 1985 & & 2,53 \\
\hline 1986 & & 3,11 \\
\hline 1987 & & 3,58 \\
\hline 1988 & & 3,2 \\
\hline 1989 & I PND-NR/PAG & 2,72 \\
\hline 1990 & & 1,72 \\
\hline 1991 & & 2,28 \\
\hline 1992 & & 2,3 \\
\hline 1993 & PPA-91 & 1,7 \\
\hline 1994 & & 1,45 \\
\hline
\end{tabular}

Fonte: IPEA (2002)

*Formação Bruta de Capital das Empresas Estatais como percentual do PIB. 


\subsubsection{Produção setorial}

\section{Indústria}

O processo de industrialização brasileiro teve início nos anos 30 se intensificando a partir da década de 50 com o processo de substituição de importações. No período de 1950 a 1961, a produção industrial triplicou e a participação da indústria no PIB passou de $24,1 \%$ para $32,5 \%$. Neste período houve um aumento da participação de setores mais intensivos em capital, como o setor de bens de consumo duráveis. Essa maior participação deveu-se ao Plano de Metas que, considerando a existência de uma demanda interna reprimida por estes bens, passou a estimular a produção do setor.

O período seguinte $(1962 / 1967)$ é caracterizado como a primeira crise industrial no Brasil. Ao longo desse período o crescimento foi de apenas 15\% e, nos anos de 1963 e 1965 (durante o PAEG), o crescimento foi nulo e negativo respectivamente.

A partir de 1967, na fase do "Milagre Econômico" a indústria foi o setor mais dinâmico com crescimento médio de $14 \%$ a.a. Com a implementação do PED e do I PND, manteve-se a tendência de maior crescimento no setor de bens de consumo duráveis. Posteriormente, o desenvolvimento industrial é caracterizado pelos investimentos estatais e incentivos governamentais ao setor privado com o objetivo de desenvolver o setor de bens intermediários e de capital. Esta fase prevaleceu durante a implementação do II PND (observe a figura 5).

Durante o II PND, as taxas de crescimento industrial foram menores do que as ocorridas durante o "Milagre" porém foram responsáveis por uma mudança estrutural na economia que teve então completada a sua matriz industrial. Apesar disto, vários problemas permaneceram na estrutura industrial brasileira como, por exemplo, a falta de competitividade de diversos setores, as dificuldades em se avançar para setores 
tecnologicamente mais avançados e a ausência de um desenvolvimento autônomo de tecnologia.

Como o setor industrial tornou-se o centro dinâmico do crescimento do PIB, a década de 80 marcada pela crise cambial, fiscal e aceleração inflacionária gerou também uma crise para a indústria. Em 1981 houve queda no produto industrial de 8,84\%. Em 1982 a indústria ficou estagnada e em 1983 voltou a cair. No período de 1984 a 1986 houve uma recuperação com crescimento acumulado em torno de 30\%. Já em 1987, a produção industrial entrou novamente em queda, recuperando-se a partir de 1993.

Nos anos 80, dada a crise fiscal, houve também uma profunda redução no investimento público que era o grande responsável pelo investimento em diversos setores como, por exemplo, no de infra-estrutura. Como conseqüência, ocorreu uma deterioração da infra-estrutura elevando os custos das empresas, além do aumento na carga tributária que penalizou ainda mais o setor industrial.

Durante o governo Collor há uma busca por maior eficiência e por ganhos de produtividade pelas empresas devido ao processo de abertura comercial. Com o fim do protecionismo e a necessidade de sobreviver em meio के crises econômicas, diversos setores da indústria iniciaram um processo de modernização e de busca de competitividade internacional. Porém, grande parte deste ajustamento foi realizado por meio de mudanças nas relações de trabalho com impactos negativos sobre o emprego industrial.

Segundo Vasconcellos et. al. (1999), nos anos 80 e 90 a manutenção de taxas de juros elevadas e a ausência de linhas de financiamento adequadas inviabilizavam os investimentos em novas tecnologias, o que dificultou a reversão da defasagem de competitividade de grande parte das indústrias nacionais. De fato, durante os anos 80 , os planos de desenvolvimento como o III PND, O I PND-NR e o PAG, não contemplavam medidas explícitas para viabilizar 0 desenvolvimento industrial. 
A partir dos anos 90, após uma década de ausência da política industrial, houve o desenvolvimento de uma nova política industrial que enfatizava o crescimento da produtividade e da competitividade das empresas por meio da abertura comercial. Esta resultou em ganhos de produtividade na indústria, conforme aponta o gráfico 11 , mas com reduzido crescimento do PIB industrial.

\section{Agricultura}

A agricultura apresentou um forte declínio de sua participação do PIB como decorrência do crescimento da indústria a partir, principalmente, da década de 50.

Contudo, apesar desta diminuição, a agricultura continuou a desempenhar importantes funções na economia, inclusive no processo de industrialização. Em geral, considera-se como funções desempenhadas pela agricultura a liberação de mão-de-obra, o fornecimento de alimentos e matérias-primas, a transferência de capital, a geração de divisas e a criação de um mercado consumidor para a indústria.

O país passou por fases de redução e crescimento da oferta agrícola mas, segundo Vasconcellos et.al. (1999), de um modo geral, a agricultura expandiu-se e diversificou-se, de modo que, com algumas dificuldades, cumpriu seu papel no processo, apesar de ser dificultada pela política econômica do governo.

Nos planos de desenvolvimento das décadas de 60 e 70 a prioridade era o desenvolvimento industrial, entretanto, com a instituição do PAEG em 1964, os gestores da política econômica procuraram criar um novo arcabouço institucional para a política agrícola visando a modernização do setor. Neste novo arcabouço foi criado o Sistema Nacional de Crédito Rural (SNCR), que prevaleceu durante os anos 70 e início dos anos 80 e a Política de Garantia de Preços Mínimos (PGPM) ambos importantes para a 
modernização da agricultura, assim como a criação da Empresa Brasileira de Pesquisa Agropecuária (EMBRAPA).

O processo de modernização foi marcado pelo aumento do grau de mecanização e quimificação das fazendas, resultando em aumento da produtividade, aumento da produção, expansão da área cultivada, crescimento da agroindústria, aumento da concentração fundiária e piora na distribuição de renda do setor.

$\mathrm{Na}$ década de 80, a agricultura teve um desempenho considerado satisfatório diante da retração da indústria. Observa-se que se não fosse o desempenho da agricultura, a crise da década de 80 poderia ter sido mais acentuada. Foram verificadas apenas crises conjunturais no setor agrícola em 1986 e 1990 decorrentes de problemas climáticos, enquanto o setor industrial sofreu uma crise de maior duração.

Este desempenho positivo na década de 80 deve-se ao processo de modernização e ao crescimento da agricultura voltada para a exportação que se beneficiou de mecanismos cambiais.

Nos anos 80, devido àcrise fiscal, ocorreu também uma mudança na política agrícola com a eliminação de subsídios, indexação do crédito rural, permitindo a prática de juros reais positivos e o uso mais intenso do Programa de Preços Mínimos (muitas vezes utilizado no sentido de conter a inflação). Ao longo dos anos 80 , o crédito agrícola se retraiu em mais de $50 \%$ e, além da redução, houve um encarecimento do crédito.

Nos anos 90, as dificuldades fiscais e orçamentárias impediram uma atuação mais eficaz da política agrícola. Esta se manteve indefinida uma vez que não foi criada uma estrutura institucional para substituir a estrutura criada na década de 60 e que acabou por se deteriorar com a crise dos anos 80.

No entanto, nos PPA's de 1996 e de 2000, o governo propôs medidas de estímulo àagricultura, como o aperfeiçoamento do Programa de Preços Mínimos e do PROAGRO, o programa da Reforma Agrária e o desenvolvimento do PRONAF. 


\section{Serviços}

O setor de serviços é o de maior participação no produto e no emprego, correspondendo a mais de $50 \%$ do PIB, porém a complexidade deste setor dificulta a sua análise.

A partir dos anos 50 houve um significativo avanço no setor, o que é uma característica natural do desenvolvimento econômico, contudo, no caso brasileiro, este crescimento, principalmente nas últimas décadas, apresentou algumas particularidades.

Considera-se que o setor de serviços tem um comportamento cíclico e que, embora ele nunca seja o carro-chefe da economia, tende a acompanhar o desempenho do setor dinâmico, seja este a agricultura ou a indústria. Assim, o setor não determina o ciclo econômico, mas é determinado por este.

Nas décadas de 70 e 80 houve grande retração no emprego rural, fruto da modernização agrícola, que não foi acompanhada por um aumento equivalente no emprego industrial. Assim, o excedente da mão-de-obra foi absorvido no setor de serviços. Outro fator de crescimento do setor terciário foi o crescimento do sistema financeiro.

No Brasil, o sistema financeiro começou a se modernizar a partir da reforma financeira de 1964 introduzida pelo PAEG. A reforma ampliou o sistema e desenvolveu órgãos específicos para o financiamento do investimento como o BNDE e a Carteira de Crédito Agrícola e Industrial (CREAI), que funcionava através do Banco do Brasil, além de recursos da Previdência Social. Estes órgãos foram responsáveis por parte do financiamento dos projetos presentes nos planos de desenvolvimento dos anos 70 .

A reforma realizada pelo PAEG eliminou a Lei da Usura e introduziu a correção monetária permitindo prática de juros reais positivos e estimulando o direcionamento de recursos para aplicações financeiras. Desta forma, o crescimento do sistema financeiro na década de 70 esteve relacionado com 
o crescimento econômico e com a dependência de intermediação financeira. Já na década de 80 , o crescimento do sistema financeiro relaciona-se com a busca de proteção contra a inflação.

Ao longo dos anos 80, o sistema financeiro apresentou uma participação superior à $10 \%$ do PIB, que é aproximadamente o dobro da participação verificada nos países desenvolvidos. Essa participação, que esteve inclusive próxima aos $20 \%$, é uma especificidade do caso brasileiro, em que quase todos os pagamentos passam pelos bancos e é também uma característica dos países que possuem altas taxas de inflação.

Assim, nos anos 90, a diminuição da participação do setor financeiro no PIB está associada àestabilização da inflação após o Plano Real.

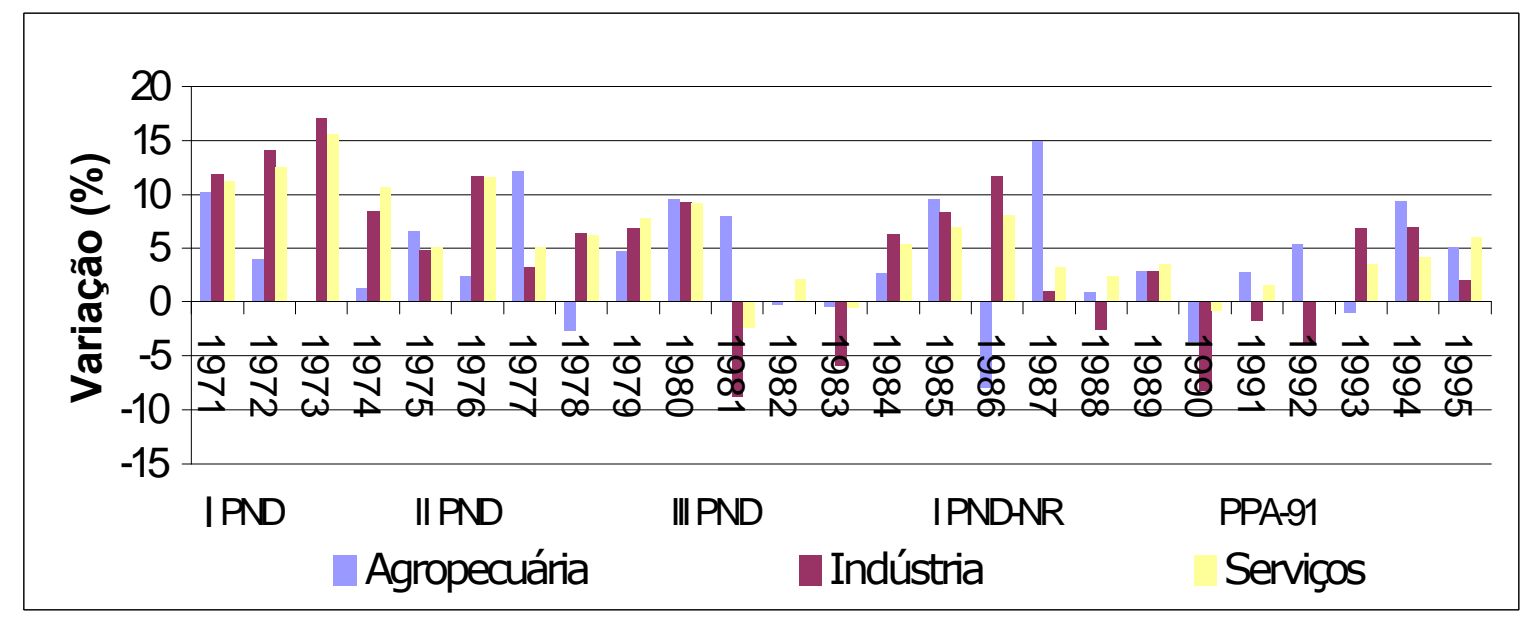

Figura 6 - Variação da produção setorial 1971-1996.

Fonte: IPEA (2002) 


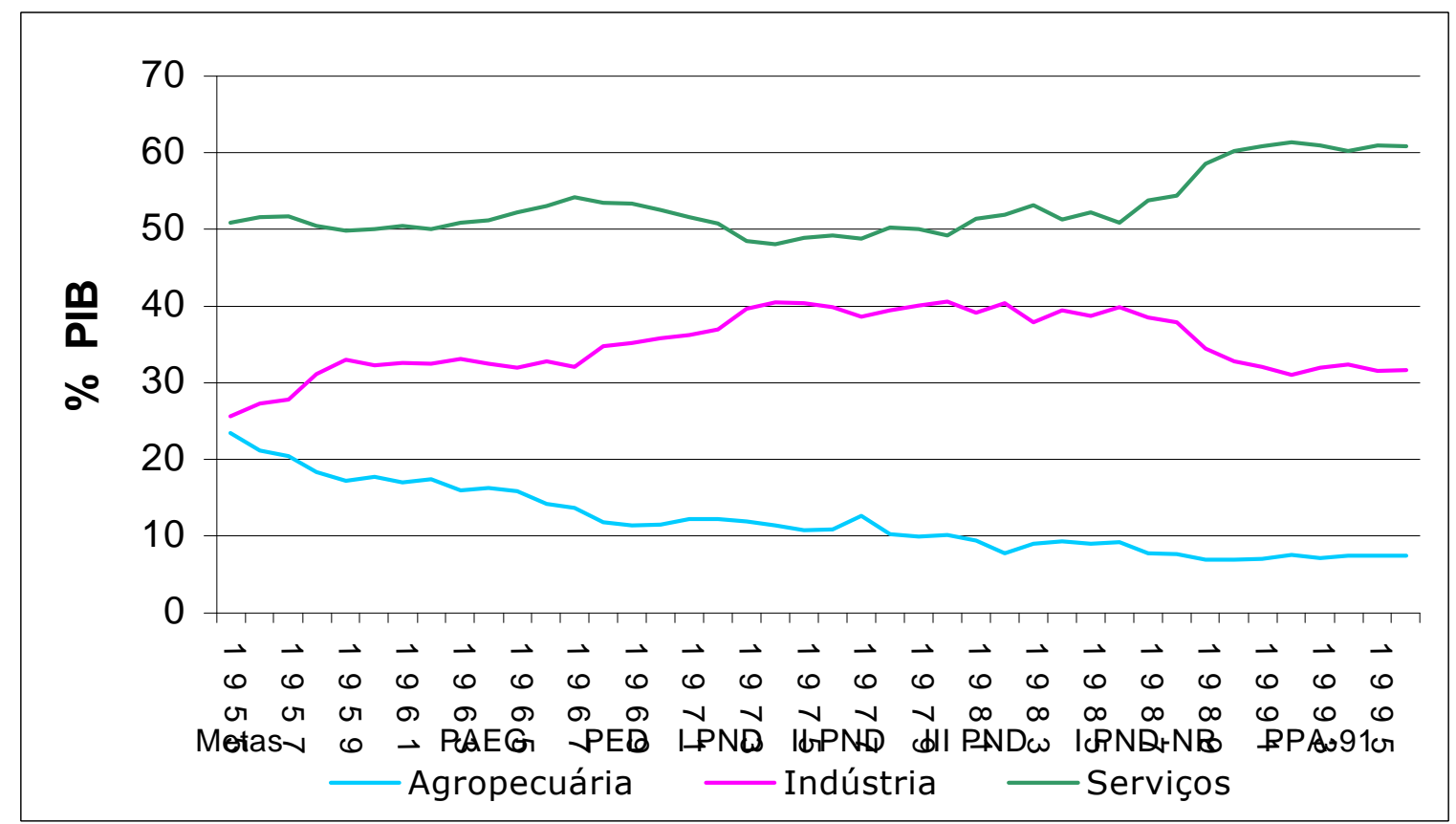

Figura 7 - Participação dos setores no PIB 1955-1996.

Fonte: IPEA (2002)

Tabela 23. Variação da produção por setores*.

\begin{tabular}{ccccc}
\hline Ano & Plano & Agropecuária & Indústria & Serviços \\
\hline 1971 & & 10,1 & 11,8 & 11,2 \\
1972 & Metas e Bases & 3,9 & 14,2 & 12,4 \\
1973 & I PND & 0,07 & 17,0 & 15,6 \\
1974 & & 1,3 & 8,5 & 10,6 \\
& & & & \\
1975 & & 6,6 & 4,9 & 5,0 \\
1976 & & 2,4 & 11,7 & 11,5 \\
1977 & II PND & 12,1 & 3,1 & 5,0 \\
1978 & & $-2,7$ & 6,4 & 6,2 \\
1979 & & 4,7 & 6,8 & 7,7 \\
& & & & \\
1980 & & 9,5 & 9,3 & 9,1 \\
1981 & & 7,9 & $-8,8$ & $-2,5$ \\
1982 & III PND & $-0,2$ & $-0,04$ & 2,1 \\
1983 & & $-0,5$ & $-5,9$ & $-0,5$ \\
1984 & & 2,6 & 6,3 & 5,3 \\
1985 & & 9,6 & 8,2 & 6,9
\end{tabular}


Tabela 23. Variação da produção por setores*.

\begin{tabular}{ccccc}
\hline Ano & Plano & Agropecuária & Indústria & Serviços \\
\hline 1986 & & $-8,0$ & 11,6 & 8,1 \\
1987 & & 14,9 & 0,9 & 3,1 \\
1988 & I PND-NR & 0,8 & $-2,6$ & 2,3 \\
1989 & PAG & 2,8 & 2,8 & 3,5 \\
1990 & & $-3,7$ & $-8,2$ & $-0,7$ \\
1991 & & 2,7 & $-1,8$ & 1,6 \\
1992 & & 5,4 & $-3,8$ & 0 \\
1993 & PPA-91 & $-1,0$ & 6,8 & 3,5 \\
1994 & & 9,3 & 6,9 & 4,2 \\
1995 & & 5,0 & 2,0 & 5,9 \\
\hline
\end{tabular}

Fonte: IPEA (2002)

*Variação percentual (\%). 
Tabela 24. Participação dos setores no PIB.

\begin{tabular}{|c|c|c|c|c|}
\hline Ano & Indústria & Agropecuária & Serviços & $\begin{array}{l}\text { Instituições } \\
\text { Financeiras }\end{array}$ \\
\hline 1955 & 25,6 & 23,5 & 50,9 & 3,4 \\
\hline 1956 & 27,3 & 21,1 & 51,6 & 3,3 \\
\hline 1957 & 27,8 & 20,4 & 51,8 & 3,6 \\
\hline 1958 & 31,1 & 18,4 & 50,5 & 3,0 \\
\hline 1959 & 33,0 & 17,2 & 49,9 & 2,8 \\
\hline 1960 & 32,2 & 17,8 & 50,0 & 2,7 \\
\hline 1961 & 32,5 & 17,0 & 50,5 & 2,8 \\
\hline 1962 & 32,5 & 17,5 & 50,1 & 2,9 \\
\hline 1963 & 33,1 & 16,0 & 51,0 & 3,0 \\
\hline 1964 & 32,5 & 16,3 & 51,2 & 3,0 \\
\hline 1965 & 32,0 & 15,9 & 52,2 & 3,4 \\
\hline 1966 & 32,8 & 14,2 & 53,1 & 3,7 \\
\hline 1967 & 32,0 & 13,7 & 54,3 & 3,8 \\
\hline 1968 & 34,8 & 11,8 & 53,5 & 4,1 \\
\hline 1969 & 35,2 & 11,4 & 53,4 & 4,4 \\
\hline 1970 & 35,8 & 11,6 & 52,6 & 6,0 \\
\hline 1971 & 36,2 & 12,2 & 51,6 & 6,1 \\
\hline 1972 & 37,0 & 12,3 & 50,8 & 6,0 \\
\hline 1973 & 39,6 & 11,9 & 48,5 & 5,4 \\
\hline 1974 & 40,5 & 11,4 & 48,1 & 5,8 \\
\hline 1975 & 40,4 & 10,8 & 48,9 & 6,6 \\
\hline 1976 & 39,9 & 10,9 & 49,2 & 7,3 \\
\hline 1977 & 38,6 & 12,6 & 48,8 & 7,5 \\
\hline 1978 & 39,5 & 10,3 & 50,3 & 8,6 \\
\hline 1979 & 40,1 & 9,9 & 50,0 & 8,4 \\
\hline 1980 & 40,6 & 10,2 & 49,2 & 7,9 \\
\hline 1981 & 39,1 & 9,5 & 51,4 & 10,0 \\
\hline 1982 & 40,3 & 7,7 & 51,9 & 9,8 \\
\hline 1983 & 37,8 & 9,0 & 53,2 & 11,4 \\
\hline 1984 & 39,4 & 9,3 & 51,3 & 10,5 \\
\hline 1985 & 38,7 & 9,0 & 52,3 & 11,0 \\
\hline 1986 & 39,9 & 9,2 & 50,9 & 7,6 \\
\hline 1987 & 38,5 & 7,7 & 53,8 & 13,1 \\
\hline 1988 & 37,9 & 7,6 & 54,5 & 12,7 \\
\hline 1989 & 34,5 & 6,9 & 58,6 & 19,5 \\
\hline 1990 & 32,8 & 6,9 & 60,3 & 13,4 \\
\hline 1991 & 32,1 & 7,1 & 60,9 & 11,4 \\
\hline 1992 & 31,1 & 7,5 & 61,4 & 13,1 \\
\hline 1993 & 31,9 & 7,1 & 61,0 & 16,3 \\
\hline 1994 & 32,4 & 7,4 & 60,3 & 13,0 \\
\hline 1995 & 31,6 & 7,4 & 61,0 & 7,6 \\
\hline 1996 & 31,7 & 7,5 & 60,9 & \\
\hline
\end{tabular}

Fonte: Vasconcellos et al. (1999) 


\subsubsection{O nível de emprego}

A elevação do nível de emprego faz parte do conjunto de objetivos dos planos de desenvolvimento elaborados no Brasil. Embora sem especificar metas, o III PND, o I PND-NR e o PAG continham elementos que buscavam a diminuição da taxa de desemprego no país. Especialmente o PAG concedeu grande ênfase àgeração de emprego (criação de 8 milhões e 400 mil novos postos de trabalho). Contudo, a implementação parcial ou quase nula dos programas concebidos nos planos não permite maior associação entre estes e o nível de emprego no país.

Observa-se que a taxa de desemprego aberto caiu durante o período no qual deveria prevalecer o I PND-NR e o PAG, se elevando a partir de 1991 (PPA-91). Nos anos 90, tem-se uma elevação no nível de desemprego e uma forte redução do emprego industrial (cerca de 25\% entre 1989 e 1995). O emprego sofreu influência dos mesmos fatores que afetaram negativamente a taxa de investimento e o crescimento do PIB, como a política de estabilização e a elevação da taxa de juros. Contudo, na década de 90, um outro aspecto é considerado relevante: a reestruturação nas empresas decorrente, entre outros fatores, da abertura comercial.

$\mathrm{O}$ ajuste e a reestruturação nas empresas levaram à redução do emprego industrial e ao crescimento da produtividade do trabalho da indústria de 30\%. Esta reestruturação implicou na adoção de técnicas de gestão, tecnologias poupadoras de trabalho e na terceirização como medidas de estímulo à produtividade e à competitividade, o que ocasionou uma elevação na taxa de desemprego.

Assim, o processo que se iniciou a partir dos anos 90, juntamente com a recessão e a competição externa, levou as empresas a modificarem a organização do trabalho, o que afetou não apenas o nível de emprego, como também a composição deste (aumento da proporção do emprego no setor de serviços). 
Nos últimos anos, a política econômica adotada, bem como a implementação dos PPA's, não tem sido capaz de reverter a situação, uma vez que a taxa de desemprego manteve-se elevada (em média 7,4\% de 2000 a 2002).

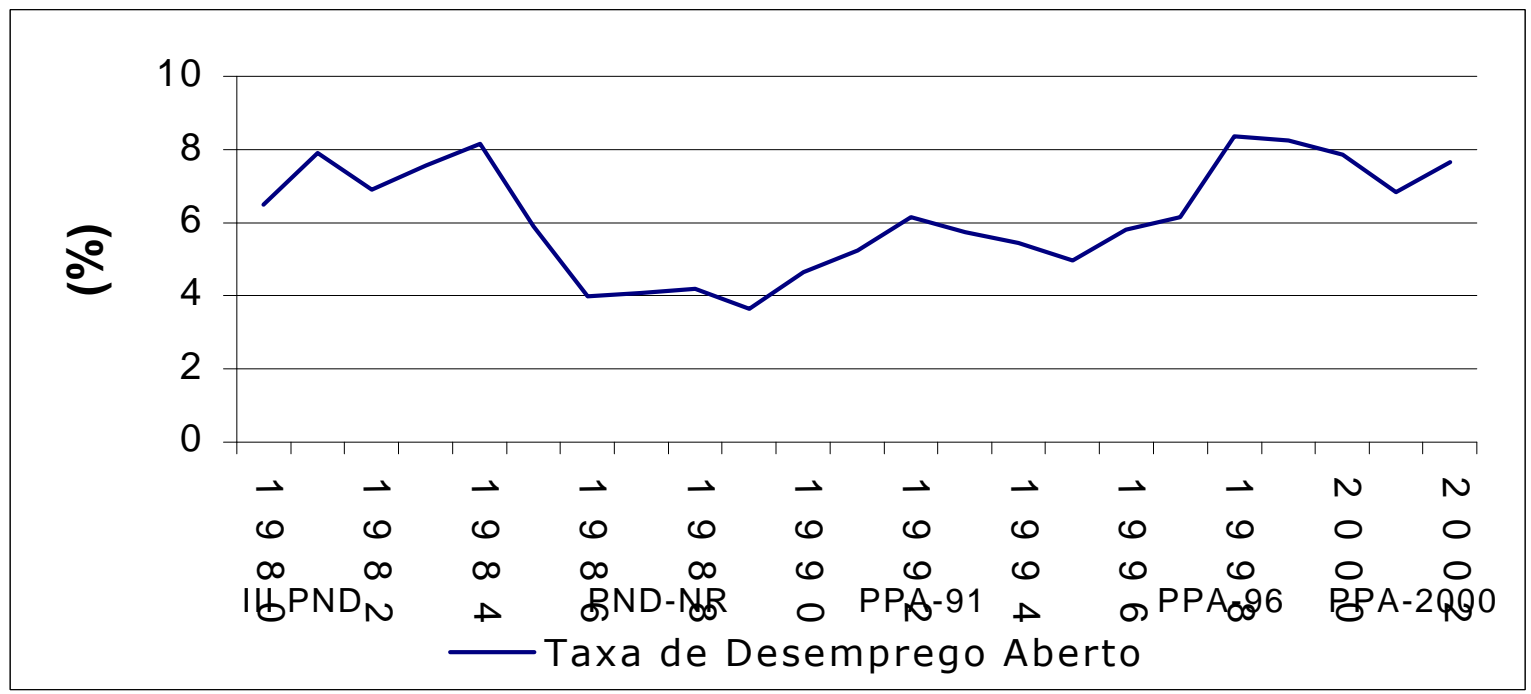

Figura 8 - Taxa de desemprego aberto 1980 - 2002.

Fonte: IPEA (2002)

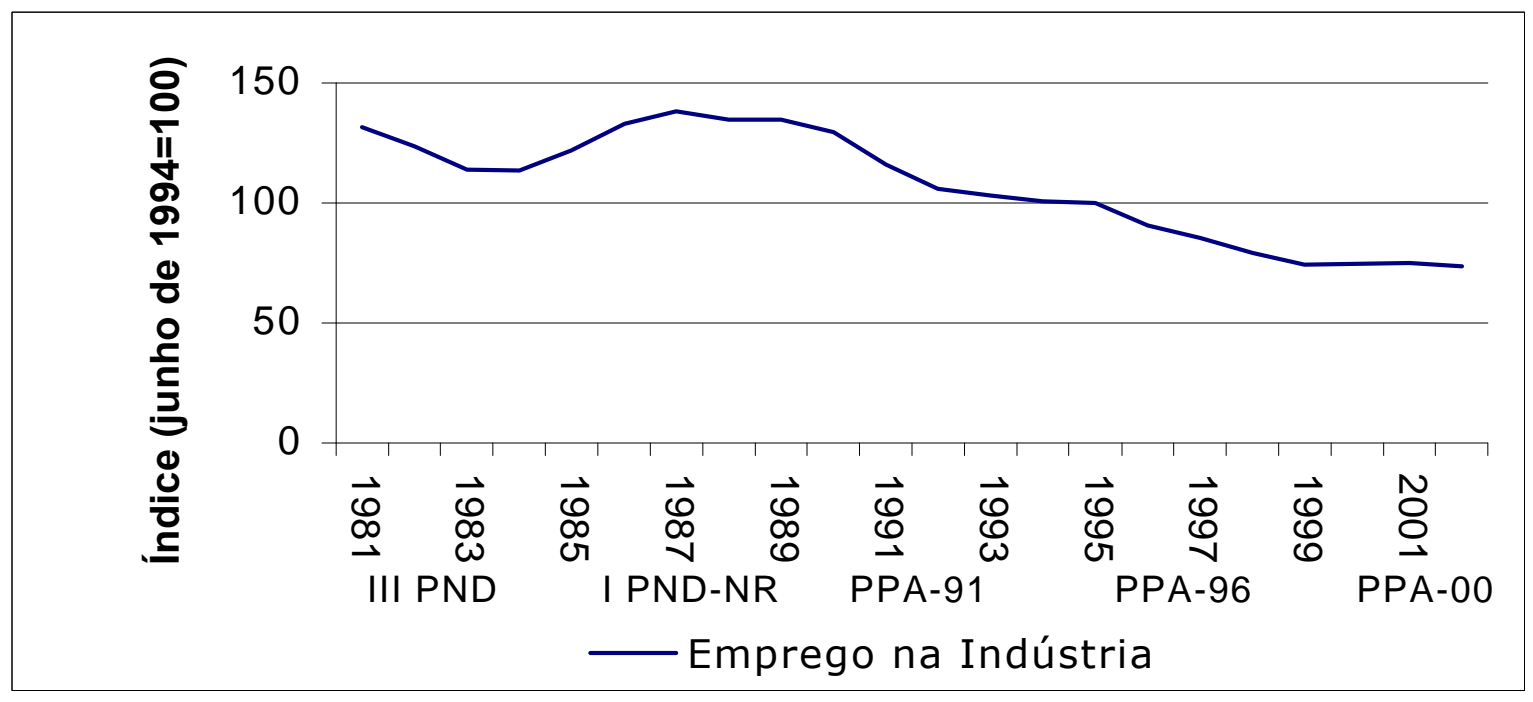

Figura 9 - Emprego na indústria 1981 - 2001.

Fonte: IPEA (2002) 
Tabela 25. Planos de desenvolvimento e nível de emprego.

\begin{tabular}{|c|c|c|c|c|c|}
\hline Ano & Plano & $\begin{array}{c}\text { Taxa de } \\
\text { Desemprego } \\
\text { Aberto }\end{array}$ & Média & $\begin{array}{l}\text { Emprego na } \\
\text { Indústria* }\end{array}$ & Média \\
\hline 1980 & & 6,5 & & & \\
\hline 1981 & & 7,9 & & 131,7 & \\
\hline 1982 & & 6,9 & & 123,6 & \\
\hline 1983 & III PND & 7,6 & 7,2 & 113,7 & 120,9 \\
\hline 1984 & & 8,1 & & 113,6 & \\
\hline 1985 & & 5,9 & & 121,6 & \\
\hline 1986 & & 3,9 & & 133,0 & \\
\hline 1987 & & 4,1 & & 138,4 & \\
\hline 1988 & I PND-NR/PAG & 4,2 & 4,1 & 134,6 & 134,02 \\
\hline 1989 & & 3,6 & & 134,6 & \\
\hline 1990 & & 4,6 & & 129,5 & \\
\hline 1991 & & 5,2 & & 115,8 & \\
\hline 1992 & & 6,1 & & 106,0 & \\
\hline 1993 & PPA-91 & 5,7 & 5,5 & 103,2 & 105,1 \\
\hline 1994 & & 5,4 & & 100,7 & \\
\hline 1995 & & 4,9 & & 99,9 & \\
\hline 1996 & & 5,8 & & 90,5 & \\
\hline 1997 & & 6,1 & & 85,5 & \\
\hline 1998 & PPA-96 & 8,3 & 7,1 & 79,1 & 82,3 \\
\hline 1999 & & 8,2 & & 74,2 & \\
\hline 2000 & & 7,8 & & 74,5 & \\
\hline 2001 & PPA-2000 & 6,8 & 7,4 & 74,8 & 74,2 \\
\hline 2002 & & 7,6 & & 73,3 & \\
\hline
\end{tabular}

Fonte: IPEA (2002)

*Índice do nível de emprego industrial em São Paulo (base: junho de 1994=100). 


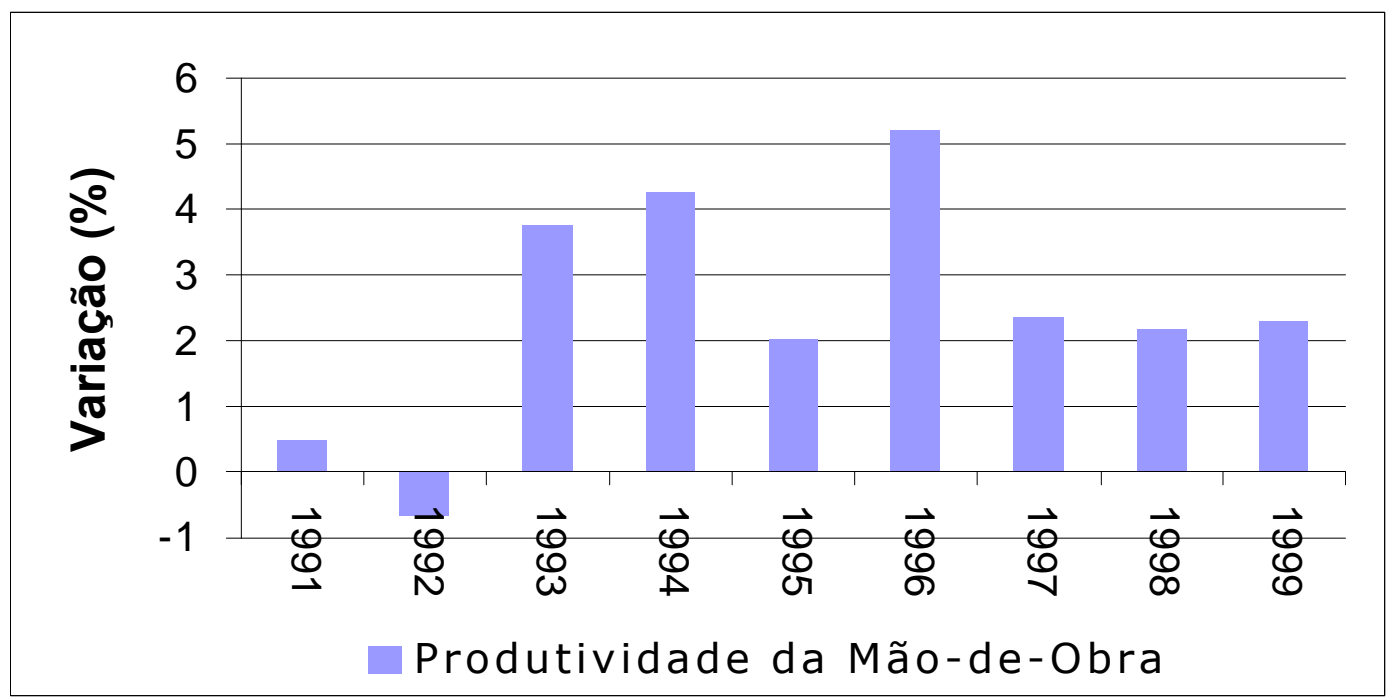

Figura 10 - Produtividade da mão-de-obra 1991-1999.

Fonte: IPEA (2002)

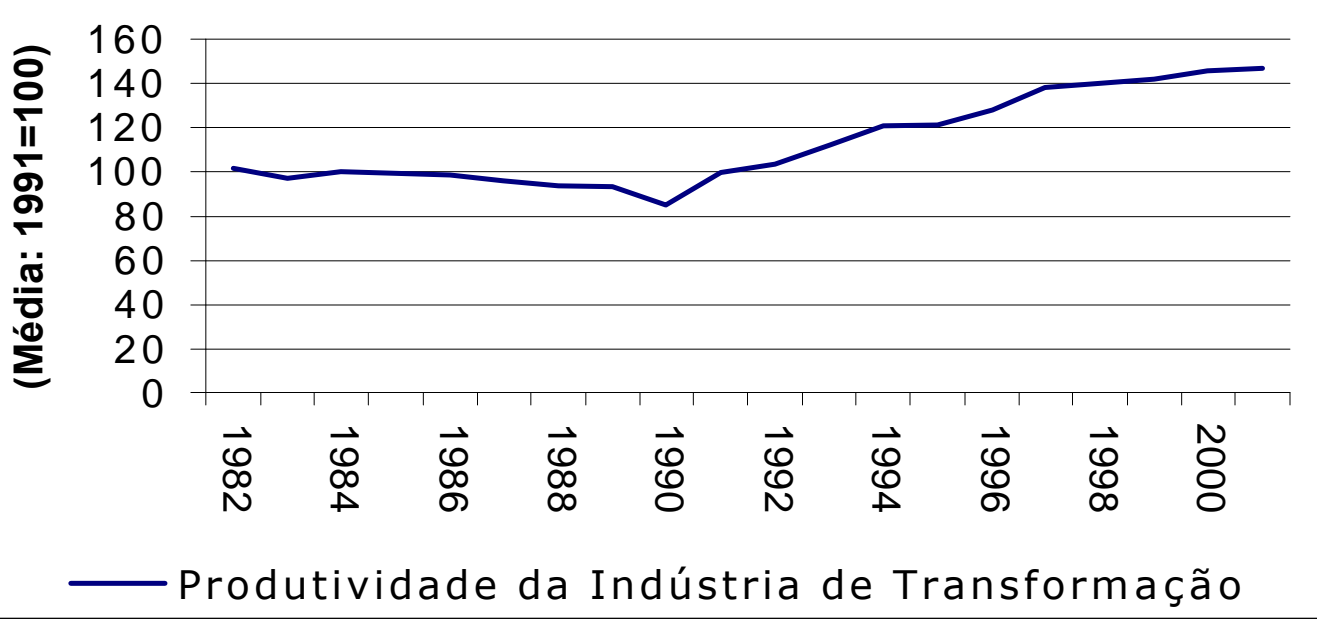

Figura 11 - Produtividade da indústria de transformação 1982-2001. Fonte: IPEA (2002) 
Tabela 26. Produtividade da indústria de transformação e da mão-de-obra.

\begin{tabular}{cccc}
\hline Ano & Plano & $\begin{array}{c}\text { Produtividade } \\
\text { Indústria de } \\
\text { Transformação* }\end{array}$ & mão-de-obra** \\
\hline 1982 & & 101,7 & \\
1983 & 96,9 & \\
1984 & III PND & 100,1 & \\
1985 & & 99,3 & \\
1986 & & 98,1 & \\
1987 & & 96,2 & \\
1988 & I PND-NR & 93,5 & \\
1989 & PAG & 93,4 & \\
1990 & & 84,9 & 0,5 \\
1991 & & 99,8 & $-0,7$ \\
1992 & & 103,5 & 3,8 \\
1993 & 112,1 & 4,3 \\
1994 & PPA-91 & 120,5 & 2,0 \\
1995 & & 121,2 & \\
1996 & & 127,9 & 5,2 \\
1997 & & 138,1 & 2,4 \\
1998 & & 140,3 & 2,2 \\
1999 & & 141,7 & 2,3 \\
2000 & PPA-96 & 145,6 & \\
2001 & & 146,5 & \\
\hline
\end{tabular}

Fonte: IPEA (2002)

* Média anual - Índice:1991=100 (índice calculado pela razão dos índices de produção industrial e a população ocupada na indústria de transformação); **Variação percentual anual. 


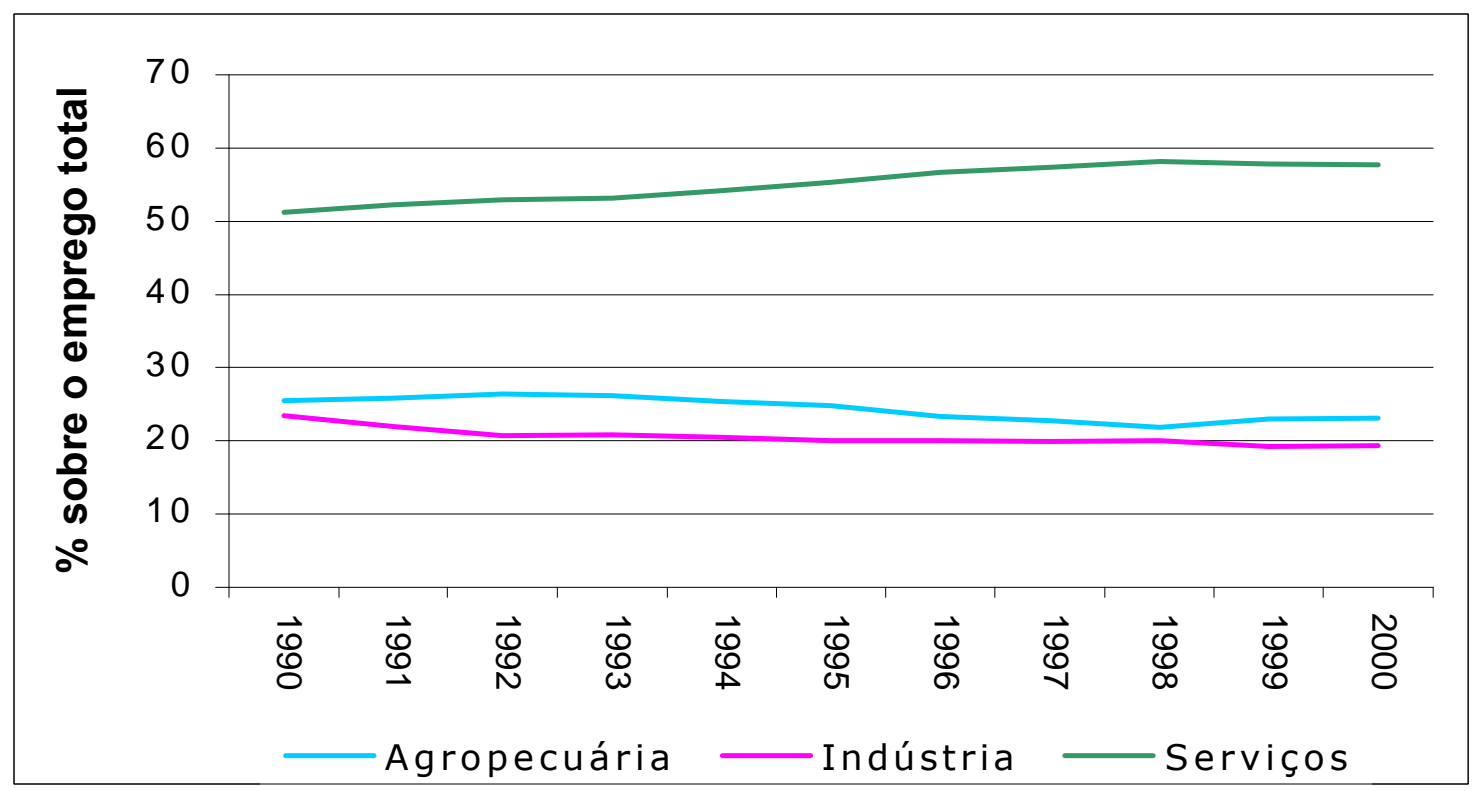

Figura 12 - Pessoal empregado por setor 1990 - 2000.

Fonte: IPEA (2002)

Tabela 27. Pessoal empregado por setor*.

\begin{tabular}{cccccccc}
\hline Ano & Agropecuária & $(\%)$ & Indústria & $(\%)$ & Serviços & $(\%)$ & Total \\
\hline 1990 & 14,91 & 25,4 & 13,68 & 23,4 & 29,98 & 51,2 & 58,58 \\
1991 & 15,27 & 25,8 & 12,94 & 21,9 & 30,83 & 52,2 & 59,03 \\
1992 & 15,64 & 26,4 & 12,28 & 20,7 & 31,33 & 52,9 & 59,25 \\
1993 & 15,57 & 26,1 & 12,43 & 20,8 & 31,63 & 53,1 & 59,63 \\
1994 & 15,37 & 25,4 & 12,37 & 20,5 & 32,67 & 54,1 & 60,41 \\
1995 & 15,16 & 24,7 & 12,24 & 20,0 & 33,83 & 55,2 & 61,23 \\
1996 & 13,91 & 23,3 & 11,98 & 20,0 & 33,88 & 56,7 & 59,76 \\
1997 & 13,68 & 22,7 & 11,97 & 19,9 & 34,47 & 57,3 & 60,12 \\
1998 & 13,29 & 21,9 & 12,14 & 19,9 & 35,34 & 58,1 & 60,77 \\
1999 & 14,36 & 23,0 & 11,99 & 19,2 & 36,06 & 57,8 & 62,42 \\
2000 & 14,89 & 23,0 & 12,50 & 19,3 & 37,24 & 57,6 & 64,62 \\
\hline
\end{tabular}

Fonte: IPEA (2002)

* Montante de pessoas empregadas por setor (em milhões). 


\subsubsection{Indicadores macroeconômicos}

\subsubsection{Inflação}

O aumento na taxa de inflação, ao longo dos anos 80 e 90, dificultou a implementação dos planos de desenvolvimento econômico. Na realidade, observa-se que há uma alternância na prioridade da política governamental nas fases de aceleração inflacionária cujos esforços de planejamento passam a se concentrar no objetivo de combater a inflação.

Nos anos 50, com o lançamento do Plano de Metas buscou-se promover o desenvolvimento industrial e foi mantida uma política monetária expansionista apesar do crescimento da inflação observado no final da década e no início dos anos 60.

Posteriormente, a fase de recessão e a aceleração inflacionária geraram planos de desenvolvimento que continham elementos que mais os aproximavam de planos de estabilização. Assim, os planos Trienal e PAEG possuíam medidas recessivas de combate à inflação embora contivessem entre os seus objetivos o crescimento econômico. Estes planos, principalmente o PAEG, tiveram impactos positivos sobre a inflação mas negativos sobre o ritmo de crescimento econômico, gerando uma alteração na política econômica a partir de 1967.

A partir de 1967 há um maior controle sobre o processo inflacionário e uma mudança no diagnóstico da inflação: de demanda para inflação de custos. Desta forma, novamente a política econômica torna-se desenvolvimentista e expansionista e são implementados os planos PED, Metas e Bases e I PND.

Apesar da diminuição no ritmo de crescimento econômico a partir de 1974 e da situação externa adversa, o governo manteve o modelo de desenvolvimento por meio do endividamento externo lançando o II PND. Nesta época, a inflação não causava grandes distorções sobre o sistema 
produtivo, de modo que havia uma possibilidade maior de se optar pelo crescimento ao invés do ajustamento.

A partir dos anos 80, o aprofundamento da crise fiscal, a elevação da dívida externa e a inflação generalizada destituíram da política governamental a capacidade de desenvolver programas que não fossem conjunturais. Tem-se a partir desta época um abandono da política desenvolvimentista (que pode ser observado no esquecimento do III PND) e a adoção de uma política antiinflacionária ortodoxa e baseada nos pressupostos do FMI.

Durante a administração da Nova República são mantidos os esforços pela estabilização mas introduzidos elementos heterodoxos nas políticas adotadas. Assim, as principais medidas adotadas pelo governo Sarney, não faziam parte do I PND-NR ou do PAG, mas sim, do Planos Cruzado, Cruzado II, Bresser e Verão. Os sucessivos fracassos destes planos relacionavam-se à múltiplas causas, principalmente à não eliminação do déficit público e ao componente inercial da inflação.

Nos anos 90, já no Governo Collor, são adotadas medidas que diminuem a taxa de inflação, que chegou a se aproximar da hiperinflação no período de 1988 a 1990. Estas medidas geraram um aprofundamento da recessão e uma crise de liquidez na economia brasileira sem, contudo, eliminar o problema da inflação que voltou a se acelerar em 1991. Novamente o planejamento para o desenvolvimento foi relegado (o PPA-91 praticamente não foi implementado) e priorizou-se a estabilização. Entretanto, neste período foi iniciado o processo de abertura comercial que fez parte também da política econômica adotada no governo posterior.

O lançamento do Plano Real foi precedido por um ajuste fiscal e patrimonial (as privatizações) e acompanhado do processo de abertura comercial e de globalização. A combinação destes fatores possibilitou um maior controle sobre a taxa de inflação, embora a manutenção de altas taxas de juros e os problemas cambiais tenham sido fatores que dificultam o crescimento da taxa de investimento e do emprego. No entanto, a queda 
drástica da inflação cria uma possibilidade maior de se concretizar políticas de desenvolvimento, indicando um maior grau de implementação dos planos plurianuais a partir de 1996.

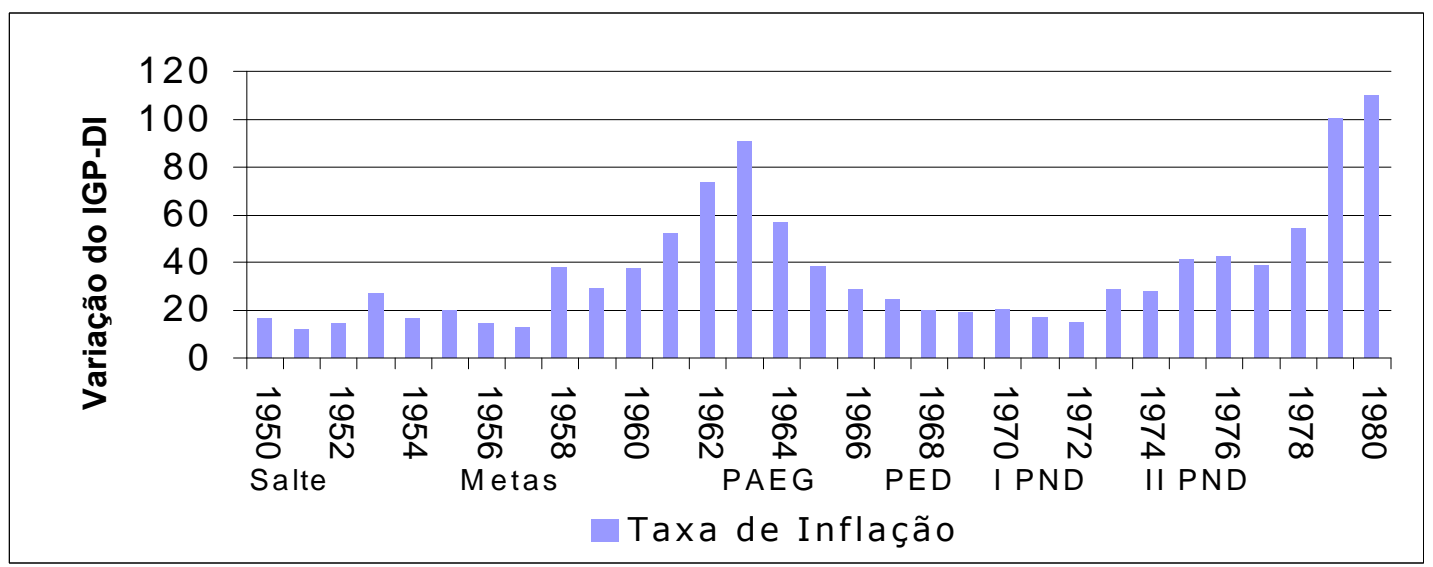

Figura 13 - Taxa de inflação 1950-1980.

Fonte: IPEA (2002)

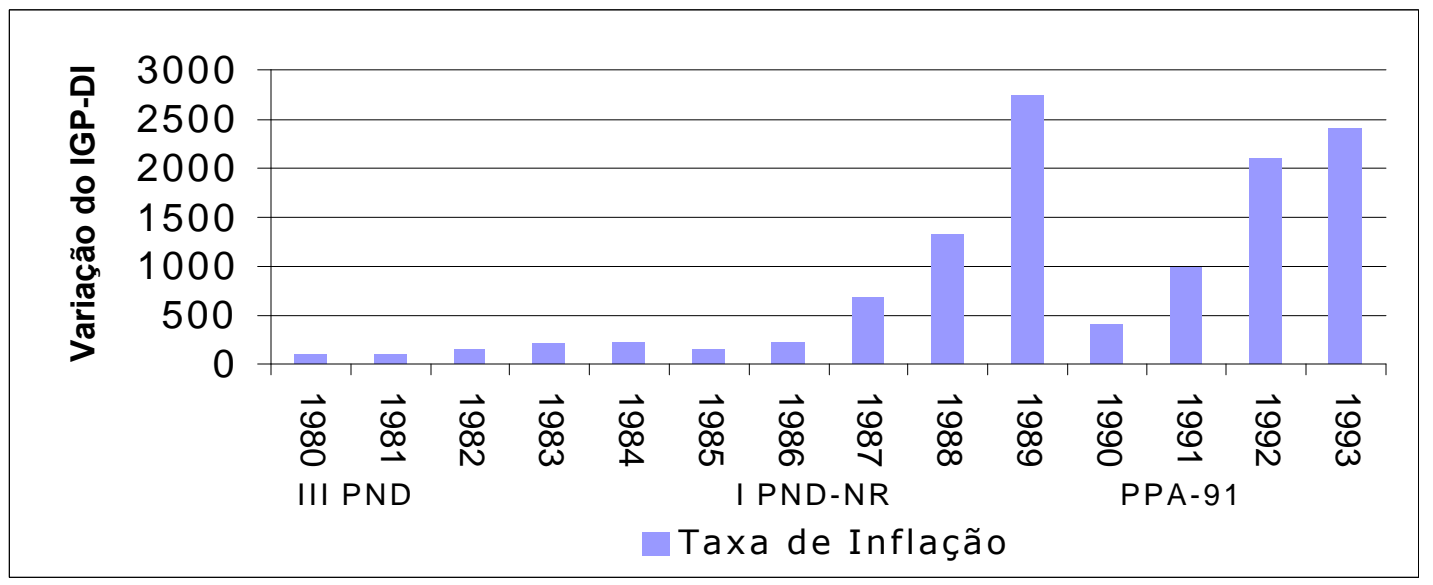

Figura 14 - Taxa de inflação 1980-1993.

Fonte: IPEA (2002) 


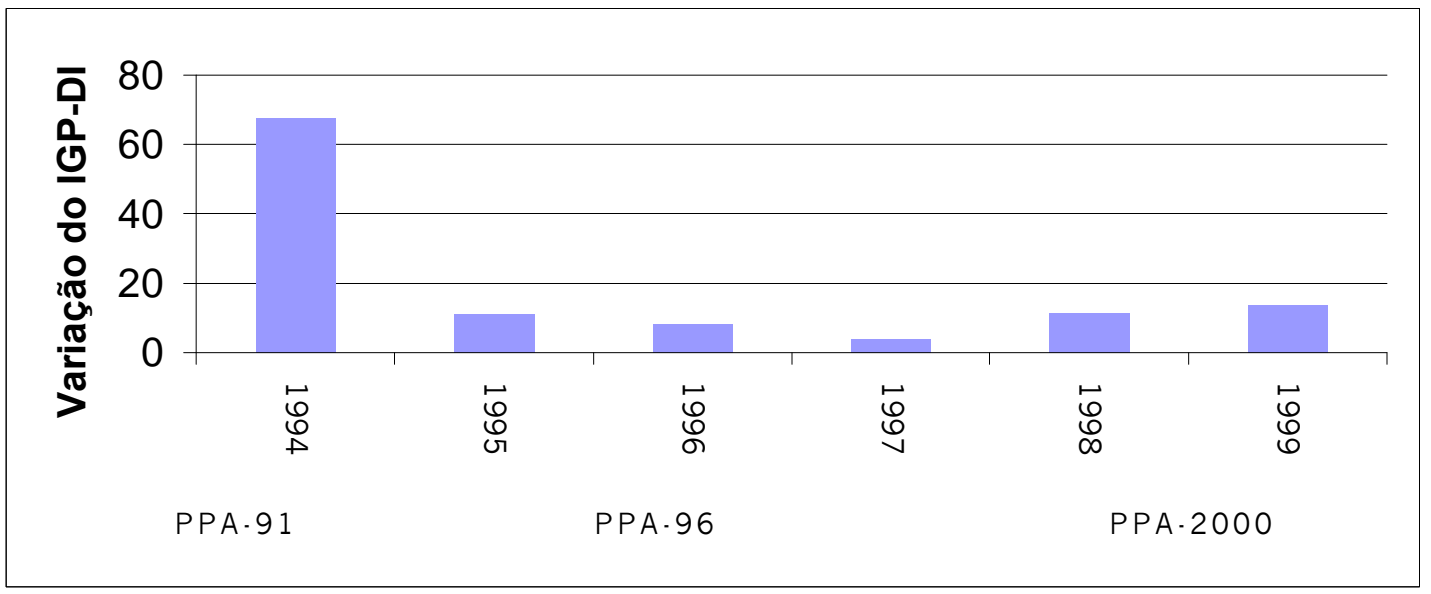

Figura 15 - Taxa de inflação 1994-1999.

Fonte: IPEA (2002)

Tabela 28. Planos de desenvolvimento e inflação.

\begin{tabular}{lccc}
\hline Ano & Plano & Inflação & Média \\
\hline 1950 & Plano Salte & 16,5 & 14,15 \\
1951 & & 11,8 & \\
1952 & & 14,5 & \\
1953 & & 27,2 & \\
1954 & & 16,1 & \\
1955 & & 19,9 & \\
1956 & & 14,2 & \\
1957 & & 13,0 & 30,5 \\
1958 & Plano de Metas & 37,9 & \\
1959 & & 29,1 & \\
1960 & & 37,2 & \\
1961 & & 51,9 & 90,6 \\
1962 & & 73,8 & \\
1963 & & 90,6 & 37,1 \\
1964 & Plano Trienal & & \\
1965 & & 57,1 & \\
1966 & & 38,5 & \\
1967 & PAEG & 28,6 & \\
1968 & & 24,2 & \\
1969 & & 20,1 & \\
1970 & & 19,4 &
\end{tabular}


Tabela 28. Planos de desenvolvimento e inflação.

\begin{tabular}{|c|c|c|c|}
\hline Ano & Plano & Inflação & Média \\
\hline $\begin{array}{l}1971 \\
1972 \\
1973 \\
1974\end{array}$ & $\begin{array}{c}\text { Metas e Bases } \\
\text { I PND }\end{array}$ & $\begin{array}{l}17,3 \\
14,9 \\
28,7 \\
27,9\end{array}$ & 22,2 \\
\hline $\begin{array}{l}1975 \\
1976 \\
1977 \\
1978 \\
1979\end{array}$ & II PND & $\begin{array}{c}41,2 \\
42,6 \\
38,7 \\
53,9 \\
100,2\end{array}$ & 55,1 \\
\hline $\begin{array}{l}1980 \\
1981 \\
1982 \\
1983 \\
1984 \\
1985\end{array}$ & III PND & $\begin{array}{c}109,9 \\
95,4 \\
154,5 \\
220,7 \\
225,5 \\
142,2\end{array}$ & 158,1 \\
\hline $\begin{array}{l}1986 \\
1987 \\
1988 \\
1989 \\
1990\end{array}$ & I PND-NR/PAG & $\begin{array}{c}224,8 \\
684,6 \\
1319,9 \\
2740,2 \\
414,7\end{array}$ & 1076,7 \\
\hline $\begin{array}{l}1991 \\
1992 \\
1993 \\
1994 \\
1995\end{array}$ & PPA-91 & $\begin{array}{c}991,3 \\
2103,1 \\
2406,9 \\
67,5 \\
11,1\end{array}$ & 1116,0 \\
\hline $\begin{array}{l}1996 \\
1997 \\
1998 \\
1999\end{array}$ & PPA-96 & $\begin{array}{c}7,9 \\
3,9 \\
11,1 \\
13,8\end{array}$ & 9,2 \\
\hline $\begin{array}{l}2000 \\
2001\end{array}$ & PPA-2000 & $\begin{array}{c}9,8 \\
10,4\end{array}$ & 10,1 \\
\hline
\end{tabular}

Fonte: IPEA (2002)

\subsubsection{Dívida externa}

O aumento do endividamento externo do país, aproveitando a liquidez do mercado internacional, ocorreu no final dos anos 60 nas fases de implementação dos planos PED, Metas e Bases e I PND (1968 a 1974). 
Neste período, a dívida externa cresceu a uma taxa média de $25 \%$ ao ano com uma mudança também na estrutura da dívida que passou a se concentrar no setor público (a participação da dívida pública passou de $26,9 \%$ para $64,1 \%$ do total da dívida externa). Assim, depois de permanecer constante nos anos 60, a dívida externa começou a crescer no final da década (de US\$3,28 bilhões em 1967 para US\$14,85 bilhões em 1973).

Procurou-se associar o rápido crescimento da dívida ao crescimento do PIB ocorrido durante o Milagre Econômico e à necessidade de se implementar os programas constantes do PED, do Metas e Bases e do I PND. Mas, segundo Lacerda et. al. (2000), esse crescimento foi financiado quase que totalmente por recursos internos. A justificativa para o endividamento neste período estaria então na alta liquidez do mercado de capitais internacional e na necessidade de assegurar um bom volume de reservas internacionais.

Já a partir de 1973, o extraordinário aumento da dívida externa estava associado ao déficit comercial, ao aumento dos juros e ao pagamento de serviços mais elevados. Entre 1973 e 1978 a maior parte da elevação da dívida ocorria devido à necessidade de cobrir o déficit em conta corrente e não `a necessidade de aumentar as reservas.

Neste período, o endividamento está associado também àdecisão de se implantar o II PND e de manter as taxas de crescimento da economia. O crescimento econômico por meio da dívida era justificado pela possibilidade de que as futuras economias de divisas, resultantes dos programas de investimentos do II PND, viessem a criar uma situação na qual o país poderia produzir superávits comerciais suficientes para pagar os juros e amortizar a dívida externa.

A dívida externa bruta aumentou de US\$14,8 bilhões em 1973 para US\$ 52,9 bilhões em 1978, com um crescimento da participação do setor público no total da dívida. 
Em 1979 houve o segundo choque do petróleo e o choque dos juros gerando um aumento do serviço da dívida e do custo de novos empréstimos (em 1979, o serviço da dívida correspondia a 63\% das exportações). Assim, a partir deste período, a elevação da dívida transformou-se em um processo autoreforçador.

A partir de 1980, o governo viu-se obrigado a mudar a política macroeconômica diante da dificuldade de financiar o déficit externo. O ajuste econômico foi feito por meio de uma política monetária restritiva e de outras medidas visando a redução da demanda agregada para controlar as importações, o que provocou um impacto recessivo no país. Esse ajuste, no entanto, não permitiu ao país a solução para o controle da dívida externa, uma vez que os déficits em conta corrente não tinham mais relação com o excesso de demanda interna por importados, mas sim com o próprio crescimento dos juros.

Em 1982, com a moratória mexicana, os mercados internacionais de crédito se fecharam para o financiamento da dívida externa latinoamericana. Este fato agravou a situação do país que nesta época possuía um serviço da dívida que absorvia $83 \%$ das receitas de exportação e não possuía mais uma oferta de crédito ao seu dispor.

Assim, a rolagem da dívida e a obtenção de novos empréstimos para pagar juros passou a depender da aprovação do FMI para um programa de ajuste no país. $O$ ajuste foi realizado e os resultados das medidas propostas pelo FMI foram, principalmente, a queda no PIB e os superávits na Balança Comercial que, por sua vez, resultaram também do impacto dos programas de substituição de importações presentes no II PND. A recessão do início dos anos 80 e a impossibilidade de se implantar o III PND revelam que a prioridade dada pela política macroeconômica के contas externas tornou-se uma fonte importante de desequilíbrio interno neste período.

A partir de 1983 e 1984 o acúmulo de reservas resultante dos superávits comerciais permitiu ao país cobrir a conta dos juros da dívida externa. No entanto, a política de austeridade defendida pelo FMI era cada 
vez mais vista de modo impopular e, desta forma, o governo Sarney, a partir de 1985, se recusou a adotar os novos programas de ajuste propostos pelo FMI. Este fato piorou as relações do país com o fundo. Além disto, houve queda no nível de investimentos estrangeiros e no nível de reservas internacionais a partir de 1986 levando o governo federal a suspender os pagamentos da dívida externa em 1987.

Posteriormente, o país voltou a efetuar os pagamentos dos juros da dívida externa, porém baseados em novos termos de acordo com o FMI e iniciando um longo processo de negociação com os credores internacionais.

A partir dos anos 90, tem início no país o movimento de liberalização financeira que intensifica o fluxo internacional de capitais. Assim, surgem novas formas de captação de recursos como, por exemplo, o lançamento de títulos públicos e de ações de empresas nacionais no exterior, caracterizando uma nova forma de endividamento externo do Brasil.

A inserção do Brasil no movimento de capitais internacional gerou uma série de mudanças no mercado cambial brasileiro e tem sido chamada de "abertura financeira". Em 1994, a nova forma de endividamento tornouse a base da renegociação feita durante o governo de Itamar Franco, na qual parte da dívida externa bancária foi substituída por títulos do governo brasileiro. Este processo, conhecido como securitização foi a forma encontrada para solucionar a crise da dívida externa e tem sido utilizada nos últimos anos como forma de garantir a entrada de recursos externos no país. 


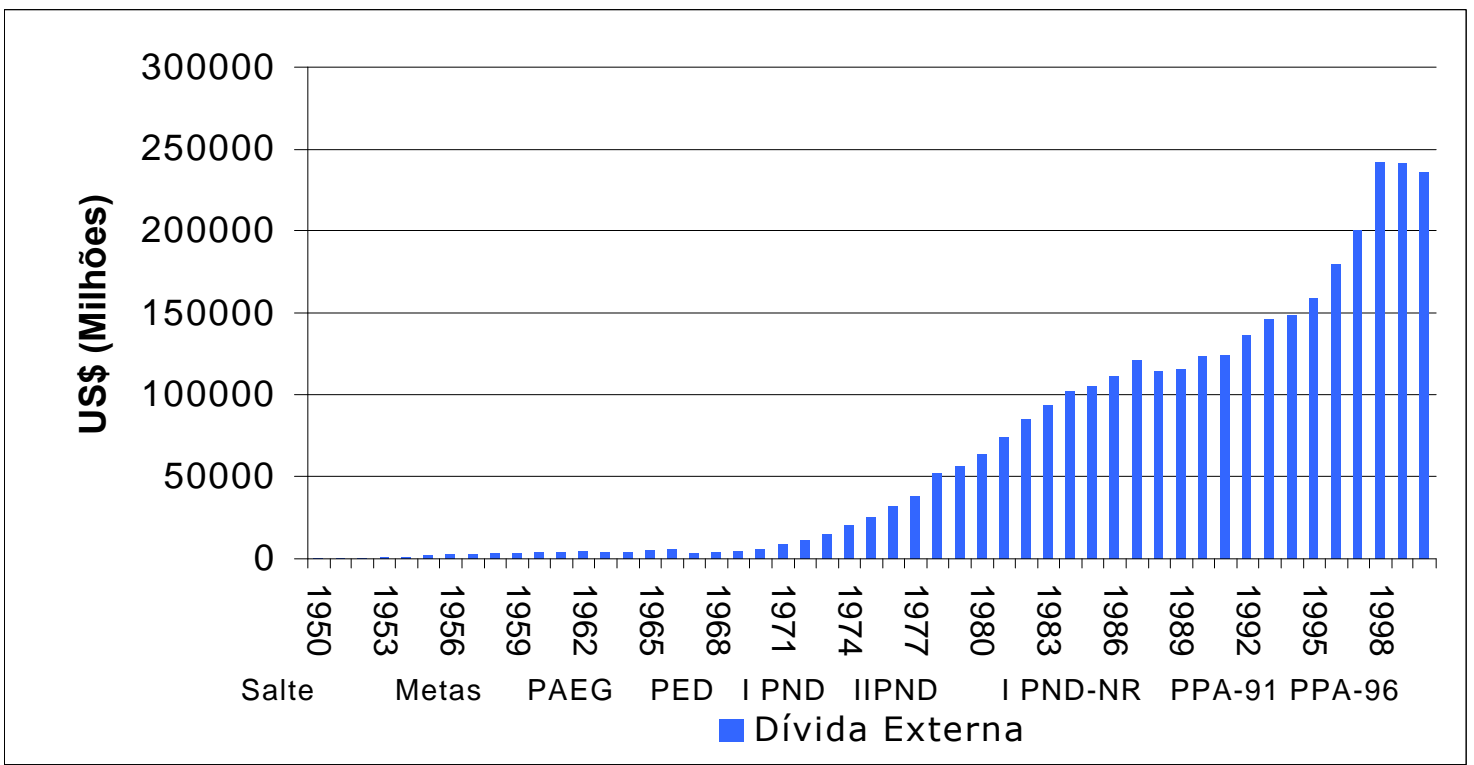

Figura 16 - Evolução da dívida externa bruta.

Fonte: IPEA (2002)

Tabela 29. Planos de desenvolvimento e dívida externa.

\begin{tabular}{lccc}
\hline Ano & Plano & Dívida Externa Bruta* & Média* \\
\hline 1950 & Plano Salte & 559 & 565 \\
1951 & & 571 & \\
1952 & & 638 & \\
1953 & & 1159 & \\
1954 & & 1317 & \\
1955 & & 1445 & \\
1956 & & 2694 & 3248,9 \\
1957 & & 2658 & \\
1958 & Plano de Metas & 3069 & \\
1959 & & 3392 & 3986 \\
1960 & & 3907 & \\
1961 & & 3773 & \\
1962 & & & \\
1963 & & 4025 & \\
1964 & Plano Trienal & 3986 & \\
1965 & & 3874 & \\
1966 & PAEG & 4758 & \\
1967 & & 5196 & \\
& & 3281 &
\end{tabular}


Tabela 29. Planos de desenvolvimento e dívida externa.

\begin{tabular}{|c|c|c|c|}
\hline Ano & Plano & Dívida Externa Bruta* & Média* \\
\hline $\begin{array}{l}1968 \\
1969 \\
1970\end{array}$ & PED & $\begin{array}{c}3780 \\
4403,5 \\
5295,2\end{array}$ & 4492,9 \\
\hline $\begin{array}{l}1971 \\
1972 \\
1973 \\
1974\end{array}$ & $\begin{array}{c}\text { Metas e Bases } \\
\text { I PND }\end{array}$ & $\begin{array}{c}8283,7 \\
11463,9 \\
14857,2 \\
20032,5\end{array}$ & 13659,31 \\
\hline $\begin{array}{l}1975 \\
1976 \\
1977 \\
1978 \\
1979\end{array}$ & II PND & $\begin{array}{l}25115,6 \\
32145,0 \\
37950,7 \\
52189,3 \\
55802,9\end{array}$ & 40640,73 \\
\hline $\begin{array}{l}1980 \\
1981 \\
1982 \\
1983 \\
1984 \\
1985\end{array}$ & III PND & $\begin{array}{c}64244,0 \\
73962,2 \\
85303,4 \\
93556,2 \\
102039,4 \\
105124,9\end{array}$ & 87371,69 \\
\hline $\begin{array}{l}1986 \\
1987 \\
1988 \\
1989 \\
1990\end{array}$ & I PND-NR/PAG & $\begin{array}{l}111044,4 \\
121173,7 \\
114435,1 \\
115506,1 \\
123438,5\end{array}$ & 117119,56 \\
\hline $\begin{array}{l}1991 \\
1992 \\
1993 \\
1994 \\
1995\end{array}$ & PPA-91 & $\begin{array}{l}123910,4 \\
135948,8 \\
145725,9 \\
148295,2 \\
159256,2\end{array}$ & 142627,3 \\
\hline $\begin{array}{l}1996 \\
1997 \\
1998 \\
1999\end{array}$ & PPA-96 & $\begin{array}{l}179935,0 \\
199998,0 \\
241644,0 \\
241467,9\end{array}$ & 215761, \\
\hline $\begin{array}{l}2000 \\
2001\end{array}$ & PPA-2000 & $\begin{array}{l}236156,6 \\
226067,2\end{array}$ & 225956 \\
\hline
\end{tabular}

Fonte: IPEA (2002)

* US\$ (milhões) 


\subsubsection{Dívida interna}

Em 1964, com o lançamento do PAEG, foi criado o mecanismo de captação de recursos via ORTN. Assim, a partir deste ano, tem-se o registro da dívida interna pública federal em títulos públicos. Observa-se que a dívida interna em títulos cresceu muito a partir do final dos anos 70 e que este crescimento está associado à crise da dívida externa. Isto porque a dívida externa foi quase toda estatizada e os seus encargos provocaram um profundo desequilíbrio no setor público brasileiro.

Desta forma, no final dos anos 70 e nos anos 80 , a poupança pública e o investimento público declinaram na mesma medida em que aumentaram os pagamentos com juros das dívidas externa e interna. A dívida interna teria crescido com a esterilização do excesso de moeda proveniente do ingresso de capitais externos no país, uma vez que os superávits comerciais presentes a partir de 1983, eram obtidos pelo setor privado, enquanto o responsável pelo pagamento da dívida externa era o setor público. Assim, a deterioração das contas internas do país avançava junto com a deterioração das contas externas.

Outras interpretações para a elevação da dívida interna consideram que esta pode ter sido ocasionada pelo crescimento dos encargos com pessoal e previdência e pelo excesso de despesas correntes, ou seja, pelo desequilíbrio fiscal. Outro fatores seriam o os gastos realizados durante o II PND e o crescimento do déficit das empresas estatais, uma vez que os investimentos relacionados à exploração de petróleo, 'a substituição de energia na indústria e no transporte, à substituição de importações de insumos básicos e nas atividades voltadas para a exportação prosseguiram e foram incluídos como prioridades no III PND, apesar dos anúncios de redução nos gastos públicos. Desta forma, até o final dos anos 70, a crise fiscal estava associada ao crescimento dos gastos com o financiamento interno, o que provocava um déficit primário. 
A partir dos anos 80 o crescimento da dívida interna está mais associado ao aumento da taxa de juros e àlimitação do uso da emissão monetária como mecanismo para financiar o déficit público. A elevação da taxa de juros aumentava os gastos com a remuneração dos títulos públicos, ao mesmo tempo em que estes se tornaram o principal mecanismo de financiamento do déficit. Além disto, na década de 80 houve uma gradual redução da credibilidade do governo quanto àsua capacidade de arcar com os juros e com a própria dívida interna. Este fato gerou uma redução contínua nos prazos de financiamento, atingindo um ponto em que a maior parte da dívida estava sendo financiada através do overnight com taxas reais de juros cada vez mais altas. Segundo Baer (1996), essas elevadas taxas de juros, associadas ao grande estoque da dívida aumentaram significativamente os gastos financeiros do governo, cuja parcela no total de gastos cresceu rapidamente, criando um círculo vicioso: dívida $\rightarrow$ déficit $\rightarrow$ dívida.

Como os planos de estabilização dos anos 80 não realizaram o necessário ajuste fiscal, as altas taxas de juros e a incerteza na qual a economia se encontrava agravaram o problema da dívida interna, provocando a queda dos investimentos, a estagnação econômica e aumentando a dificuldade de se colocar em prática os planos de desenvolvimento da época como o PAG e o I PNR-NR.

Para enfrentar os déficits orçamentários persistentes, o governo mantinha taxa de juros altas, elevando o custo da dívida pública. Em 1989, os gastos financeiros aumentaram $158 \%$ e foram a principal causa do déficit governamental.

Além disto, em 1988, a Nova Constituição provocou um impacto negativo sobre as finanças públicas do país ao aumentar as transferências de recursos fiscais do Governo Federal para os estados e municípios. Como a redução dos recursos do governo não foi acompanhada por uma diminuição em suas obrigações, a Constituição agravou o desequilíbrio estrutural do orçamento federal. 
Nos anos 90, as elevadas taxas de juros, usadas para atrair o capital estrangeiro e garantir o nível de reservas necessário para a estabilidade cambial, exerceram um impacto negativo sobre as finanças públicas. Esperava-se, contudo, que as privatizações reduziriam a dívida nãoliquidada do governo e assim, diminuiriam os gastos com os serviços da dívida, o que de fato, ocorreu no início dos anos 90. No entanto, a partir de 1995, a dívida interna voltou a aumentar e se manteve elevada.

Nos últimos anos, o país conseguiu obter superávits primários após realizar cortes no orçamento federal, o que revela que os gastos públicos com juros têm constituído a principal fonte de manutenção e geração do déficit público, comprometendo os gastos com programas governamentais do PPA.

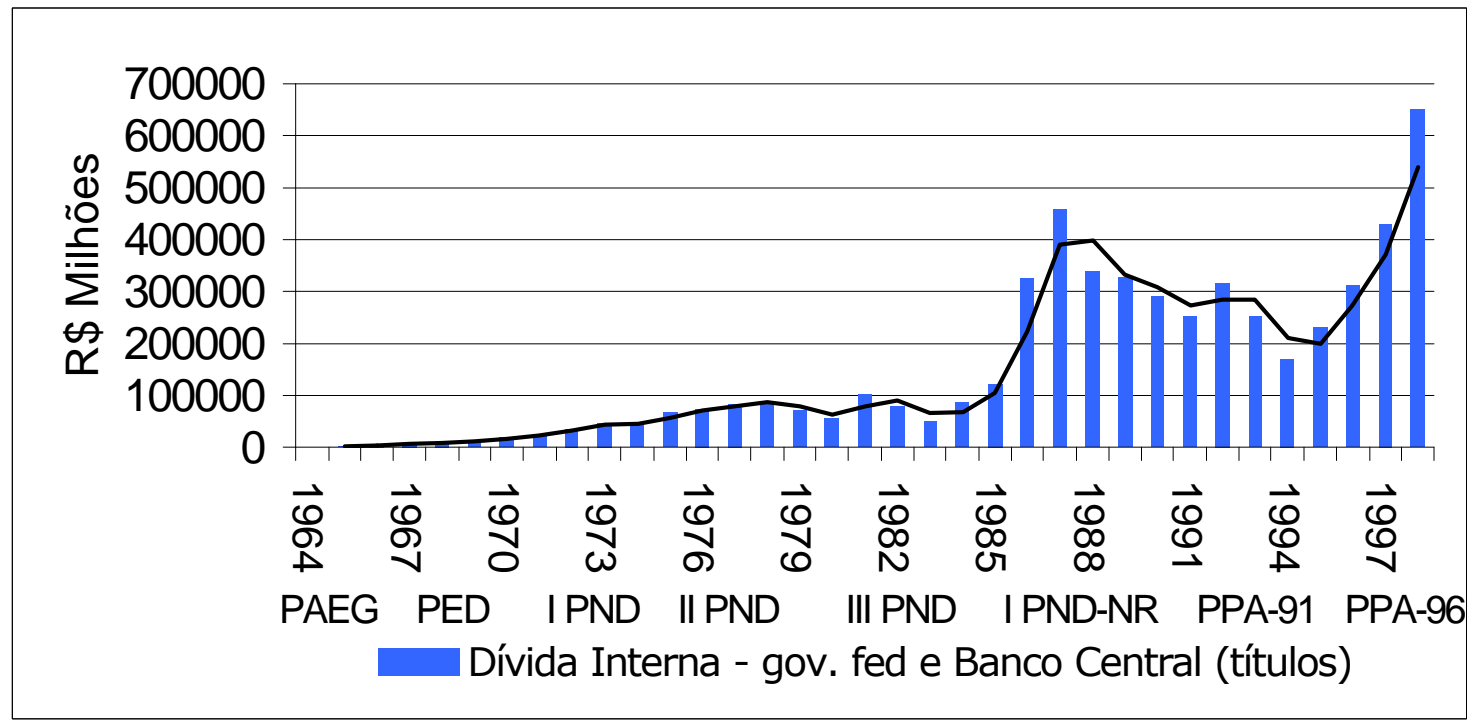

Figura 17 - Dívida interna em títulos 1964 - 1998.

Fonte: IPEA (2002) 


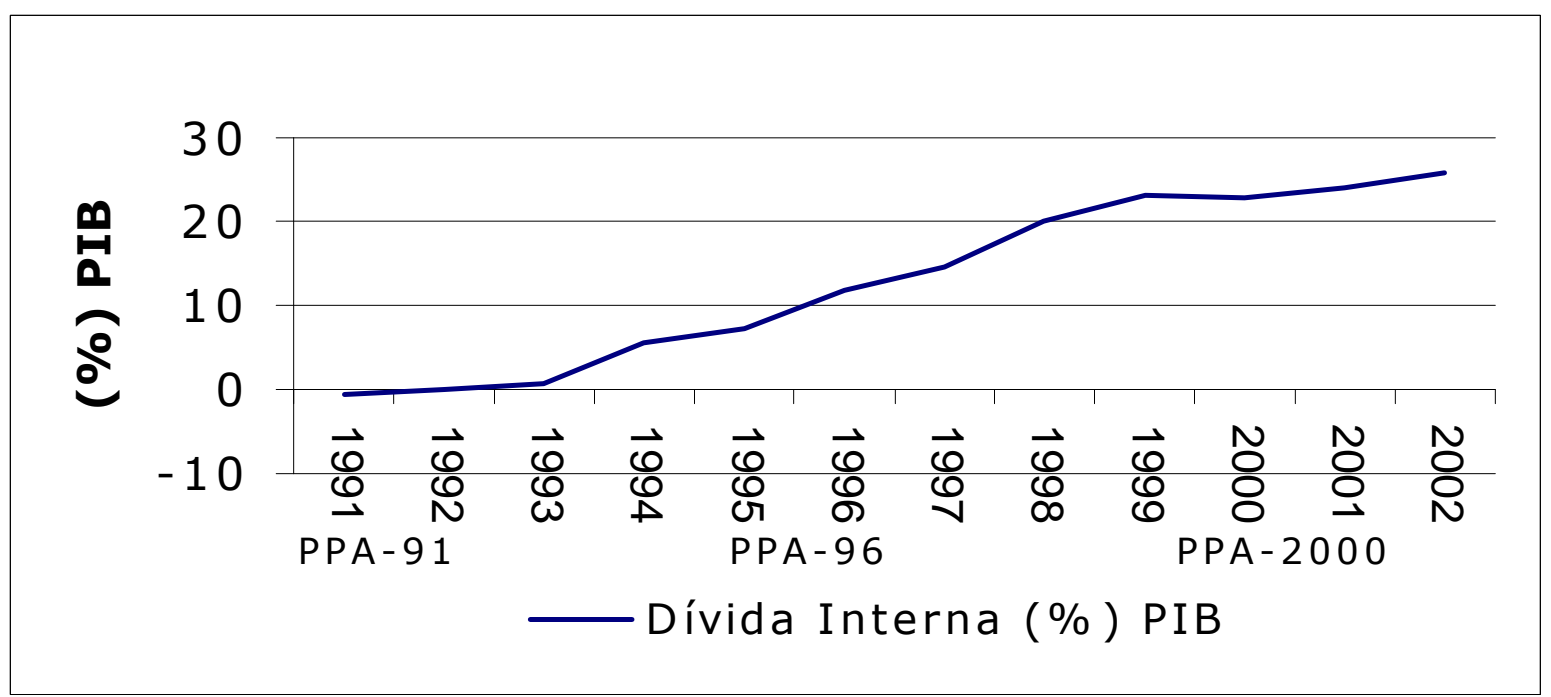

Figura 18 - Dívida interna como \% PIB (1991-2002).

Fonte: IPEA (2002)

Tabela 30. Planos de desenvolvimento e dívida interna.

\begin{tabular}{|c|c|c|c|}
\hline Ano & Plano & $\begin{array}{l}\text { Dívida Interna } \\
\text { (R\$ Milhões) }^{1}\end{array}$ & $\begin{array}{c}\text { Dívida Interna } \\
(\% \mathrm{PIB})^{2}\end{array}$ \\
\hline $\begin{array}{l}1964 \\
1965 \\
1966 \\
1967\end{array}$ & PAEG & $\begin{array}{c}332,2 \\
2560,8 \\
6089,0 \\
8677,5\end{array}$ & \\
\hline $\begin{array}{l}1968 \\
1969 \\
1970\end{array}$ & PED & $\begin{array}{c}9802,2 \\
13870,6 \\
19960,4\end{array}$ & \\
\hline $\begin{array}{l}1971 \\
1972 \\
1973 \\
1974\end{array}$ & $\begin{array}{c}\text { Metas e Bases } \\
\text { I PND }\end{array}$ & $\begin{array}{l}25515,1 \\
37375,0 \\
47080,8 \\
43743,4\end{array}$ & \\
\hline $\begin{array}{l}1975 \\
1976 \\
1977 \\
1978 \\
1979\end{array}$ & II PND & $\begin{array}{l}68742,7 \\
73902,9 \\
83668,3 \\
87945,1 \\
71447,3\end{array}$ & \\
\hline
\end{tabular}


Tabela 30. Planos de desenvolvimento e dívida interna.

\begin{tabular}{|c|c|c|c|}
\hline Ano & Plano & $\begin{array}{l}\text { Dívida Interna } \\
\text { (R\$ Milhões) }^{1}\end{array}$ & $\begin{array}{c}\text { Dívida Interna } \\
(\% \mathrm{PIB})^{2}\end{array}$ \\
\hline $\begin{array}{l}1980 \\
1981 \\
1982 \\
1983 \\
1984 \\
1985\end{array}$ & III PND & $\begin{array}{c}55194,1 \\
103129,6 \\
80382,1 \\
50461,3 \\
85682,3 \\
121741,6\end{array}$ & \\
\hline $\begin{array}{l}1986 \\
1987 \\
1988 \\
1989 \\
1990\end{array}$ & I PND-NR/PAG & $\begin{array}{l}323887,7 \\
455856,1 \\
337938,4 \\
327800,1 \\
291073,9\end{array}$ & \\
\hline $\begin{array}{l}1991 \\
1992 \\
1993 \\
1994 \\
1995\end{array}$ & PPA-91 & $\begin{array}{l}253037,6 \\
317042,5 \\
251804,8 \\
170106,5 \\
230986,1\end{array}$ & $\begin{array}{l}-0,7 \\
0,04 \\
0,66 \\
5,61 \\
7,30\end{array}$ \\
\hline $\begin{array}{l}1996 \\
1997 \\
1998\end{array}$ & PPA-96 & $\begin{array}{l}312439,1 \\
428921,9 \\
649244,4\end{array}$ & $\begin{array}{l}11,82 \\
14,57 \\
20,04\end{array}$ \\
\hline 1999 & & & 23,07 \\
\hline $\begin{array}{l}2000 \\
2001 \\
2002\end{array}$ & PPA-2000 & & $\begin{array}{l}22,86 \\
23,98 \\
25,85\end{array}$ \\
\hline
\end{tabular}

Fonte: IPEA (2002)

Dívida interna ${ }^{1}$ - pública - gov. federal e Banco Central - títulos (deflator: IGP-DI)

Dívida interna ${ }^{2}$ - líquida - gov. federal e Banco Central (como \% do PIB).

\subsubsection{A carga tributária}

Nos anos 50 o papel do Estado na economia se expandiu com o aprofundamento do planejamento para o desenvolvimento de setores específicos. Os formuladores da política econômica passaram a considerar que o sucesso dos planos dependia de iniciativas governamentais nos diversos campos. Assim, desde 1947, quando teve início o registro das 
contas nacionais do país, a carga tributária brasileira tem mostrado uma tendência ascendente, como conseqüência da evolução dos gastos públicos nos diversos setores.

No período de implementação dos planos Salte e de Metas o crescimento da carga tributária foi lento. Mas, a partir da reforma tributária realizada pelo PAEG houve uma mudança para um patamar bem mais alto (de $17 \%$ do PIB em 1964 para 24,9\% em 1969).

Durante os anos 70 e início dos anos 80 , a carga tributária mantevese no patamar dos 25\%, crescendo nos anos de 1982 e 1983 . Nos anos seguintes houve uma queda provavelmente causada pela recessão e pelo impacto da aceleração da inflação sobre o valor real dos impostos recolhidos. Contudo, de um modo geral, houve uma tendência contínua de crescimento da carga tributária e um aumento da importância do governo federal como agente coletor de impostos que chegou a recolher mais de $64 \%$ de todos os impostos (Araújo, 2001).

A reforma tributária realizada no país em 1988 pressionou gastos públicos, ao mesmo tempo em que provocou um aumento da carga tributária global e sobre vendas internas de bens e serviços, especialmente via tributos cumulativos. No entanto, a Constituição de 1988, reduziu as fontes de receita do Governo Federal aumentando substancialmente as transferências obrigatórias de recursos fiscais aos governos estaduais e municipais.

Outro salto na carga tributária foi registrado no período de 1994/2000. A explicação para este fato está no ajuste fiscal que precedeu o Plano Real, elevando os impostos, e na intensificação da utilização de tributos incidentes sobre bens e serviços. A carga tributária global passou ao patamar de cerca de 30\% do PIB. Em 2000 atingiu o nível de 32,6\% do PIB e o máximo histórico foi registrado em maio de 2002 com a carga de $35,4 \%$ do PIB.

Segundo Baer (1996), embora a carga tributária brasileira tenha aumentado esta ainda se encontra abaixo da carga apresentada por países 
industrializados, cuja média é de $36 \%$ do PIB. Ela é, contudo, elevada com relação aos países menos desenvolvidos que apresentam uma carga tributária de aproximadamente $16 \%$.

O governo brasileiro exerce uma importante influência sobre a distribuição de renda e a alocação de recursos pelo sistema fiscal. Durante o período em que prevaleceu o planejamento desenvolvimentista, em 1969 por exemplo, mais de $36 \%$ dos gastos públicos foram destinados a programas de previdência social e educação e quase $17 \%$ foram reservados à infra-estrutura. Já em 1990, a parcela destinada a programas de previdência social e educação havia caído para $30 \%$ do total dos gastos (Baer, 1996). Assim, embora a carga tributária tenha aumentado, houve uma diminuição dos gastos públicos com investimento e nas áreas sociais e um aumento do volume de gastos com pagamento de juros.

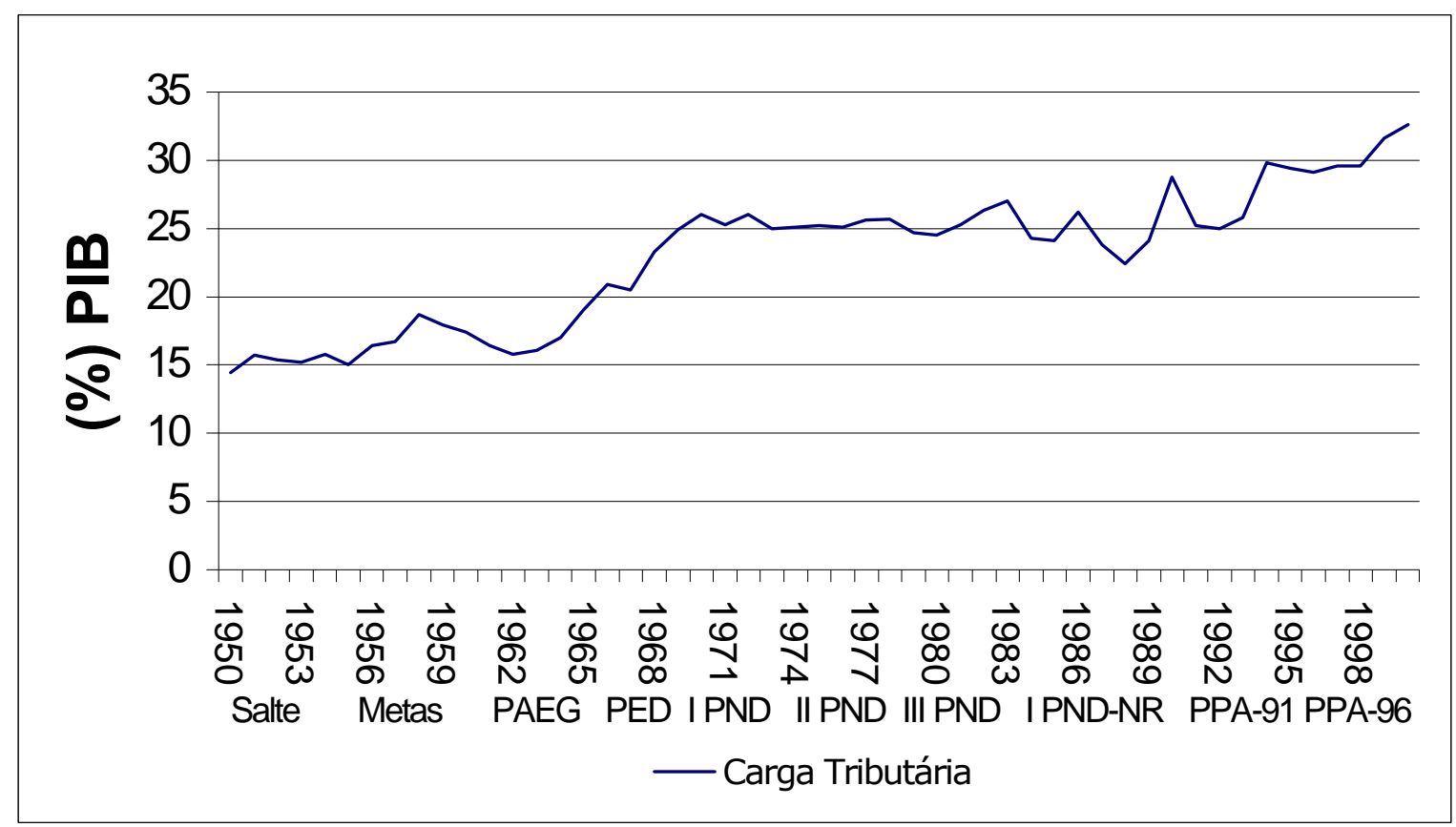

Figura 19 - Evolução da carga tributária 1950 - 2000.

Fontes: Varsano et al. (1998) e IPEA (2002) 
Tabela 31. Planos de desenvolvimento e carga tributária.

\begin{tabular}{|c|c|c|c|}
\hline Ano & Plano & Carga Tributária* & Média \\
\hline $\begin{array}{l}1950 \\
1951\end{array}$ & Plano Salte & $\begin{array}{l}14,4 \\
15,7\end{array}$ & 15,0 \\
\hline $\begin{array}{l}1952 \\
1953 \\
1954 \\
1955\end{array}$ & & $\begin{array}{c}15,4 \\
15,2 \\
15,8 \\
15\end{array}$ & \\
\hline $\begin{array}{l}1956 \\
1957 \\
1958 \\
1959 \\
1960 \\
1961\end{array}$ & Plano de Metas & $\begin{array}{l}16,4 \\
16,7 \\
18,7 \\
17,9 \\
17,4 \\
16,4\end{array}$ & 17,2 \\
\hline $\begin{array}{l}1962 \\
1963\end{array}$ & Plano Trienal & $\begin{array}{l}15,8 \\
16,1\end{array}$ & 16,1 \\
\hline $\begin{array}{l}1964 \\
1965 \\
1966 \\
1967\end{array}$ & PAEG & $\begin{array}{c}17 \\
19 \\
20,9 \\
20,5\end{array}$ & 19,3 \\
\hline $\begin{array}{l}1968 \\
1969 \\
1970\end{array}$ & PED & $\begin{array}{c}23,3 \\
24,9 \\
26\end{array}$ & 24,7 \\
\hline $\begin{array}{l}1971 \\
1972 \\
1973 \\
1974\end{array}$ & $\begin{array}{l}\text { Metas e Bases } \\
\text { I PND }\end{array}$ & $\begin{array}{c}25,3 \\
26 \\
25 \\
25,1\end{array}$ & 25,3 \\
\hline $\begin{array}{l}1975 \\
1976 \\
1977 \\
1978 \\
1979\end{array}$ & II PND & $\begin{array}{l}25,2 \\
25,1 \\
25,6 \\
25,7 \\
24,7\end{array}$ & 25,3 \\
\hline $\begin{array}{l}1980 \\
1981 \\
1982 \\
1983 \\
1984 \\
1985\end{array}$ & III PND & $\begin{array}{c}24,5 \\
25,3 \\
26,3 \\
27 \\
24,3 \\
24,1\end{array}$ & 25,2 \\
\hline $\begin{array}{l}1986 \\
1987 \\
1988 \\
1989 \\
1990\end{array}$ & I PND-NR/PAG & $\begin{array}{l}26,2 \\
23,8 \\
22,4 \\
24,1 \\
28,8\end{array}$ & 25,0 \\
\hline
\end{tabular}


Tabela 31. Planos de desenvolvimento e carga tributária.

\begin{tabular}{lccc}
\hline Ano & Plano & Carga Tributária* & Média \\
\hline 1991 & & 25,2 & \\
1992 & & 25 & \\
1993 & PPA-91 & 25,8 & 27,0 \\
1994 & & 29,8 & \\
1995 & & 29,4 & \\
1996 & & 29,1 & \\
1997 & PPA-96 & 29,6 & 29,9 \\
1998 & & 29,6 & \\
1999 & & 31,6 & 32,6 \\
2000 & PPA-2000 & 32,6 & \\
\hline
\end{tabular}

Fontes: Varsano et al. (1998) e IPEA (2002)

Carga tributária* - Volume total de impostos como \% do PIB.

\subsubsection{Indicadores sociais}

\subsubsection{Salário mínimo e distribuição de renda}

A melhoria das condições de vida da população constitui o objetivo final e sentido maior da política de desenvolvimento. Assim, nos planos de desenvolvimento elaborados no país, o ganho de valor real nos salários e a melhoria do Índice de Gini normalmente são considerados metas importantes.

O salário mínimo teve um salto durante o período de implementação do Plano de Metas refletindo a fase de crescimento da produção e de maior demanda por mão-de-obra. Posteriormente, a aceleração da inflação do início dos anos 60, assim como as medidas recessivas do Plano Trienal e do PAEG, geraram uma queda do valor real do salário mínimo no período.

O valor real do salário mínimo continuou em queda, mesmo com a economia em fase de expansão e com a inflação relativamente estabilizada. 
Durante o período que compreende o chamado Milagre Brasileiro, no qual foram implementados os planos PED, Metas e Bases e O I PND o salário mínimo real caiu $5,65 \%$. Os dados sobre a evolução do salário mínimo são bastante representativos da situação dos assalariados deste período uma vez que, em 1972, mais da metade dos assalariados brasileiros recebia até um salário mínimo e 75,3\% dos assalariados recebiam até dois salários mínimos. Assim, o crescimento econômico da época foi acompanhado de um aumento na concentração de renda que era defendida com o argumento de que esta incentivaria a formação de poupança e o aumento na taxa de investimento.

Desta forma, ainda que os planos de desenvolvimento deste período apresentassem a distribuição de renda como um de seus objetivos, a política de compressão salarial foi utilizada como mecanismo de elevação das taxas de lucro e de incentivo ao investimento.

Nos anos 80 (III PND, I PND-NR e PAG), o valor real do salário mínimo manteve-se em queda, com exceção para os anos de 1985 e 1986. Os motivos normalmente apontados para esta desvalorização são a inflação, com correções salariais defasadas, e a estagnação econômica.

No início dos anos 90, a tendência de queda se mantém, mas tem início uma recuperação do valor do salário mínimo a partir de 1994, dada a redução da inflação. A estabilidade inflacionária contribuiu para ampliação do mercado consumidor uma vez que permitiu, nos primeiros anos do Plano Real, um ganho concreto para as faixas mais baixas da população (as que mais perdiam no processo inflacionário).

Desta forma, a estabilidade é também apontada como fator responsável por um impacto positivo na distribuição de renda, embora a variação do Índice de Gini não mostre mudanças significativas ao longo dos anos 80 e 90 .

O Índice de Gini mede o grau de concentração de renda no país. 0 valor do índice varia entre 0 e 1 , sendo que, quanto mais próximo de 1 , maior o grau de concentração de renda. Em 1989 o índice apontou o maior 
nível de concentração de renda desde 1977 com valor próximo a 0,64 e, a partir de 1993, se retraiu estabilizando-se em torno de 0,60.

Embora esta seja uma variação pequena, a melhoria no índice pode ser atribuída à estabilização e também à abertura comercial dos anos 90 e sua conseqüente ampliação de mercado. Segundo Barros e Goldenstein (1997), a abertura provoca uma transferência de renda para o consumidor, correspondente ì tarifas que deixaram de ser pagas ao governo, àquase renda que os empresários obtinham com a reserva de mercado e aos ganhos de eficiência que necessariamente ocorrem na economia.

Assim, observa-se que os objetivos de valorização do salário e de redução das desigualdades de renda continuam fazendo parte dos programas de desenvolvimento, embora a forma de realização desta política tenha se modificado. No PPA-96 e no PPA-2000 esta nova política é agora entendida como a estabilização da economia e a abertura comercial, contrastando-se com a política dos anos 50, 60 e 70 que contava com um controle maior do Estado sobre o setor produtivo e sobre os salários.

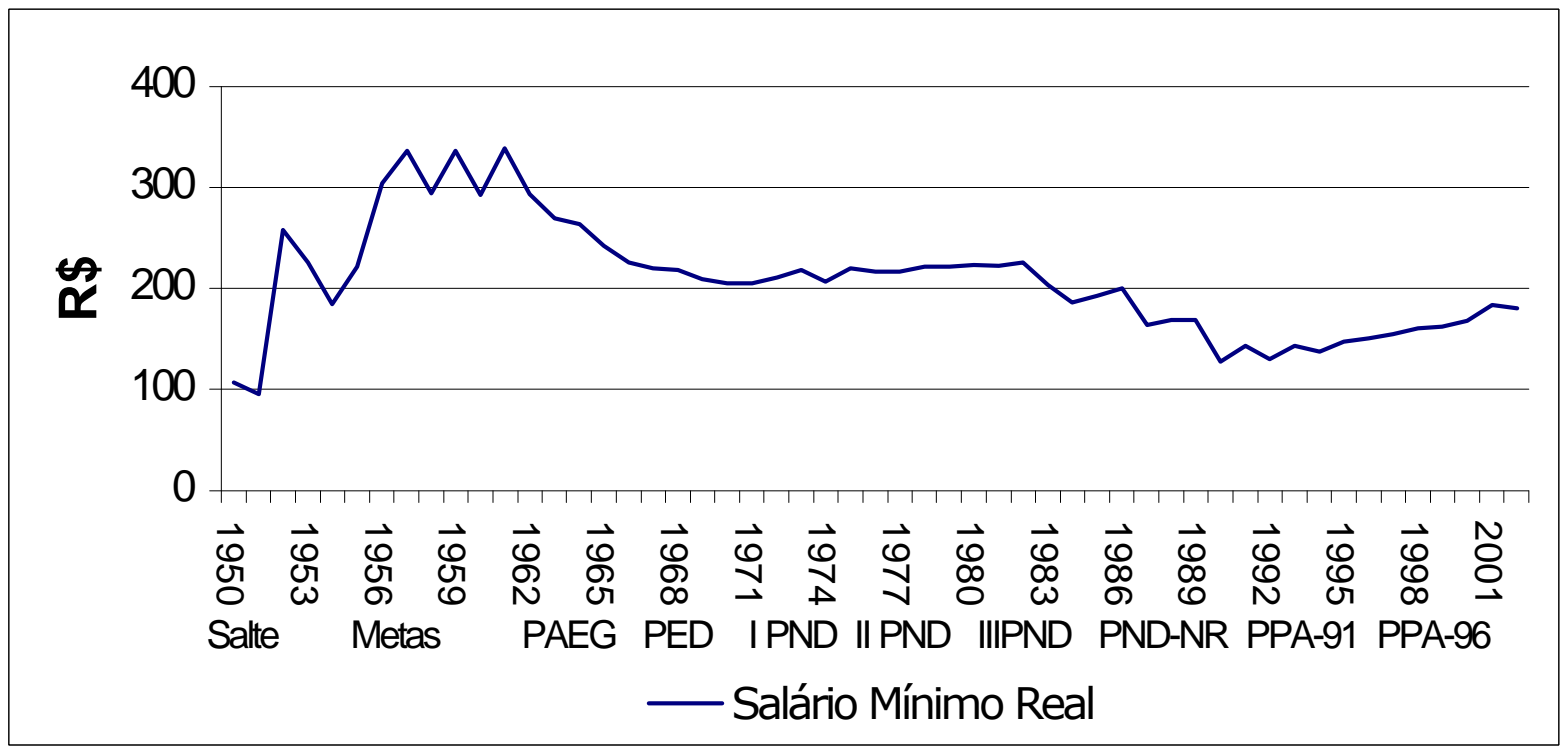

Figura 20 - Evolução do salário mínimo real 1950 - 2002.

Fonte: IPEA (2002) 


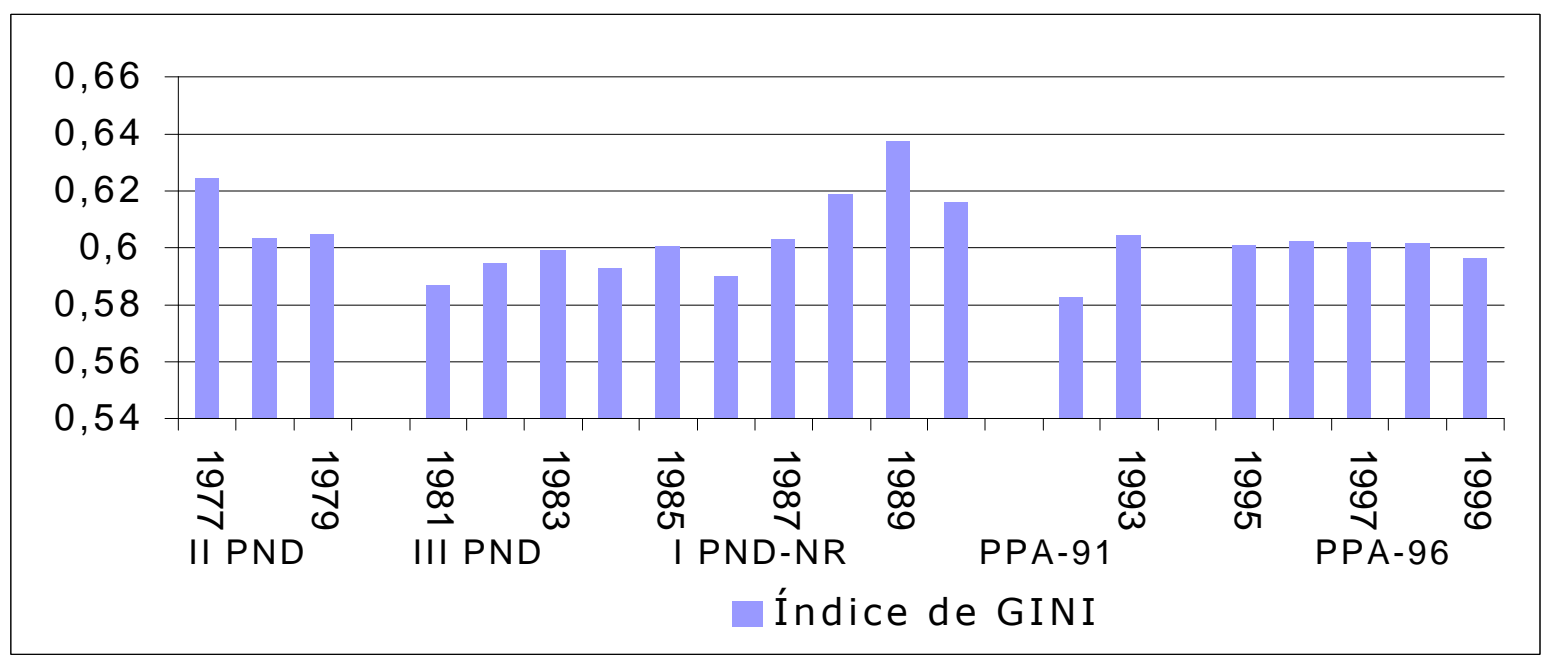

Figura 21 - Índice de GINI 1977 - 1999.

Fonte: IPEA (2002)

Tabela 32. Planos de desenvolvimento e a evolução do salário mínimo

\begin{tabular}{cccc}
\hline Ano & Plano & Salário Mínimo Real* & Variação (\%) \\
\hline 1950 & Plano Salte & 107,1 & $-10,7$ \\
1951 & & 95,6 & \\
1952 & & 257,5 & \\
1953 & & 225,3 & $-14,0$ \\
1954 & & 184,4 & \\
1955 & & 221,2 & \\
1956 & & 304,0 & \\
1957 & Plano de Metas & 336,6 & 11,36 \\
1958 & & 293,6 & \\
1959 & & 336,6 & \\
1960 & & 293,0 & \\
1961 & & 338,5 & $-8,08$ \\
1962 & & 293,2 & \\
1963 & & 269,5 & \\
1964 & Plano Trienal & 264,1 & $-16,8$ \\
1965 & & 242,2 & \\
1966 & PAEG & 225,1 &
\end{tabular}


Tabela 32. Planos de desenvolvimento e a evolução do salário mínimo

\begin{tabular}{|c|c|c|c|}
\hline Ano & Plano & Salário Mínimo Real* & Variação (\%) \\
\hline $\begin{array}{l}1968 \\
1969 \\
1970\end{array}$ & PED & $\begin{array}{l}218,7 \\
208,9 \\
205,0\end{array}$ & $-6,25$ \\
\hline $\begin{array}{l}1971 \\
1972 \\
1973 \\
1974\end{array}$ & $\begin{array}{c}\text { Metas e Bases } \\
\text { I PND }\end{array}$ & $\begin{array}{l}205,2 \\
210,5 \\
218,6 \\
206,3\end{array}$ & 0,53 \\
\hline $\begin{array}{l}1975 \\
1976 \\
1977 \\
1978 \\
1979\end{array}$ & II PND & $\begin{array}{l}220,2 \\
216,2 \\
216,7 \\
221,7 \\
221,2\end{array}$ & 0,44 \\
\hline $\begin{array}{l}1980 \\
1981 \\
1982 \\
1983 \\
1984 \\
1985\end{array}$ & III PND & $\begin{array}{l}223,2 \\
222,4 \\
225,4 \\
203,5 \\
185,9 \\
192,9\end{array}$ & $-13,5$ \\
\hline $\begin{array}{l}1986 \\
1987 \\
1988 \\
1989 \\
1990\end{array}$ & I PND-NR/PAG & $\begin{array}{l}199,6 \\
163,3 \\
169,0 \\
169,0 \\
126,9\end{array}$ & $-36,4$ \\
\hline $\begin{array}{l}1991 \\
1992 \\
1993 \\
1994 \\
1995\end{array}$ & PPA-91 & $\begin{array}{l}143,2 \\
130,0 \\
143,4 \\
137,5 \\
146,7\end{array}$ & 2,48 \\
\hline $\begin{array}{l}1996 \\
1997 \\
1998 \\
1999\end{array}$ & PPA-96 & $\begin{array}{l}150,7 \\
154,5 \\
160,8 \\
162,2\end{array}$ & 7,64 \\
\hline $\begin{array}{l}2000 \\
2001 \\
2002\end{array}$ & PPA-2000 & $\begin{array}{l}167,8 \\
183,0 \\
180,3\end{array}$ & 7,43 \\
\hline
\end{tabular}

Fonte: IPEA (2002)

*Deflacionado com base no ICV da FGV até 1979 e nos anos posteriores com base no INPC do IBGE (março de 1979). 
Tabela 33. Planos de desenvolvimento e distribuição de renda.

\begin{tabular}{llll}
\hline Ano & Plano & Índice de Gini & Média \\
\hline 1980 & & 0,587 & \\
1981 & & 0,594 & \\
1982 & III PND & 0,599 & 0,59 \\
1983 & & 0,593 & \\
1984 & & 0,601 & \\
1985 & & 0,590 & \\
1986 & & 0,603 & \\
1987 & & 0,619 & 0,61 \\
1988 & I PND-NR/PAG & 0,637 & \\
1989 & & 0,616 & \\
1990 & & & \\
1991 & & 0,583 & \\
1992 & & 0,604 & \\
1993 & PPA-91 & & \\
1994 & & 0,601 & \\
1995 & & 0,602 & \\
1996 & & 0,602 & \\
1997 & & 0,602 & \\
1998 & PPA-96 & 0,596 & \\
1999 & & & \\
2000 & PPA-2000 & & \\
\hline
\end{tabular}

Fonte: IPEA (2002)

\subsubsection{O Índice de Desenvolvimento Humano (IDH)}

Segundo o Programa das Nações Unidas para o Desenvolvimento (PNUD), o IDH é um indicador que busca captar e sintetizar as diversas e complexas dimensões do processo de desenvolvimento humano. Em sua metodologia, reconhece que três condições essenciais estão presentes em todos os níveis de desenvolvimento: desfrutar uma vida longa e saudável, 
adquirir conhecimento e ter acesso aos recursos necessários para um padrão de vida digno.

Assim, utiliza os seguintes indicadores: para medir a longevidade, a esperança de vida ao nascer; para o nível educacional, a taxa de alfabetização dos adultos combinada com a taxa de matrícula nos ensinos fundamental, médio e superior; e como indicador de acesso aos recursos, utiliza-se a renda per capita. O resultado do IDH varia entre 0 e 1 . Um IDH compreendido entre 0 a 0,5 indica baixo desenvolvimento humano, se estiver entre 0,5 e 0,8 considera-se que há desenvolvimento humano médio e de 0,8 a 1, verifica-se um alto desenvolvimento humano.

O Brasil tem situado-se na faixa característica de países de médio desenvolvimento humano, embora entre as regiões brasileiras haja heterogeneidade no índice. Em 1997 o país ocupava o 79ํlugar no ranking de classificação entre os 174 países analisados e, em 2000, ocupou o 73응 lugar.

Observando a evolução do IDH de $1970(0,494)$ para $1996(0,830)$ nota-se um considerável aumento no índice. Houve um maior crescimento do IDH durante os anos 70, refletindo a elevação da produção e da renda per capita durante o período de implementação dos planos PED, Metas e Bases, I PND e II PND. Já nos anos 80 , houve uma estagnação no índice e um novo crescimento a partir da década de 90.

Segundo o PNUD, a melhora no desenvolvimento humano da população brasileira decorreu também de um maior acesso ao conhecimento e da melhoria no índice de esperança de vida.

A partir de 1998 houve uma mudança na metodologia de cálculo do IDH realizada com o objetivo de captar a concentração de renda presente no indicador da renda per capita. Com a mudança, o IDH apresentou uma queda, embora seu valor em 1998, de 0,749, continue bastante acima do observado em $1970(0,494)$. 


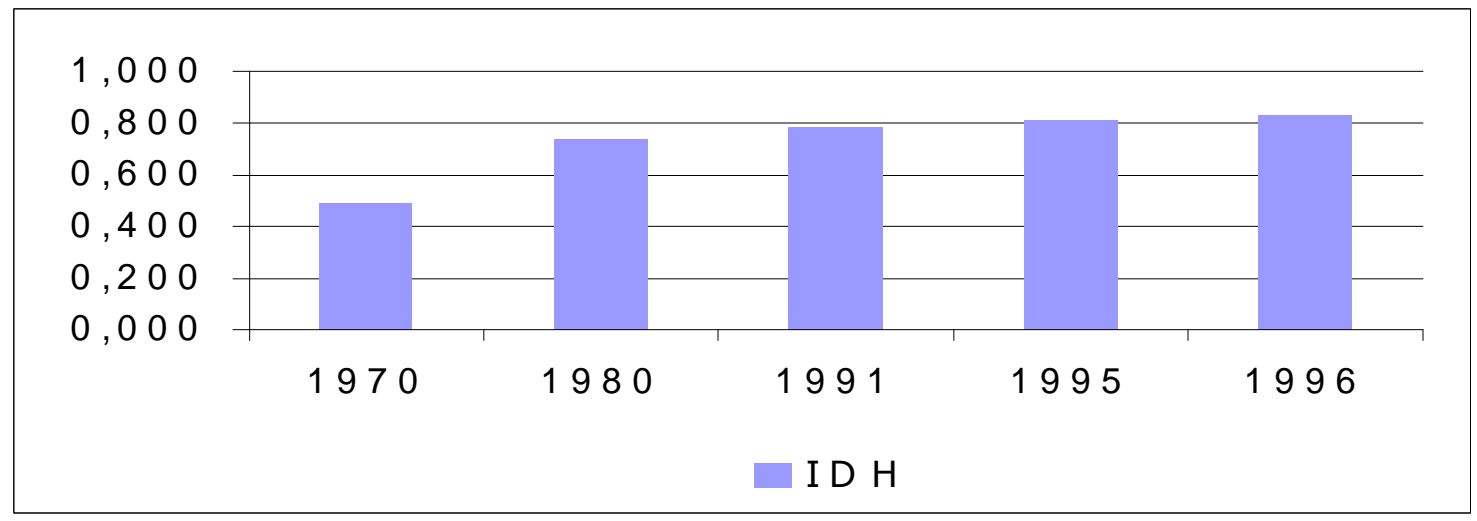

Figura 22 - Índice de Desenvolvimento Humano 1970-1996.

Fonte: PNUD (1998)

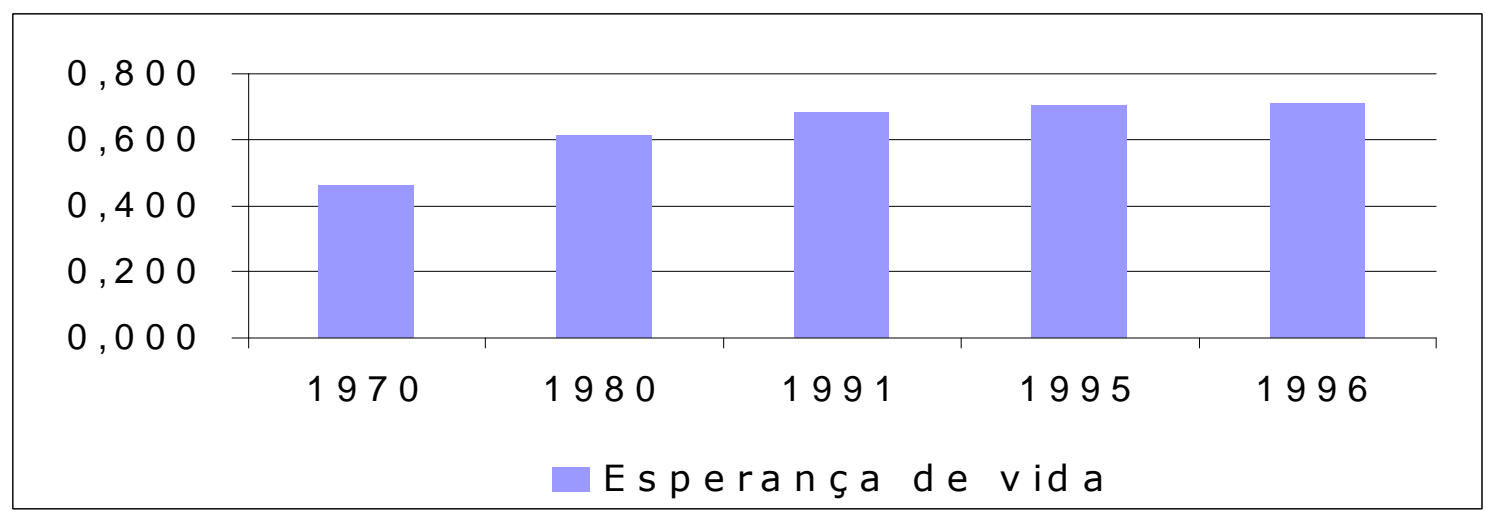

Figura 23 - Índice de esperança de vida.

Fonte: PNUD (1998)

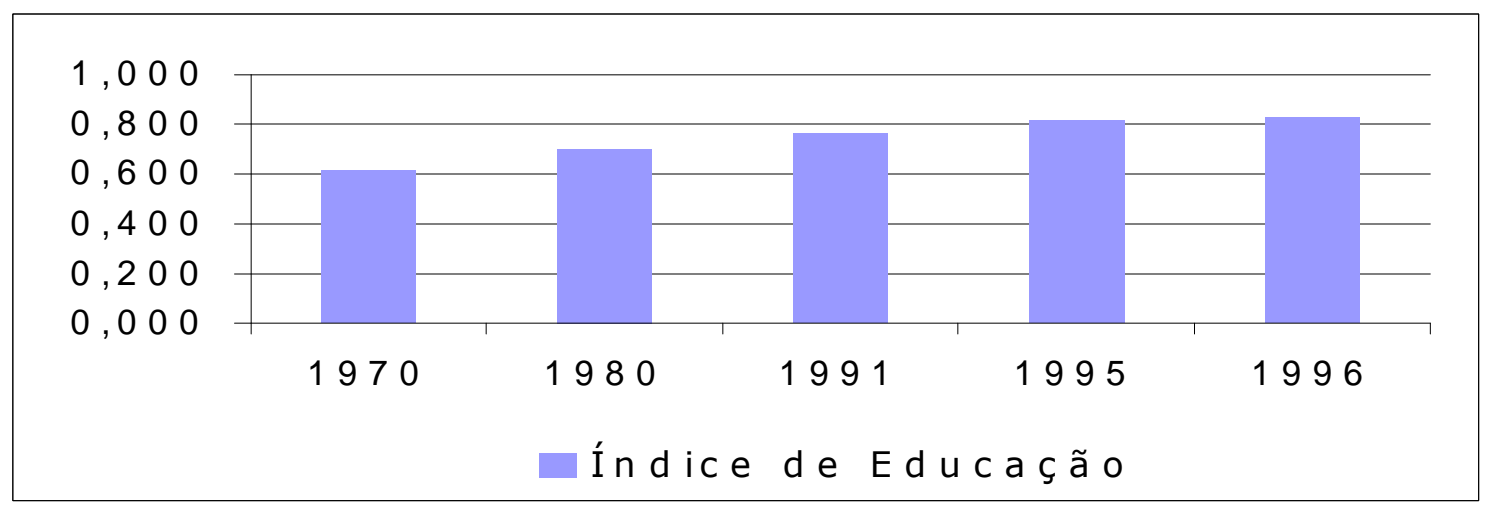

Figura 24 - Índice de educação.

Fonte: PNUD (1998) 
Tabela 34. Indicadores sociais $1970-2000$.

\begin{tabular}{|c|c|c|c|}
\hline Ano & IDH & Educação $^{1}$ & $\begin{array}{c}\text { Esperança de } \\
\text { vida }^{2}\end{array}$ \\
\hline 1970 & 0,49 & 0,61 & 0,46 \\
\hline 1980 & 0,73 & 0,70 & 0,61 \\
\hline 1991 & 0,79 & 0,76 & 0,69 \\
\hline 1995 & 0,81 & 0,81 & 0,70 \\
\hline 1996 & 0,83 & 0,82 & 0,71 \\
\hline 1997 & $0,739 *$ & & \\
\hline 1998 & $0,749 *$ & & \\
\hline 2000 & $0,757 *$ & & \\
\hline
\end{tabular}

Fonte: PNUD - Relatório de Desenvolvimento Humano (1998), (2000) e (2002)

* valor obtido após mudança na metodologia de cálculo do IDH.

${ }^{1}$ Taxa de alfabetização de adultos e taxa de escolaridade bruta combinada.

2 Realização relativa de um país na esperança de vida ànascença.

\subsubsection{Indicador de pobreza}

Como indicador do nível de pobreza do país, a presente pesquisa considerou o número de pessoas abaixo da linha de indigência, que corresponde àsituação na qual o indivídu o é destituído de uma remuneração que lhe garanta condições mínimas de sobrevivência.

A diminuição da pobreza foi considerada um dos objetivos centrais da política de desenvolvimento realizada no país ao longo dos últimos 50 anos. No entanto, observa-se uma elevação no índice de pobreza a partir dos anos 70 e que se manteve durante a década de 80 , com exceção para o ano de 1986 como reflexo do Plano Cruzado. 
A manutenção de um número elevado de pessoas situando-se abaixo da linha de indigência revela a ineficácia da política de desenvolvimento realizada nas últimas décadas. Apesar disto, após 1993, houve uma redução do valor percentual de pessoas abaixo da linha de indigência com relação à população total de 19,5\% em 1993 para 14,5\% em 1999. Esta mudança no índice indica uma possível relação entre a redução da taxa de inflação a partir de 1994 e a redução da pobreza no país.

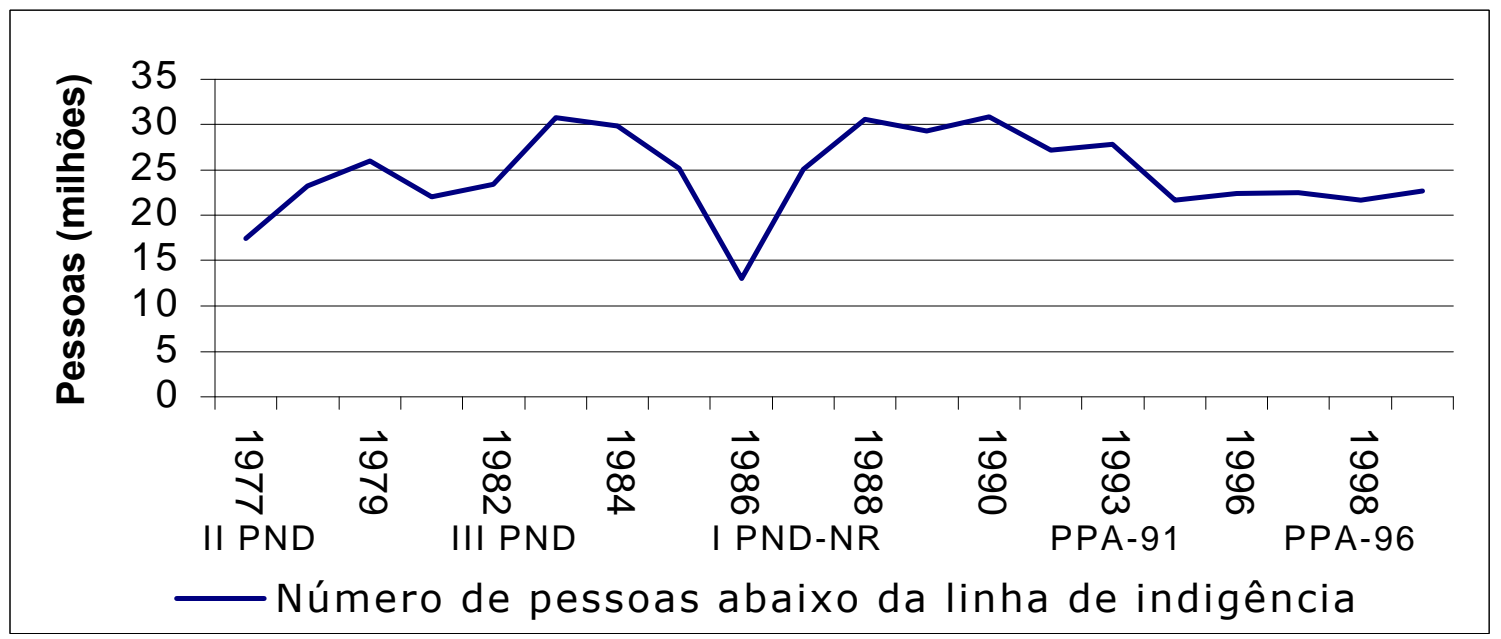

Figura 25 - Índice de pobreza 1977 - 1999.

Fonte: IPEA (2002) 
Tabela 35. Planos de desenvolvimento e índice de pobreza.

\begin{tabular}{ccccc}
\hline Ano & Plano & $\begin{array}{c}\text { Número de } \\
\text { pessoas abaixo } \\
\text { da linha da } \\
\text { indigência* }\end{array}$ & Média* & $\begin{array}{c}\text { (\%) de pessoas } \\
\text { abaixo da linha de } \\
\text { indigência na } \\
\text { população total }\end{array}$ \\
\hline 1977 & II PND & 17,4 & 23,2 & 21,8 \\
1978 & & 23,2 & & 23,9 \\
1979 & & 25,9 & & \\
1981 & & 22,0 & & 18,8 \\
1982 & & 23,4 & 25,1 & 19,4 \\
1983 & III PND & 30,7 & & 24,9 \\
1984 & & 29,8 & & 23,6 \\
1985 & & 25,1 & & 19,2 \\
1986 & & 13,0 & & \\
1987 & & 25,0 & 29,9 & 18,8 \\
1988 & I PND-NR & 30,5 & & 22,1 \\
1989 & PAG & 29,3 & & 20,7 \\
1990 & & 30,8 & & 21,3 \\
1992 & & 27,1 & & 19,3 \\
1993 & PPA-91 & 27,8 & 27,1 & 19,5 \\
1995 & & 21,6 & & 14,6 \\
1996 & & 22,4 & & 14,9 \\
1997 & & 22,5 & 22,4 & 14,8 \\
1998 & PPA-96 & 21,6 & & 14,1 \\
1999 & & 22,6 & & 14,5 \\
\hline
\end{tabular}

Fonte: IPEA (2002)

* Pessoas (milhões). 


\section{CONCLUSÕES}

O presente trabalho buscou analisar a trajetória do planejamento para o desenvolvimento no Brasil. Para isso, dividiu-se em quatro etapas: primeiramente, foi realizada uma revisão bibliográfica sobre a evolução do planejamento no país até 1979, com a descrição dos planos até o II PND e da crise do planejamento a partir dos anos 80; na segunda e terceira parte, procurou-se identificar, descrever e analisar os planos de desenvolvimento elaborados no país após o II PND; e, por último, buscou-se observar a evolução de indicadores econômicos e sociais durante as fases de implementação dos planos de desenvolvimento.

$\mathrm{Na}$ primeira fase da pesquisa, foi constatado o crescimento da importância atribuída ao planejamento desde o Plano Salte até atingir o seu auge com a implementação do II PND. Houve um processo no qual gradativamente o planejamento foi assumindo as seguintes características: abrangência; institucionalização; compatibilidade com a economia de mercado; mínima participação de setores externos ao governo; importância maior do fator social; identidade de objetivos, com estratégias e diretrizes similares; prazos curtos e ausência de um plano de perspectivas (com a exceção do Plano Decenal) e a tendência ao abandono de metas rígidas, com o uso de indicadores básicos.

Como resultado do planejamento neste período, o Brasil pôde estruturar a sua cadeia produtiva e dar início àconstituição de indústrias de tecnologia mais avançada. O modelo de crescimento adotado, a substituição 
de importações, foi finalizado e o país obteve uma base industrial ampla e diversificada. A política adotada, na maioria das vezes, possibilitou o rápido crescimento do PIB e da produção industrial, mas definiu uma prática de política governamental que se esgotaria a partir dos anos 80 .

Até o II PND, o processo de planejamento ganhou experiência e refinamento na produção de planos, mas estes perderam credibilidade a partir da década de 80 . A crise que se instaurou no país nesta época se refletiu diretamente na capacidade de planejamento do setor público. Entre os fatores associados à crise do planejamento está a própria crise fiscal do Estado, a rejeição do planejamento econômico (dado o relativo insucesso do II PND) e a descrença na capacidade de planificação do governo.

$\mathrm{Na}$ segunda e terceira parte do trabalho, constatou-se que, no período que se iniciou com o III PND, e que perdurou durante praticamente toda a década de 90, prevaleceu a falência do planejamento no Brasil e um profundo descrédito quanto ao seu potencial.

Os planos de desenvolvimento da década de 80 , identificados pela pesquisa e anteriores ao mandato constitucional de 1988, obtiveram um grau de implementação muito baixo ou, até mesmo, nulo, evidenciando a descrença no planejamento público para o desenvolvimento e a própria incapacidade do governo de colocá-los em prática. Além disto, a preocupação central do governo foi deslocada do desenvolvimento para a estabilidade macroeconômica. Desta forma, ao se estudar o III PND, o I PND-NR e o PAG percebe-se claramente a pouca atenção dada a estes planos, que foram criados simplesmente para atender àConstituição.

Com a Nova Constituinte, ficou estabelecido o modelo de planejamento baseado nos planos plurianuais. No entanto, o primeiro PPA, o PPA-91, não pode ser considerado como um instrumento para estimular o desenvolvimento. Criado também apenas para cumprir o mandato constitucional, suas propostas se distanciaram em muito das verdadeiras intenções do governo e foi logo esquecido diante da crise política que o país enfrentou em 1992. 
A partir do segundo PPA, O PPA-96, percebe-se um esforço para a retomada do planejamento no âmbito da administração pública federal. Embora o processo apresente ainda sérios problemas, perece haver uma gradual recuperação da importância atribuída ao planejamento como instrumento da ação governamental. Faz-se até mesmo comparações entre os novos PPA's e o Plano de Metas de JK. Mas, evidentemente, essas comparações são controversas, dado que autores como Garcia (2000), consideram o PPA-96 como uma simples expansão de um orçamento plurianual de investimentos.

De qualquer forma, parece claro que a partir de 1996 há uma maior preocupação com o planejamento uma vez que, com um ambiente macroeconômico mais estável, o governo pôde voltar a sua atenção novamente para políticas de mais longo prazo.

Assim, os tópicos deste trabalho que analisam o PPA-96 e PPA-2000 são mais detalhados refletindo a crescente importância atribuída aos planos plurianuais. Do primeiro PPA, de 1991, ao Avança Brasil, de 2000, que usa o modelo de gerenciamento na execução dos programas, notam-se consideráveis progressos em termos de valorização do planejamento e de um esforço maior para o aprimoramento na implementação e no alcance de objetivos.

$\mathrm{Na}$ última parte do trabalho, observou-se a evolução de indicadores sócio-econômicos nas fases de implementação dos planos de desenvolvimento dos últimos 50 anos. A análise do capítulo 4 revela que a efetivação da política de desenvolvimento não só causa impactos sobre os indicadores selecionados, como também é afetada por eles.

Considerando os indicadores da produção, observa-se que as políticas explícitas de incentivo ao crescimento econômico, como as que estiveram presentes até o II PND, de fato conseguiram afetar positivamente o PIB, a renda per capita e a taxa de investimento.

Posteriormente, a implementação precária dos planos de desenvolvimento até o PPA-96, não permite maior associação entre estes e 
as modificações ocorridas nos indicadores da produção. Assim, o comportamento dos indicadores após 1980 parece se relacionar mais com as variações da política de curto prazo do que com a presença destes planos.

Quanto aos indicadores macroeconômicos como a taxa de inflação, a dívida externa e a dívida interna, observa-se que nos períodos em que estes índices atingiram níveis elevados, causando crises para o setor público e para a economia em geral, houve uma dificuldade maior em se efetivar políticas de desenvolvimento, dado que o governo passou a se concentrar no objetivo de estabilização macroeconômica. Sabe-se contudo, que a política de desenvolvimento não mais poderia atuar como nas décadas de 50, 60 e 70, pois não seria funcional ànova realidade que se impôs a partir dos anos 80.

Com relação aos indicadores sociais, constata-se que os planos de desenvolvimento implementados no país têm sido ineficazes no sentido de proporcionar uma melhoria nas condições de vida da população, principalmente nos que diz respeito à redução do desemprego e das desigualdades sociais. 


\section{REFERÊNCIAS BIBLIOGRÁFICAS}

AFFONSO, R. A ruptura do padrão de financiamento do setor público e a crise do planejamento no Brasil durante os anos 80. In: SEMINÁRIO SOBRE PLANEJAMENTO E GESTÃO, Brasília, 1989. Anais. Brasília: FUNCEP/IPEA/SEPLAN，1989, p.141-186.

AHUMADA, J. Teoria y programacion del desarrollo econômico: curso intensivo de treinamento em problemas de desenvolvimento. Rio de Janeiro: CEPAL/DOAT, 1960.

ARAÚJO, E. Carga tributária - evolução histórica: uma tendência crescente. Brasília: Secretaria para Assuntos Fiscais, jul. 2001. (Informe - SF, 29)

BAER, W. A economia brasileira. São Paulo: Nobel, 1996.

BARROS, J.R.M. de; GOLDENSTEIN, L. Avaliação do processo de reestruturação industrial brasileiro. Revista de Economia Política, v.17, n.2, p.11-31, abr. 1997.

BONELLI, R. Linhas gerais para a política industrial. O Brasil no fim do século: desafios e propostas para a ação governamental. Rio de Janeiro: IPEA, 1994, p.243-256: Estado Promotor - Políticas de Apoio ao Setor Produtivo. 
BRASIL. Comissão para o Plano de Governo. A política Industrial da Nova República. Brasília, 1985a.

BRASIL. Ministério do Planejamento, Orçamento e Gestão. O plano plurianual 1996-1999 (PPA 1996-1999). Brasília, 1995a.

BRASIL. Ministério do Planejamento, Orçamento e Gestão. O plano plurianual 2000-2003 (PPA 2000-2003). Brasília, 1999a.

BRASIL. Ministério do Planejamento, Orçamento e Gestão. Secretaria de Gestão. O plano plurianual Avança Brasil e o programa Gestão Pública Empreendedora. http://www.planejamento.gov.br (15 out. 2000)

BRASIL. Ministério do Planejamento, Orçamento e Gestão. Relatório Anual de Avaliação do Plano Plurianual 2000-2003 - Avança Brasil. http://www.planejamento.gov.br (18 out. 2001)

BRASIL. Ministério do Planejamento, Orçamento e Gestão. Relatório Anual de Avaliação do Plano Plurianual 2000-2003 - Avança Brasil. http://www.planejamento.gov.br (20 jul. 2002)

BRASIL. Presidência da República. Mensagem ao Congresso Nacional. Plano de Ação Governamental. Brasília, 1986.

BRASIL. Presidência da República. Metas e Bases para a Ação do Governo. Brasília, 1970.

BRASIL. Presidência da República. I Plano Nacional de Desenvolvimento, 1972-74. Rio de Janeiro, 1971. 
BRASIL. Presidência da República. I Plano Nacional de Desenvolvimento da Nova República - 1986/1989. Brasília, 1985b.

BRASIL. Secretaria do Tesouro Nacional (STN/SIAFI). Execução Orçamentária por Subprograma 1996, 1997 e 1998. Brasília, 1999b.

BRASIL. Senado Federal. Comissão Temporária de Obras Inacabadas. 0 retrato do desperdício no Brasil. Brasília, 1995b.

BRASIL. Senado Federal. Constituição da República Federativa do Brasil. Brasília, 1988.

BRESSER PEREIRA, L.C. Economia brasileira: uma introdução crítica. 3.ed. São Paulo: Editora 34, 1998.

CASTRO, A.B.; SOUZA, F.E.P. A economia brasileira em marcha forçada. Rio de Janeiro: Paz e Terra, 1985.

COMISSÃO ECONÔMICA PARA A AMÉRICA LATINA. Desarrollo econômico, planeamiento y cooperacion internacional. Caracas: CEPAL/DOAT, 1961.

CHENERY, H.B. Política y programas de desarrollo. Boletim Econômico da América Latina, v.3, n.1, p.12-43, jan. 1961.

FRITSCH, W. A política industrial do novo governo: um passo para frente e dois para trás? In: FARO, C. (Org.). Plano Collor: avaliações e perspectivas. Rio de Janeiro: Livros Técnicos e Científicos Editora, 1990. 
FURTADO, C. O Brasil pós-"milagre". Rio de Janeiro: Paz e Terra, 1981.

GARCIA, R.C. A reorganização do processo de planejamento do governo federal: O PPA 2000-2003. Brasília: IPEA, maio 2000. (Texto Para Discussão, 726)

GIACOMONI, J. Orçamento público. São Paulo: Atlas, 1996.

HOLANDA, N. Planejamento e projetos. Fortaleza: Edições UFC, 1983.

IANNI, O. Estado e planejamento econômico no Brasil, 1930-1970. Rio de Janeiro: Civilização Brasileira, 1971.

INSTITUTO DE PESQUISA ECONÔMICA APLICADA. A controvérsia do planejamento na economia brasileira: coletânea do debate entre Roberto Simonsen e Eugênio Gudin sobre o planejamento no final do Estado Novo. Rio de Janeiro: IPEA/INPES, 1977. (Série Pensamento Econômico Brasileiro)

INSTITUTO DE PESQUISA ECONÔMICA APLICADA. IPEADATA: base de dados macroeconômicos. http://www.ipeadata.gov.br (25 jul. 2002)

JAGUARIBE， $H$. Desenvolvimento econômico programado e organização política. Rio de Janeiro: CEPAL/DOAT, 1961.

KOHAMA, H. Contabilidade pública. São Paulo: Atlas, 1998.

LACERDA, A.C; BOCCHI, J.I.; REGO, M.J.; BORGES, M.A.; MARQUES, R.M. Economia brasileira. São Paulo: Saraiva, 2000.

LAFER, B.M. Planejamento no Brasil. São Paulo: Perspectiva, 1970. 
LESSA, C. Quinze anos de política econômica. São Paulo: Brasiliense, 1981.

LOPES, C.T.G. Planejamento, Estado e crescimento. São Paulo: Pioneira, 1990.

PEREIRA, M.J. Finanças públicas: a política orçamentária no Brasil. São Paulo: Atlas, 1998.

PINTO, A. Financiamento del desarrollo econômico. Rio de Janeiro: CEPAL/DOAT, 1960.

PROGRAMA DAS NAÇÕES UNIDAS PARA O DESENVOLVIMENTO - PNUD. Relatório de Desenvolvimento Humano 2002. http://www.undp.gov.br (18 ago. 2002)

ROBINSON, J.N. Técnicas de planejamento e previsão. Rio de Janeiro: Zaar, 1974.

ROBOCK, S.H. O desenvolvimento brasileiro em debate. Rio de Janeiro: Francisco Alves, 1977.

ROSSETTI, J.P. Política e programação econômica. 7.ed. São Paulo: Atlas, 1991.

SANDRONI, P. Novíssimo dicionário de economia. São Paulo: Best Seller, 2000.

SILVA, F.A.R. Avaliação do setor público na economia brasileira: estrutura funcional da despesa. Rio de Janeiro: IPEA, 1974. (Relatórios de Pesquisa) 
SILVA, L.M. Contabilidade governamental. São Paulo: Atlas, 1995.

SINGER, P. Desenvolvimento e crise. Rio de Janeiro: Paz e Terra, 1977.

TAVARES, M.C. Da substituição de importações ao capitalismo financeiro. Rio de Janeiro: Zahar, 1972.

TAVARES, M.C. Reflexões sobre o Estado e planejamento. Rio de Janeiro: IEI/UFRJ, jun. 1987. (Textos para Discussão, 154)

TAVARES, M. Repensando e refazendo o planejamento no Brasil. In: FORUM NACIONAL, 12., Brasília, 2000. VELLOSO, J.P.R. (Coord.). Brasil 500 Anos: futuro, presente, passado. Rio de Janeiro: José Olympio, 2000. p.187-193.

TINBERGEN, J. Programação para o desenvolvimento. Rio de Janeiro: Fundação Getúlio Vargas, 1969.

VARSANO, R.; AFONSO, J.R.; ARAÚJO, E.; PESSOA, E.; SILVA, N.; RAMUNDO, J.C. Uma análise da carga tributária do Brasil. Brasília: IPEA, ago. 1998. (Texto para Discussão, 583)

VASCONCELLOS, M.A.S.; GREMAUD, A.P.; TONETO, R. Economia brasileira contemporânea. São Paulo: Atlas, 1999.

WATERSON, A. Um método prático para planejar o desenvolvimento. Finanças e Desenvolvimento, v.3, n.1, p.10-14, 1970. 